\title{
CORPORATE DEFENSE LAW FOR DISPERSED OWNERSHIP
}

\author{
Nicholas L. Georgakopoulos*
}

\section{CONTENTS}

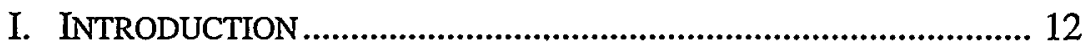

\section{OWNERSHIP DISPERSION AND MECHANISMS OF}

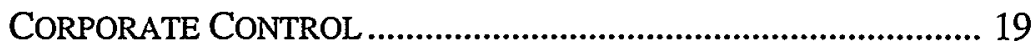

A. Locked Control .................................................................... 20

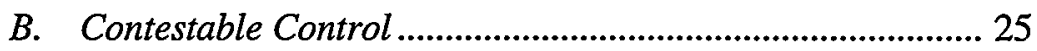

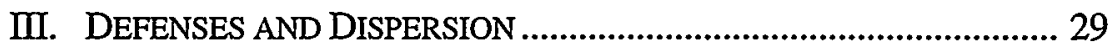

A. Delaware Attitudes: Difficult

Acquisitions from Dispersed Owners.................................. 30

B. Delaware's Neutrality to Dispersion-Preserving

Changes of Control: Easy Proxy Fights ................................ 49

C. European Attitudes: Easy Acquisitions from

Concentrated Owners

* Professor of Law, University of Connecticut School of Law; Visiting Professor of Law, Indiana University School of Law-Indianapolis; http://www.nicholasgeorgakopoulos.org. I wish to thank Michael Alexeev, John Armour, John Coates, Daniel Cole, Simon Deakin, Mitu Gulati, Henry Hansmann, Bob Heidt, Bob Lawless, J. Mark Ramseyer, Richard Ross, David Skeel, and Jeff Stake, for their invaluable comments; the audiences at the year 2000 annual meetings of the European Association of Law and Economics and of the Canadian Law and Economics Association; and Leo Plank for his guidance through and translation of the German tax reform of 2000.

I also wish to advertise the fact that the editing process of the Hofstra Law Review is the best that I have encountered so far, and by a wide margin; Steve Coran painstakingly pursued research that was relevant and complementary to the text while the Managing Editors and staff edited the text with cautious but not excessive respect. My thanks to them cannot be overstated. 
IV. WHY DISPERSED OWNERSHIP WITH SEMI-

ENTRENCHED CONTROL?

A. Dispersed Ownership with Semi-Entrenched

Control as a Precondition for the Vitality of the

Equity Markets

B. Defenses Provide a Superior Management

Contract

C. Solving the Collective Action Problem of

Adapting to Technological Change.

D. Market Attraction: Preserving Market Returns .................... 93

V. ARGUMENT SUMMARY AND NORMATIVE IMPLICATIONS.

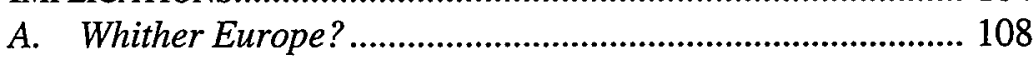

B. Whither America? ............................................................. 112

VI. CONCLUSION

\section{INTRODUCTION}

In the eyes of Hollywood and the press, hostile acquirers are personifications of evil. However, if we think of the great hostile acquirers of all ages, hostile acquirers with a long record of violence and predation are often treated better by history. The Roman Empire, Charlemagne, the Great Discoverers and the colonial expansion of the seagoing European powers, engaged in an enterprise very similar to hostile acquisitions. Each one observed resources that were underused because of the technological limitations of their controllers. The new user would take control of the resources, apply the new technology to them, and render them more productive. I must say that Rome's road and aqueduct technology increased the productivity of the resources of the Hellenistic society, despite some destruction of culture and the rollingin-graves of my distant ancestors. Charlemagne's governance pyramid of feudalism, as distasteful as it may seem in the hindsight of today's democratic and liberal reality, could be argued to be a superior governance technology for the conditions of those times. The colonial expansion of Europe was precisely the application of a multitude of superior technologies to otherwise underused resources.

These powers changed the world by accelerating growth. Imagine if the response, in each step, had been analogous to the building of the Great Wall of China. It is worth speculating about the shape of the world 
had the defenders succeeded in these and many other instances. Roman roads and aqueducts would not dot the Mediterranean, but more importantly, commerce, growth, and knowledge would not have propagated through the ancient world. Without Charlemagne, the Germanic tribes might have remained just that for quite some time. If the indigenous people of the Americas and the Far East had managed to turn away the colonial powers, many areas might still be in archaic stages of development and welfare. The advancement of knowledge for which we admire these hostile acquirers may be nothing loftier than a direct consequence of a quest for productivity.

The praise of historical hostile acquirers for material gains is countered by ire over violence, plunder, and destruction of cultural and social values. Perhaps the targeted societies could have done better if they had a defense system akin to modern corporate takeover defenses. They might have been able to implement new technologies and preserve their cultural, artistic, and social heritage, albeit at the cost of slowing the growth of material comforts. I will make an argument justifying takeover defenses that produce the same compromise. I will argue that the reduction of growth speed caused by defenses is justified from an economic perspective. Pursuing immediate productivity gains at all costs is a simplistic argument, but one that seems to have swept modern corporate scholarship.

This simplistic quest for productivity has led numerous academics to argue that defenses are undesirable, either altogether' or at least if they do anything more than facilitate the auction of the target corporation by its management. ${ }^{2}$ Investors, however, have refuted these arguments by consistently producing initial public offerings ("IPOs") of corporations that include defensive measures in their corporate fabric. ${ }^{3}$ Furthermore and very notably, shareholders prefer defenses over "golden

1. See frank H. Easterbrook \& Daniel R. Fischel, THE Economic Structure of CORPORATE LAW 196-98 (1991); Frank H. Easterbrook \& Daniel R. Fischel, The Proper Role of a Target's Management in Responding to a Tender Offer, 94 HARV. L. REV. 1161, 1195 (1981).

2. See, e.g., Ronald J. Gilson, A Structural Approach to Corporations: The Case Against Defensive Tactics in Tender Offers, 33 STAN. L. REV. 819, 867-70 (1981).

3. See laura Casares Field, Control Considerations in Newly Public Firms: The

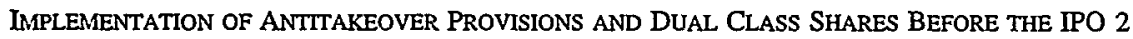
(Pa. St. Univ. Working Paper Series, 1999), available at http://papers.ssrn.com (last visited Dec. 30, 2001); JoHN C. COATES IV, EXPLAINING VARIATION IN TAKEOVER DEFENSES: FAILURE IN THE CORPORATE LAW MARKET 1-2 (Harvard L. Sch., L. \& Econs. Working Paper Series, Discussion Paper No. 297, 2000), available at http://papers.ssm.com (last visited Dec. 30, 2001); ROBERT DaINes \& Michael KLausner, Do IPO Charters MaXmize FiRM Value? ANTTTakeover PROVISIONS IN IPOS 4 (N.Y.U. Ctr. L. \& Bus., L. \& Econs. Working Paper Series, Working Paper No. 99-015, 1999), available at http://papers.ssm.com (last visited Dec. 30, 2001). 
parachutes," which compensate managers for being taken over. ${ }^{5}$ Thus compensated for losing their jobs, the managers' interests would align with those of shareholders. This Article, by finding several advantages in takeover defenses, explains these paradoxical contradictions between theory and practice. For the first time, defenses are shown to be socially desirable from an economic perspective in their own right, rather than a prevention of useless takeovers. ${ }^{6}$ Even previous studies that attempted to explain the popularity of defenses did not explain their use at the IPO stage, their supremacy over golden parachutes, or their social desirability.

4. Cf. Jeffrey N. Gordon, Ties That Bond: Dual Class Common Stock and the Problem of Shareholder Choice, 76 CAL. L. REV. 1, 17 (1988) (noting that the golden parachutes "may reduce shareholder wealth" because they "may reduce management's incentive to obtain the highest price for the shareholders").

5. See, e.g., BLACK'S LAW DictionARY 700 (7th ed. 1999).

6. In the law and economics family only Reinier Kraakman with Ron Gilson and John Coffee have pursued "discounted price" and "inefficient takeovers" as justifications of defenses, with little persuasion within the academy. See, e.g., Ronald J. Gilson \& Reinier Kraakman, Delaware's Intermediate Standard for Defensive Tactics: Is There Substance to Proportionality Review?, 44 BuS. LAw. 247, 267 (1989). Comparing the reception of that article in academia and the Delaware judiciary reveals the relative anti-defense bias of academia. The Gilson \& Kraakman article has been cited by 101 law review articles and has 7 citations in Delaware. Compare this 7 to 101 ratio of pro-defense scholarship with the 8 to 1828 ratio that anti-defense scholarship has. Searching for Easterbrook within four words from (w/4) Fischel produces 1828 law review articles, but only 8 Delaware cases, even though their articles start earlier and date from the early eighties. See generally Frank H. Easterbrook \& Daniel R. Fischel, Takeover Bids, Defensive Tactics, and Shareholders' Welfare, 36 BUS. LAw. 1733 (1981); Easterbrook \& Fischel, supra note 1. The searches were conducted on January 16, 2001, in Westlaw's law review database (identifier. JLR) and Delaware opinions (identifier: DE-CS).

7. Some argue that defenses entail negative externalities that explain their use but do not justify them from a social perspective. See generally LUCIAN ARYE BEBCHUK \& LUIGI ZINGALES, CORPORATE OWNERSHIP STRUCTURES: PRIVATE VERSUS SOCIAL OPTIMALITY (Nat'l Bureau of Econ. Research, Working Paper No. W5584, 1996), available at http://papers.ssm.com (last visited Dec. 30,2001$)$. The reduction of the pressure to produce short-term results is related to the arguments I make based on takeover threats due to low prices, but it depends on a fairly stylized set of verifiable and unverifiable information. See Lucian A. Bebchuk \& Lars A. Stole, Do Short-Term Objectives Lead to Under- or Overinvestment in Long-Term Projects?, 48 J. FIN. 719, 719 (1993). Other arguments explain defenses based on the private benefits of control, but those have not been elaborated so as to explain the variations from locks on control to strong and weak defensive structures. Ronen Israel and Qiang Ma formulate an argument that controllers, in response to the fear of a future takeover attempt, are biased in favor of risky long-term projects because they induce higher takeover prices and reduce the probability of a takeover. See generally RONEN ISRAEL \& QIANG MA, INVESTMENT HORIZON AND THE MARKET FOR CORPORATE CONTROL: THE DEFENSIVE ROLE OF LONG-TERM INVESTMENTS (Univ. of Mich., Interdisciplinary Ctr. Herzliya, Working Paper, 2000), available at http://papers.ssrn.com (last visited Dec. 30, 2001). Similarly, in "Breach of Trust" in Takeovers and the Optimal Corporate Charter, the author, Monika Schnitzer finds that the level of defenses chosen will deviate from the socially optimal. See Monika Schnitzer, "Breach of Trust" in Takeovers and the Optimal Corporate Charter, 43 J. INDUS. ECON. 229, 250-53 (1995). Fearing a takeover, the manager makes too little firm-specific investment and defenses allow the 
The contribution of this Article is the explanation of the function of corporate defenses. This explanation cures the stark contrast between theory and practice discussed above. Moreover, this thesis of defenses' desirability is bolstered by observed investor preferences. Investors choose defenses in transactions where managers do not have conflicting interests, such as at IPOs. Investors choose defenses compared to compensating managers for an increased risk of changes of control, such as by golden parachutes. Thus, this thesis is distinguished from explanations of the use of defenses that rely on a divergence of the managers' desire for entrenched control from the shareholders' desire for no defenses. If shareholders do not benefit from defenses, they can restrict management's ability to implement defenses. Even if the implementation of such restrictions in firms that are already public could be impeded by management, nothing explains the lack of restrictions on defenses at the moment of the IPO, when the revenues from selling shares to the public is directly determined by how attractive the corporation with its defenses is for public investors.

The contrast between the scholarship that considers defenses undesirable for shareholders, and the consistent practice of venture capitalists and entrepreneurs taking firms public after already equipping them with defenses, is sharpened by the lack of popularity of golden parachutes. Shareholders can compensate managers for giving managers indefensible ephemeral control. If shareholders preferred managers to have ephemeral control, and managers balked at the prospect of losing control in a hostile takeover, shareholders could compensate managers with golden parachutes, the lucrative severance clauses triggered by a change of control. ${ }^{8}$ Corporate practice, however, is not that of weak defenses and rich golden parachutes; it is the opposite: strong defenses and small golden parachutes.

manager to devote more to the firm, but weak defenses and golden parachutes are necessary to allow value-increasing takeovers. See id. at 252. The level of defenses and golden parachutes deviates from the socially optimal because shareholders benefit in the form of a higher premium by making a takeover more difficult. See id. at 253.

8. See BLACK's LAW DICTIONARY, supra note 5, at 700.

9. See, e.g., M.P. NARAYANAN \& ANANT K. SUNDARAM, A SAFE LANDING? Golden PARAChUTES AND CORPORATE BeHAVIOR 6 (Univ. of Mich. Bus. Sch., Working Paper Series, Working Paper No. 98015, 1998) (claiming that the opposition to golden parachutes is due to a fear that management will destroy corporate value in order to induce a takeover; showing that golden parachutes did not lead management to destroy corporate wealth but to take more desirable risks), available at http://papers.ssm.com (last visited Dec. 30, 2001); see also Jeffery A. Born et al., Golden Parachutes: Incentive Aligners, Management Entrenchers, or Takeover Bid Signals?, $16 \mathrm{~J}$. FIN. RES. 299, 305 (1993) (indicating that the adoption of golden parachutes after a furm is "in play" has no impact on price, suggesting no effect on the outcome of the contest; adoptions of golden 
Investors choose to have defenses because, contrary to previous academic commentary, defenses are good for investors for a long array of reasons. ${ }^{10}$ First, they facilitate financing. ${ }^{11}$ Defenses promote dispersed ownership by encouraging the reduction of controlling stakes. ${ }^{12}$ Dispersed ownership facilitates diversification and furthers market liquidity. ${ }^{13}$ Diversification reduces shareholders' exposure to risk with beneficial consequences. ${ }^{14}$ Shareholders' greater willingness to invest translates into a lower cost of capital for firms. ${ }^{15}$ Ownership by shareholders, who have neutralized their aversion to risk by being diversified, means that managers should run the firm in a risk-neutral way. Managers should not give up opportunities in order to avoid risk. Shareholders, moreover, provide managers with risk-taking incentivesas indeed they do by compensating managers with instruments such as options, that become more valuable as managers take more risks. ${ }^{16}$

parachutes by firms not "in play" produces increases; contrary to the authors' conclusion this shows that golden parachutes do induce firms to become "in play"); Lane Daley \& Chandra Subramaniam, Free Cash Flows, Golden Parachutes, and the Discipline of Takeover Activity, 27 J. Bus. Fin. \& ACCT. 1 passim (2000) (showing that the existence of golden parachutes leads to wasteful overinvestment occurring prior to a takeover); Wallace N. Davidson III et al., Golden Parachutes, Board and Committee Composition, and Shareholder Wealth, 33 FIN. REV. 17, 29 (1998) (showing that the market reaction to golden parachutes depends on the composition of the compensation committee of the board of directors; unaffiliated outsiders lead to gains supporting a beneficial alignment of interests with those of shareholders, an insider committee leads to price drops that support value-destruction); Ellie G. Harris, Antitakeover Measures, Golden Parachutes, and Target Firm Shareholder Welfare, 21 RAND J. ECON. 614, 623 (1990) (showing a theoretical model based on the premise that defenses enable target shareholders to extract a greater share of the surplus from corporate combinations; the prediction is that firms will give managers defenses to extract this surplus, but also golden parachutes, so as to insulate them against the loss of their jobs); Craig E. Lefanowicz et al., Golden Parachutes and Managerial Incentives in Corporate Acquisitions: Evidence from the 1980s and 1990s, 6 J. CORP. FIN. 215, 217-18 (2000) (studying two decades of defense use and golden parachutes, finding that they do induce more frequent takeovers); $L$. Mick Swartz, The Massachusetts Classified Board Law, 22 J. ECON. \& FIN. 29 passim (1998) (studying the imposition of a classified board by Massachusetts; all firms lost $16 \%$ of value on average, but firms with golden parachutes overcame the entrenching effect and outperformed their peers by 23\%).

10. The existing arguments only explain the use of defenses without justifying them. The argumentation is summarized in COATES, supra note 3, at 8-10, as defending against mispricing and attempting to retain private benefits of control.

11. See infra Part IV.A.

12. See infra Part IV.A.1.

13. See infra Part IV.A.3; see also John C. Coffee, Jr., The Future as History: The Prospects for Global Convergence in Corporate Governance and its Implications, 93 Nw. U. L. REv. 641, 648 n.24 (1999).

14. See infra Part IV.A.4; see also Jeffrey N. Gordon, Shareholder Initiative: A Social Choice and Game Theoretic Approach to Corporate Law, 60 U. CIN. L. REV. 347, 368-69 (1991).

15. See id.

16. The most readable introduction to options is in RONALD J. GILSON \& BERNARD S. Black, The Law and Finance of CoRporate ACQuisitions 231-50 (2d ed. 1995). A recent 
Dispersed ownership furthers market liquidity by producing large "floats" of traded shares. Large floats satisfy investors' demands for a vehicle in which to store their savings. Investors' trades attract informed speculators who, because of large floats, can profit from correcting prices. The resulting accurate prices further reduce investors' risk, increasing the attractiveness of the market and allowing firms to raise capital with less cost. Dispersed ownership is also inextricably entwined with potent legal protection for minority shareholders that reduces the discount of minority stakes compared to controlling stakes. Reduced minority discounts combine with takeover defenses to foster capital formation by making venture capital arrangements more attractive. The lack of deep discounts allows venture capitalists to disperse their controlling stake at an IPO instead of selling it as a controlling block, and allows entrepreneurs to credibly believe this will happen. Defenses enhance the value of the venture capital arrangement by assuring the entrepreneur to whom control reverts at the IPO that this control is not indefensibly ephemeral.

Defenses are also desirable because they add value to the managerial contract, a value that also drives some of the advantages for corporate financing mentioned above. The advantage of defenses for the managerial contract stems from the possibility of false takeovers, meaning takeovers that are not a result of managerial incompetence or a failure of the corporate strategy. ${ }^{17}$ This is because share prices may be unduly low, either despite an accurate valuation by the market or because of inaccurate pricing. Share prices can be accurately depressed in anticipation of corporate choices among alternative strategies. Share prices can be falsely depressed, despite the evidence of market efficiency, because the evidence regards averages rather than proving the accurate valuation of each firm. Protection against false takeovers would

empirical confirmation that options are more effective at inducing risk-taking than grants of stock is in Stephen Bryan et al., CEO Stock-Based Compensation: An Empirical Analysis of IncentiveIntensity, Relative Mix, and Economic Determinants, 73 J. Bus. 661, 664-70 (2000) (comparing options and restricted stock as managerial compensation devices).

17. This justification of defenses bears a distant relation to Ron Gilson's justification of dual class capitalization structures for hard-to-value firms with growth potential in Ronald J. Gilson, Evaluating Dual Class Common Stock: The Relevance of Substitutes, 73 VA. L. REV. 807 (1987). According to Gilson, the difficulty of valuation justifies a lock on control, lest an undeserving buyer acquire the firm and put its assets in a wasteful use. See id. at 811. If we follow my argument here, however, we see that Delaware law produces a superior outcome by allowing managers to defend their control. See infra Part III. The superiority lies in the enhancement of the equity markets due to the dispersed ownership and, even more importantly, due to the fact that the market for control still exerts its disciplining effect on management. Of course, a dual class recapitalization would give management a lock on control and would imply a loss of this disciplining effect. 
not have value if managing a private corporation or a subsidiary were equivalent to heading a public firm. Heading a public firm is vastly different because the chief's tenure depends not on the opinion of a single boss, but on the consensus of the market, which has an effect equivalent to a diversification of the evaluators of the chief's human capital.

Defenses are also desirable because, by temporarily protecting management, they grant management the luxury of delaying the implementation of new technology. In the case of radical new technologies, this otherwise wasteful delay may be socially desirable because it alleviates the retraining bottleneck. Retraining to use new technology is a social problem because the general use of the new technology implies that it is a general and transportable skill that firms will not provide.

Finally, defenses are not as costly ex ante as the ex post takeover premiums indicate. Takeovers subject investors to a host of tax disadvantages, to express and implied transaction costs, and to the adverse selection problem of buyout firms removing the most attractive firms from public investors' diversified portfolios ("cherry picking").

Part II of this Article describes the different mechanisms of control. The variation is very large, but it reveals a range of safety of control. Majority ownership or pyramid holding structures, for example, allow a lock on control. If ownership is dispersed, however, the permanence of control depends on the strength of takeover defenses, ranging from ephemeral control to entrenched control, with Delaware law providing an interesting middle ground of semi-entrenched control.

Part III examines how defense law influences dispersion of ownership. Part III.A reveals the permissive attitude of Delaware courts regarding defenses. Part III.B shows that Delaware courts make an about-face when the threat to control does not involve the potential to concentrate ownership. Pure proxy fights-that are not accompanied by a tender offer-do not allow similarly powerful defenses by management. Part III.C looks at the European experience. Despite the slower and more decentralized legal developments, defenses of an intensity similar to those used in the United States are unlikely to be sanctioned in Europe. The crucial difference is that European targets have a more concentrated ownership structure while acquirers may offer a chance to induce more dispersed ownership. Thus, legal systems on 
both sides of the Atlantic seem to aim for the same substantive result, of either preserving or inducing dispersed ownership. ${ }^{18}$

Part IV of this Article examines the benefits of dispersed ownership and of defenses in the context of the U.S. tax and capital market system. While defenses preserve the vitality of equity markets by preserving a large publicly traded float of shares, they also provide strong incentives for founders to take their firms public, and support venture capital arrangements. These are preconditions for liquid and efficient markets. Defenses also prevent accidental replacement of efficient management at times of temporarily low prices. Dispersed ownership and defenses also produce dynamics which induce gradual retooling in the face of technological change. Thus, they alleviate the retraining bottleneck that would be induced by firms that, subject to concentrated ownership and hostile acquisitions, would rush to implement new technology. Dispersed ownership and defensive tactics, therefore, mitigate the costly shocks of transitioning to new methods of production. Finally, defenses prevent tax and transaction cost burdens that hostile takeovers would place on investors, indicating that their cost is not as large as hostile premiums.

Part V reflects on the interaction of the above arguments. Optimal defense intensity depends on three factors. It depends on ownership dispersion, on the expected speed of technological change, and on the quality of the equity markets. These conclusions allow an evaluation of various aspects of United States and European Union defense law.

\section{OWNERSHIP DISPERSION AND MECHANISMS OF CORPORATE CONTROL}

Control can either be locked or contestable. Locked control means that the control of the firm is determined with certainty in that no

18. Professor John $\mathrm{C}$. Coffee has made a related point by arguing that, while the corporate governance systems of different jurisdictions may not be converging in terms of their rules, the outcomes they produce are converging in function because of the practices of firms, such as their choices regarding in what exchanges to list their shares for trading. See Coffee, supra note 13, at 679,681 . The convergence I analyze in this Article regards the outcome of dispersed ownership. In legal systems that produce immediate creation of dispersed ownership, such as the United States and the United Kingdom, arming managers with defenses preserves the dispersed ownership that these systems amply produce. Legal systems that fail to directly produce dispersed ownership may hope to induce some dispersion by means of hostile acquisitions, because some may be conducted by dispersed acquirers. Thus, the functional convergence of dispersed ownership is induced by divergent rules. Note that to the extent that the European attitudes are actually motivated by a desire to induce dispersed ownership, their strategy is criticized below. See infra Parts III.C., V.B. 
insurgent group of shareholders can gain control of the corporation. ${ }^{19}$ If the possibility exists, however remote, that insurgents may gain control, then control is contestable. ${ }^{20}$ Before examining the variations of contestable control, a closer look at the types of locked control is needed.

\section{A. Locked Control}

Locked control results from the entrepreneur's desire not to risk losing control. The countervailing force is the ability to diversify. The entrepreneur's financial risk can be reduced dramatically by shifting wealth to other investments. The great impetus for maintaining control is that it has value. The value of control depends partly on the quality of protection that the legal system provides to minority shareholders. If minority shareholders are adequately protected from managerial abuse, control loses the value it has due to its potential to abuse minority shareholders. Three mechanisms allow entrepreneurs to maintain a lock on control: retaining majority ownership of the firm's common stock; having dual class capitalization with different voting powers, thus retaining voting control without majority; and creating pyramid holding companies in which control of a parent corporation leads to control of an ultimate subsidiary several layers below. These mechanisms are explored below.

\section{Majority Ownership}

The conventional way of retaining a lock on control is majority ownership. Without any unusual holding structures or voting powers, the entrepreneur simply retains a majority of the common stock. In annual director elections, the entrepreneur's votes elect the directors who run the corporation. ${ }^{21}$

Limitations are imposed by a drive to retain majority control. As the firm raises capital, it may issue stock, but only to the point where the founder's block of stock is reduced to a bare majority. As the firm makes acquisitions, it can use its stock as consideration, but again, only so far

19. See Peter Moles \& Nicholas TerRy, The HANDBOOK of INTERnational Financial TERMS 110 (1997).

20. See id.

21. See Clifford G. Holderness \& Dennis P. Sheehan, Constraints on Large-Block Shareholders, in CONCENTRATED CORPORATE OWNERSHP 139, 146-47 (Randall K. Morck ed., 2000); Arthur R. Pinto, Section III: Corporate Governance: Monitoring the Board of Directors in Corporate Governance, 46 AM. J. COMP. L. 317, 344 (1998) (discussing problems with controlling shareholders in the election of directors). 
as the founder's block does not get diluted below absolute majority. These limitations on raising capital and on the form of corporate combination transactions are very significant.

Even more significant is the fact that ownership of an absolute majority implies an enormous investment in the firm for the founder in the case that the firm is successful. This also implies that the founder's exposure to firm-specific risk is very large. The size of this exposure is clearer if we compare it with the founder's risk if the founder could move some of this wealth to other investments, a move that would diversify the founder's portfolio and partially insulate it against risks idiosyncratic to the founder's firm.

A real world example illustrates the size of the risks that a majority owner runs. Consider IBM's strategic refocusing in the early nineties in response to the switch of the computer market from mainframes to personal computers. ${ }^{22}$ IBM now has about 1.76 billion shares outstanding and, adjusted for stock-splits, had reached a pre-1992 high price of about $\$ 44$ in $1987 .^{23}$ In late 1993 and early 1994 its price had tumbled to well below $\$ 15$. $^{24}$ If IBM had a $51 \%$ stockholder, the price drop would correspond to a reduction in wealth of at least $\$ 26$ billion, a drop roughly equivalent to Bill Gates's wealth at that time.

The enormity of the entrepreneur's risk is of little direct concern for society, other than for the fact that it provides the desirable incentive to diversify and disperse the corporation's ownership. Society cares about productivity and the productivity incentives of such a large and littlediversified stake in a single firm. Those push the founder toward riskaverse management of the firm, and create a bias toward obtaining diversification through the firm's activities rather than through alternative investments. For example, the founder can obtain diversification through the firm's activities in various ways: through internal expansion, through retention of business lines that might be

22. See Ira Sager, It's Hot! It's Sexy! It's . . . Big Blue?, Bus. WK., Mar. 4, 1996, at 39, 39.

23. The calculation in the text is probably an underestimation, because IBM has been on extensive stock repurchase programs since the late eighties. The repurchases suggest that IBM had more shares outstanding during this drop in price, so that its effect was much larger than this estimate. The number of outstanding shares was obtained from MARKET GUIDE, MARKET GUide/Provestor Plus COMPANY REPORT: IBM 2 (Oct. 6, 2000), available at http://www.iulaw.indy.indiana.edu/instructors/georgakopoulos/prof/ProvestorIBM.pdf (last visited Feb. 22, 2000).

24. See Stock Charting for Intemational Business Machines Corp., WALL ST. J. (Sept. 30, 2001), at http://www.bigcharts.com/custom/wsjie/public-charting.asp? (last visited Sept. 30, 2001). 
productively separated from the rest of the firm, and, generally, through wasteful conglomeration. ${ }^{25}$

Internal diversification is common. The most vivid example of such strategies of diversifying through the activity of the controlled company can be found in the Japanese and Korean family groups, the pre-World War II zaibatsu ${ }^{26}$ (precursors of the keiretsu) and the chaebol. ${ }^{27}$ For example, the Mitsubishi Group has over forty major corporations (which regrouped after the original family of affiliated corporations was split during the U.S. occupation into 139 companies) $;^{28}$ and the Mitsui Group has over 880 subsidiaries and associated companies (after a split during the occupation into more than 200 companies). ${ }^{29}$ The families behind the Mitsubishi and Mitsui zaibatsu were not exposed to the same risk as they would have been if their entire wealth were exclusively invested in a single one of these firms.

25. Recent evidence on conglomeration shows that conglomerates allocate capital to the divisions that face inferior opportunities instead of allocating their resources where the greatest opportunities lie. See Raghuram Rajan et al., The Cost of Diversity: The Diversification Discount and Inefficient Investment, 55 J. FIN. 35, 45-48 (2000).

26. The keiretsu are groups of firms that have informal understandings rather than the strong common ownership and cross-ownership of the zaibatsu, which the United States dissolved after World War II. See Evolution of Keiretsu and Their Different Forms, at http://www.mgmt.utoronto.ca/ baum.mgmt2005/keiretsu.htm (last visited Sept. 29, 2001). For a recent recounting of the attempt to break up the zaibatsu and the reconstitution of the Mitsubishi, Mitsui, and Sumitomo groups in new quasi-zaibatsu, see Andrew H. Thorson \& Frank Siegfanz, The 1997 Deregulation of Japan's Holding Companies, 8 PAC. RIM L. \& POL'Y J. 261, 270-73 (1999); see also W. CARL Kester, JAPANESE TAKeovers: THE Global CONTEST for CORPORATE CONTROL 54-55 (1991); Erik Berglöf \& Enrico Perotti, The Governance Structure of the Japanese Financial Keiretsu, 36 J. FIN. ECON. 259, 260 (1994); Michael Bradiey et al., The Purposes and Accountability of the Corporation in Contemporary Society: Corporate Governance at a Crossroads, 62 LAW \& CONTEMP. PROBS. 9, 57 \& n.283 (1999) (collecting sources for additional details on the Japanese keiretsu); David Flath, Shareholdings in the Keiretsu, Japan's Financial Groups, 75 REV. ECON. \& STAT. 249 passim (1993); Hesna Genay, Japan's Corporate Groups, ECON. PERSP. Jan.-Feb. 1991, at 20, 20-23; Ronald J. Gilson \& Mark J. Roe, Understanding the Japanese Keiretsu: Overlaps Between Corporate Governance and Industrial Organization, 102 YALE L.J. 871, 899 (1993); James R. Lincoln et al., Evolving Patterns of Keiretsu Organization and Action in Japan, 20 RES. ORG. BEHAV. 303, 311-14 (1998); James R. Lincoln et al., Keiretsu Networks and Corporate Performance in Japan, 61 AM. SoC. REv. 67, 7172 (1996).

27. See Kwang-Rok Kim, Korean Hostile Takeovers and the Friendly Internationalization of the Securities Market: An Investor Protection Perspective, 10 MINN. J. GloBAL TRADE 357, 368 (2001).

28. See Hoover's Company Profile Database, World Companies, Mitsubishi Group, available at LEXIS, Market \& Industry Library, Directories (2001).

29. See Hoover's Company Profile Database, World Companies, Mitsui Group, available at LEXIS, Market \& Industry Library, Directories (2001). 
2. Dual Class Voting

Founders, however, can reduce their stakes to below majority and retain a lock on control if their firms can offer different classes of stock with different voting powers. ${ }^{30}$ The ultimate example would have firms issue stock without any voting rights to the public and allow founders to retain all or a majority of the voting stock. ${ }^{31}$ Such a maneuver would allow the founders' wealth to be separated from the firm, since the size of the voting class of stock can be arbitrarily small. Thus, dual class voting would allow the entrepreneur to retain a lock on control with an arbitrarily small investment. Founders can convert the rest of their stock into nonvoting stock and sell to the public, thus diversifying their wealth and losing the undesirable incentives for risk-averse management and conglomeration.

This advantage of dual class voting is very large, and when the legal environment allows it, dual class voting will be the preferred method of retaining a lock on control. Nevertheless, locked control through dual class voting does have undesirable ramifications, but it shares those mostly with the next form of maintaining a lock on control, pyramid groups.

\section{Pyramid Groups}

If founders cannot release wealth from the firm by means of dual class voting, they may still be able to reduce their exposure by creating a pyramid holding structure. The pyramid works by having layers of holding companies, each owning $51 \%$ of the next, the last one of which owns $51 \%$ of the operating company. ${ }^{32}$ The $49 \%$ of each layer of holding company is sold to outside investors, and the founder can have a lock on the control of the operating company with a very small investment in the ultimate parent corporation. ${ }^{33}$ An example of a pyramid structure with three holding company layers will make the function of the pyramid obvious.

Suppose the operating company is worth $\$ 100$ million. A $51 \%$ stake in it would imply that $\$ 51$ million of its founders' wealth would have to be tied up in the firm. The creation of a holding company relaxes this constraint. A first parent company can be created to own the $51 \%$ controlling stake in the operating company. This first parent allows the

30. See Gordon, supra note 4, at 3, 10.

31. See id. at 74 .

32. See, e.g., AleXANDER H. FReY ET al., CASES AND Materials on CoRporations 398 (2d ed. 1977).

33. See id. 
founders to control the operating company with $51 \%$ in this first parent. Since the first parent's assets are $\$ 51$ million, the founders' stake is worth $51 \%$ of $\$ 51$ million, or $\$ 26.01$ million. A second layer holding company will allow the first parent to be controlled with a $51 \%$ in this second parent, which involves an investment of $\$ 13.27$ million. A third holding company reduces the investment necessary to maintain a lock on control even further to $\$ 6.77$ million.

The reduction of financial exposure to risk that founders can obtain by means of either a pyramid or dual class is not costless. Since the drive to retain control is partly motivated by the legal system's failure to adequately protect minority shareholders, the noncontrolling stakes that are sold through either scheme are valued at a discount by their buyers. The estimates of such discount range from 5\% in the United States to over $80 \%$ in other leading Western jurisdictions. ${ }^{34}$ Even if the buyers are paying exactly the value of what they are receiving, the selling of the minority stakes creates the appearance that the entire enterprise is being discounted and creates a paper loss for the entrepreneur.

If, for example, the enterprise is worth $\$ 100$ million, $\$ 20$ million of which is the value of control, the noncontrolling shares being soldminority shares in the case of pyramids, weak or nonvoting shares in the case of dual class stock - are shares in an $\$ 80$ million asset, the business without control. The greater a fraction of the control-denuded business that the entrepreneur sells, the stronger the appearance that the entrepreneur is accepting $\$ 80$ million for an asset worth $\$ 100$ million. If this entrepreneur's stake is reduced to $10 \%$, the appearance is created that the entrepreneur's stake in the firm is worth $\$ 8$ million, because the $\$ 20$ million value of control is not denominated. Depending on the circumstances, entrepreneurs may find such an appearance undesirable. For example, the undenominated value of control would not serve as collateral for financing.

Creative corporate planning may be able to allow the founders of large firms to shield large parts of their wealth from their firms' risk, but

34. See Luigi Zingales, The Value of the Voting Right: A Study of the Milan Stock Exchange Experience, 7 REV. FIN. STUD. 125 passim (1994) (stating the Milan average control premium of $86 \%$, world average $10 \%$ to $20 \%$, U.S. premium about $5.24 \%$ ); see also MARTIN HOLMÉN \& PETER HÖGFELDT, A LAW AND FINANCE ANALYSIS OF INITIAL PUBLIC OFFERINGS 1 (2001), available at http://papers.ssrn.com (last visited Dec. 30, 2001); TATIANA NENOVA, THE VALUE OF CORPORATE VOTES AND CONTROL BENEFITS: A CROSS-COUNTRY ANALYSIS 3-4 (Harv. Univ., Working Paper Series, 2000) (estimating the value of control in Brazil, Chile, France, Italy, Mexico, and South Korea between a quarter and a half of a firm's capitalization, while the value of control in common law and Scandinavian countries is under $10 \%$, and the value of control in the United States and several other countries is under 4\%), available at http://papers.ssrn.com (last visited Dec. 30, 2001). 
not without cost. ${ }^{35}$ Moreover, founders will still have risk-aversion and conglomeration incentives because they would still retain a very significant investment in the firm. Thus, dual class voting and pyramids may well alleviate, but by no means do they eliminate, the principal undesirable consequences of having a lock on control. Locked control, in all its forms, has disadvantages for society. These exceed the lack of diversification which leads to risk-averse management and conglomeration. The drawbacks of locked control are principally the tendency toward nepotism, and the undermining of the venture capital arrangement. $^{36}$

Nepotism is a natural consequence of a lock on control. The founders' family takes control as a matter of the intergenerational passing of wealth. This is, of course, contrary to the social interest of control passing on a meritocratic basis. Recent evidence from Sweden illustrates pointedly this effect: the minority discount in cases where subsequent generations are in control is much greater than the discount when the founder is still in control. ${ }^{37}$

\section{B. Contestable Control}

When it is at all possible for an outsider to obtain control of the corporation, the control is contestable..$^{38}$ Contrary to locked control, contestable control implies some risk for the controller that control may be lost, but that risk varies from significant to trivial. The variation is not only due to market circumstances that may make large purchases prohibitively expensive, for example, through lack of liquidity, or that may, through poor communications, hamper attempts to organize a dissenting group. The variation in the contestability of control comes in large part from the legal system, most pertinently, the law regarding the defensive measures that the target management can use to fend off an acquirer.

Contestability is determined by the intensity of defensive measures that the target corporation's board of directors can implement without a

35. See HOLMÉN \& HöGFELDT, supra note 34 , at 7.

36. See infra Parts IV.A.1 \& IV.A.5. For the dynamics of the implicit commitments in the venture capital arrangement, see, for example, Joseph Bankman \& Ronald J. Gilson, Why Startups?, 51 STAN. L. REv. 289, 299-301 (1999); Erik Berglöf, A Control Theory of Venture Capital Finance, 10 J.L. ECON. \& ORG. 247, 248 (1994); Lisa Bernstein, The Silicon Valley Lawyer as Transaction Cost Engineer?, 74 OR. L. Rev. 239, 248-50 (1995).

37. See Holmén \& HöGFelDT, supra note 34, at 5.

38. See, e.g., John C. Coates IV, Team Production in Business Organizations: Measuring the Domain of Mediating Hierarchy: How Contestable Are U.S. Public Corporations?, 24 IOWA J. CORP. L. 837, 849-50 (1999). 
shareholder vote. ${ }^{39}$ Potent defenses would require various measures: issuance of new securities, the rights of which may be contingent on control events; the offering of new classes of stock, with potentially superior voting powers; varying the voting rights of existing securities; triggering contingent voting rights of previously issued securities; or creating corporate liability to friendly shareholders, that is perhaps contingent on control events. Other defensive mechanisms would interfere with the electoral process and prevent or delay shareholder votes or director nominations, or extend the terms of the current directors. Many of these actions may contradict the basic premises of a legal system's corporate law and others may not be expressly within the board's powers. Legal systems vary from expressly prohibiting defensive measures to expressly creating defensive capacity.

Although contestability is a question of degree, there are three important segments along its spectrum, which are classified by the risk to control that they pose. The complete absence of defenses produces maximum contestability and ephemeral control. Entrenched control is the extreme opposite-extraordinary defenses and little contestability. A strikingly successful middle ground is that produced by mediumintensity defenses, which produce semi-entrenched control-control that is not ephemeral but, unlike entrenched control, is realistically contestable.

1. Ephemeral Control: United Kingdom

"Ephemeral control", is produced by rules which prevent management, acting through the board of directors, from using any defensive measures. The prime example is Rule 21 of the British City Code on Takeovers and Mergers which prohibits all defensive measures once a hostile offer is imminent. ${ }^{42}$ Rule 21 applies through selfregulation to listed corporations in the United Kingdom. ${ }^{43}$

39. See id.

40. See HOLMÉN \& HöGFELDT, supra note 34 , at 6 .

41. Control is "ephemeral" when it is essentially "transient" and has "no lasting significance." MERRIAM-WEBSTER's COLlEGIATE DictionARY 388-89 (10th ed. 1996) (defining "ephemeral"); see also Ronald H. Jensen, Of Form and Substance: Tax-Free Incorporations and Other Transactions Under Section 351, 11 VA. TAX REV. 349, 372 (1991) (stating that when applying the "step transaction doctrine," the courts have "acted as 'hard-headed realists' who are not going to be duped by a fleeting, ephemeral control' (emphasis added)).

42. See Bernard Black \& Reinier Kraakman, A Self-Enforcing Model of Corporate Law, 109 HARV. L. REV. 1911, 1962 (1996).

43. See PANel on TAKeovers and Mergers, City Code on TaKeovers and Mergers R. 21 (1985), available at http://www.thetakeoverpanel.org.uk (last visited Feb. 6, 2002). It is applicable only to publicly traded corporations ("listed corporations") with contestable control. 
The result of management's inability to erect defenses means that a hostile offer will reach the shareholders. Whether this is a hostile offer to purchase enough shares to promote the acquirer's stake into majority or an insurgent shareholder's nomination of alternative directors and the invitation to other shareholders to vote for them, the besieged board of directors cannot interfere. The contest may be lost as soon as enough shareholders sell or at the time shareholders vote. Control will at that time pass to the hostile suitor. The inability of the target's controller to stop the suitor, makes control ephemeral.

\section{Entrenched Control}

The opposite extreme to ephemeral control is produced by legal systems which provide managers with ammunition to avoid changes of control. When the defensive measures are strong enough, change of control can be delayed or thwarted. ${ }^{44}$ Indiana, for example, has enacted a statutory provision denuding hostile buyers of their shares' votes indefinitely; only an affirmative vote by a supermajority of the minority can restore the purchaser's votes, and bestow control on the purchaser. ${ }^{45}$ After Indiana's provisions withstood a constitutional challenge, ${ }^{46}$ twentyfive more states created similar control share acquisition statutes ${ }^{47}$ and

See id. Control contests can arise in corporations whose stock is not publicly traded. Those contests will involve closely held corporations which engender an entirely different set of relations between its shareholders and the corporation. Thus, little functionality is lost because Rule 21 is limited to listed corporations. Rule 21 does imbue the decision of a corporation to go public with a defensive quality. Remaining private, even if the minority stake is fairly broadly dispersed, would preserve the defensive capacity of the board.

44. See COATES, supra note 3 , at 5 .

45. See IND. CoDE ANN. \$ 23-1-42-9 (West 1989). Corporations can elect in their charter or bylaws not to be subject to this defensive measure. See id. $\S 23-1-42-5$. The acquisition threshold is $20 \%$. See id. § $23-1-42-1(1)$.

46. See CTS Corp. v. Dynamics Corp. of Am., 481 U.S. 69, 93 (1987).

47. Only Hawaii limits the time during which the acquired shares do not have voting rights, while twenty-five states remove voting powers indefinitely (but Arizona and Nebraska allow the voting in director elections only). See ARIZ. REV. STAT. ANN. § 10-2725(A) (West 1996) (retaining voting power for election of directors and no other matter); FLA. STAT. ANN. $\$ 607.0902(9)(a)$ (West 2001); HAW. REV. STAT. \$ 415-172(b) (1993) (mandating no voting and no transferability for one year from acquisition); IDAHO CODE \$30-1607(1) (Michie 1999); KAN. STAT. ANN. $\S 17-1294(\mathrm{~b})(1)$ (2000); LA. REV. STAT. ANN. $\$ 12: 140$ (A) (West 1994); MD. CODE ANN., CORPS. \& ASS'NS § 3-702(a)(1) (Supp. 2000); MASS. GEN. LAWS ANN. ch. 110D, § 5 (West 1999); MICH. COMP. LAWS ANN. \$ 450.1794 (West 1990); MINN. STAT. ANN. \$ 302A.671(1)(b) (West Supp. 2001); MISS. CODE ANN. § 79-27-7 (1999); MO. ANN. STAT. § 351.407(5)-(1) (West 1991); NEB. REv. STAT. ANN. \$21-2451 (Michie 1999) (Nebraska, like Arizona, allows voting on director elections only); NEv. REv. STAT. ANN. § 78.379 (Michie 1999); N.C. GEN. STAT. \$ 55-9A-01 (1999); OHIO REV. CODE ANN. $\$ 1701.831$ (A) (Anderson 2001) (making purchase conditional on approval); OKLA. STAT. ANN. tit. 18, \$ 1149(1) (West 1999); OR. REV. STAT. $\$ 60.807$ (1999); 15 PA. Cons. STAT. ANN. \$2564(a) (West 1995); S.C. Code ANN. $\$ 35-2-109$ (a) (Law. Co-op. 
over forty more have some state antitakeover protection. ${ }^{48}$ Other measures with defensive character are also available, such as the obligation on the acquirer to buy all minority shares at a "fair value" that can be defined by the target corporation beforehand and cannot be lower than the highest price that the acquirer has paid per share. ${ }^{49}$ Pennsylvania, for example, in addition to its control share statute, ${ }^{50}$ forces disgorgement of greenmail and short-term control premiums, and gives terminated employees and collective labor contracts special protection. ${ }^{\text {s1 }}$ Delaware does not adopt these most entrenching versions of defenses, but does restrict mergers for three years after a hostile acquisition. $^{52}$

Measures such as the control share acquisition statutes are draconian. They render the risk to control trivial. Control is so safe that it is entrenched.

\section{Semi-Entrenched Control: Delaware}

Delaware does give managers defensive powers, but not quite to the same extent as Indiana and other states with control share statutes. Delaware limits the amount of time during which hostile acquirers'

Supp. 2000); S.D. CODIFIED LAwS § 47-33-8 (Michie 2000); TENN. CODE ANN. § 48-103-307 (1995); UTAH CODE ANN. § 61-6-10 (2000); VA. CODE ANN. § 13.1-728.3 (Michie 1999); WIS. STAT. ANN. $\S 180.1150$ (b)(2) (West 1992 \& Supp. 2000) (limiting control shares to $10 \%$ of their normal voting power); WYO. STAT. ANN. $\$ 17-18-306$ (Michie 2001).

The drafting of the Model Control Share Act is discussed in Evan M. Kjellenberg, The Model State Control Share Act: The Best State Takeover Law Altemative, 8 N. ILL. U. L. REv. 329, $338-41$ (1988). The political economy of the adoption of control share acquisition statutes is discussed in William J. Carney, The Political Economy of Competition for Corporate Charters, 26 J. LEGAL STUD. 303, 321-23, 328 (1997), and William J. Camey, The Production of Corporate Law, 71 S. CAL. L. Rev. 715, 735-36 (1998).

48. See Joseph A. Grundfest, Just Vote No: A Minimalist Strategy for Dealing with Barbarians Inside the Gates, 45 STAN. L. REV. 857, 861 nn.9-10 (1993) (providing a comprehensive list of citations).

49. See, e.g., IND. CODE ANN. $\S 23-1-44-8$ (West 1989). Other states that give dissenters such a right to "fair value" are Florida, Louisiana, Michigan, Mississippi, Oregon, South Carolina, Virginia, and Wyoming. See FlA. STAT. ANN. \$607.1302 (West 2001); LA. REV. STAT. ANN. $\S 12: 131(\mathrm{C})(2)$ (West Supp. 2001); MICH. COMP. LAwS ANN. $\$ 450.1762(1)$ (West Supp. 2001); MiNN. STAT. ANN. § 302A.471(1) (West Supp. 2001); Miss. CODE ANN. § 79-4-13.02(a) (1999); OR. REV. STAT. \& 60.813 (2000); S.C. CODE ANN. § 33-13-102 (Law. Co-op. Supp. 2000); VA. CODE ANN. § 13.1-728.8 (Michie 1999); WYO. STAT. ANN. § 17-18-308 (Michie 2001).

50. See 15 PA. CoNS. STAT. ANN. § 2564 (West 1995).

51. See id. $\$ 2575$ (disgorging short-term profits of new control groups and making them recoverable by the corporation); id. $\$ 2582$ (providing severance for terminated employees); id. $\$ 2587$ (preserving labor contracts).

52. See DEL. CODE ANN. tit. 8, § 203(a)-(b) (Supp. 2000) (allowing the corporation to opt out via amendment to either the certificate of incorporation or the bylaws). 
rights are restricted-no merger for three years ${ }^{53}$-and allows corporations to opt out of defenses if they wish. ${ }^{54}$ The shape of Delaware defense law will be examined in detail in the next section, but the results for the controller are clearly intermediate. Control is safe enough not to be ephemeral, but not so safe as to be entrenched. Thus, this brand of contestability can be appropriately called semi-entrenched control.

This feature of Delaware law will be apparent in Part III. The principal purpose of Part III is to show how the law of Delaware and of some European jurisdictions promotes dispersed ownership. Part IV returns to the quest for optimal defense intensity. Not surprisingly, neither extreme is optimal. The extreme safety of defenses that produce entrenched control eliminates the disciplining effect of the market for control. The extreme risk of no defenses produces ephemeral control and has a host of ill effects for the firm and society.

\section{DEFENSES AND DISPERSION}

Dispersed ownership and contestable control arose much before merger and acquisition law developed the sophistication it has today. The conventional view is that the principal feature that promotes dispersed ownership and contestable control is the protection of minority shareholders. ${ }^{55}$ While this cannot be disputed, the importance of takeover defenses cannot be denied. Defense law is inextricably bound with entrepreneurs' and financiers' incentives to create, finance, and take companies public. ${ }^{56}$ Defense law, which determines the value and the control rights of equity securities, ${ }^{57}$ is a consideration in every transaction and decision that might lead to public stock offerings. These indirect incentives are generic and attach to any form of defense law. This section will examine various legal systems for more direct evidence of the relation between dispersed ownership and defense law. Not

53. See id. § 203(a).

54. See id. § 203(b).

55. The Asian crisis has provided quantifiable evidence of the importance of minority protection. Jurisdictions with worse shareholder protection experienced greater drops in prices. See Simon Johnson et al., Corporate Governance in the Asian Financial Crisis, 58 J. FIN. ECON. 141, 184-85 (2000). For a general discussion of the discount of minority shares and corporate law, see John C. Coates IV, "Fair Value" as an Avoidable Rule of Corporate Law: Minority Discounts in Conflict Transactions, 147 U. PA. L. REV. 1251, 1273-77 (1999).

56. See generally Stephen Mahle, Proxy Contests, Agency Costs, and Third Generation State Antitakeover Statutes, 15 J. CORP. L. 721, 728-31 (1990) (discussing the rationale behind antitakeover laws).

57. See Henry N. Butler, Corporation-Specific Anti-Takeover Statutes and the Market for Corporate Charters, 1988 WIS. L. REV. 365, 376-77. 
surprisingly, such evidence exists on both sides of the Atlantic. In the United States's predominant corporate forum, Delaware, the availability of defenses in some types of transactions depends on the ownership dispersion of the corporations that are involved. After the extensive analysis of Delaware law in the next section, Europe appears relatively insensitive to dispersion, but the analysis in Part III.C will show an implicit relation between defense law and dispersed ownership in Europe.

\section{A. Delaware Attitudes: Difficult Acquisitions from Dispersed Owners}

During the gradual rise in the frequency of hostile takeovers, the Delaware courts did not expressly distinguish between hostile threats that would concentrate ownership and hostile threats that would not. ${ }^{58}$ This distinction would eventually rise in prominence. Even in the early cases, however, the courts displayed sensitivity to threats that would concentrate ownership. In fact, the Delaware courts had already addressed dispersion when they dealt with greenmail.

\section{Pivotal Choice}

\section{a. Greenmail}

The first break with conventional corporate law came when corporate management tried to buy the friendship of threatening shareholders. ${ }^{59}$ Giving corporate assets to a shareholder for no apparent consideration is problematic. It contradicts the classic principle of corporate law that assets go to the shareholders proportionately. ${ }^{60}$ One could easily argue that this so-called "greenmail" payment to a shareholder in exchange for what has come to be known as a "standstill agreement" ${ }^{\prime \prime 1}$ is no different than a dividend that discriminates among shareholders, awarding more value to some for unverifiable and evanescent reasons. Basic corporate law ensures the even division of corporate wealth among shareholders. ${ }^{62}$ The long stream of cases about

58. See infra notes 119-25 and accompanying text.

59. See Unocal Corp. v. Mesa Petroleum Co., 493 A.2d 946, 956 n.13 (Del. 1985) (describing greenmail as "the practice of buying out a takeover bidder's stock at a premium that is not available to other shareholders in order to prevent the takeover").

60. See, e.g., Alcott v. Hyman, 208 A.2d 501, 508 (Del. 1965).

61. Greenmail, of course, has practically disappeared now that it is taxed at $50 \%$ in the United States. See I.R.C. $\$ 5881$ (West 2000).

62. Leading cases preventing uneven division of corporate wealth are Nixon v. Blackwell, 626 A.2d 1366 (Del. 1993) (en banc), and Donahue v. Rodd Electrotype Co. of New England, 328 
"watered stock" ${ }^{\text {"63 }}$ typifies this principle of even division. It is motivated by the notion that each shareholder should receive a claim truly proportional to each shareholder's contribution. ${ }^{64}$

Nevertheless, the threat to control was not sufficiently unverifiable and evanescent to take the Delaware courts back to the mode of discourse used in the watered stock cases. In the classic greenmail case, Cheff $v$. Mathes, ${ }^{65}$ instead of a threat to the proper distribution of corporate assets, the court was more concerned with the role of the board of directors. ${ }^{65}$ Should this greenmail transaction that led to the standstill agreement receive the benefit and near-immunity that the business judgment rule provides, according to which the courts do not secondguess the directors' business decisions? ${ }^{67}$ Indeed, if we are thinking along the lines of dilution of shareholder value, the members of the board as shareholders would be hurt by the disproportionate greenmail distribution to the hostile suitor and self-interest does not appear as the likely motive for the transaction. Nevertheless, the courts did suspect that it would be possible for the board to be engaging in some subtle form of self-dealing. ${ }^{65}$

How could the board be self-dealing while losing money as shareholders? They are because they are receiving something worth more than their loss. What the board receives in the greenmail situation is entrenchment in their position as controllers of the corporation. Accordingly, the Delaware Supreme Court stated in Cheff that only greenmail payments that are supported by valid business purposes will be upheld:

The question then presented is whether or not [the directors] satisfied the burden of proof of showing reasonable grounds to believe a danger to corporate policy and effectiveness existed by the presence of the [hostile] stock ownership. It is important to remember that the directors

N.E.2d 505 (Mass. 1975). An extensive discussion of shareholder oppression exists in Edward B. Rock \& Michael L. Wachter, Waiting for the Omelette to Set: Match-Specific Assets and Minority Oppression, in CONCENTRATED CORPORATE OWNERSHIP, supra note 21, at 201, 201-40.

63. See, e.g., Haselbush v. Alsco of Colo., Inc., 421 P.2d 113, 114 (Colo. 1966) (en banc).

64. See, e.g., Bing Crosby Minute Maid Corp. v. Eaton, 297 P.2d 5, 7 (Cal. 1956) (en banc); see also DEL. CODE ANN. tit. 8, § 162 (1991 \& Supp. 2000) (holding shareholders liable for watered stock issuance). But see DEL. CODE ANN. tit. 8, $\$ 152$ (1991) (making the determination of the board of directors regarding the value of the shareholders' contribution only assailable for "actual fraud").

65. 199 A.2d 548 (Del. 1964).

66. See id. at 556 .

67. See, e.g., BLACK's LAW DictionaRY, supra note 5, at 200.

68. See Cheff, 199 A.2d at 554. 
satisfy their burden by showing good faith and reasonable investigation ....69

The Delaware Supreme Court would not uphold greenmail payments if primarily motivated by a desire for entrenchment in control. $^{70}$

This treatment of greenmail by the Delaware courts was a defining moment in the evolution of corporate law. Had Delaware insisted on equal treatment of shareholders, practically none of the modern defensive tactics (both recapitalizations and securities) would be conceivable. Typical is the treatment by the Delaware courts of the paradigmatic defense of a coercive self-tender and the exemplary defensive security known as the poison pill." Both defenses operate by discrimination, by treating friendly and hostile shareholders differently. ${ }^{72}$

\section{b. The Coercive Self-Tender}

The coercive self-tender consists of a buy-back offer by the target corporation to its own shareholders. ${ }^{73}$ The hostile suitor is excluded from the offer. The corporation repurchases (or simply threatens to repurchase) its own shares at a premium. As a result, the surviving shares are worth less: the corporation "lost" the premium. Shareholders do not mind this reduction in value because they are the recipients of this premium. The hostile suitor bears the loss and is left holding the proverbial "bag."

\section{c. The Poison Pill}

The "poison pill" is a security which operates very similarly. It entitles its holders to contingent rights which would have similar dilutive effects to the distribution of a premium. ${ }^{75}$ The contingency is a hostile

69. Id. at 555 .

70. See id. at 554 .

71. See, e.g., Grand Metro. Pub. Ltd. v. Pillsbury Co., 558 A.2d 1049, 1056-60 (Del. Ch. 1988) (stating that poison pills may be valid in Delaware if they meet several factors, including the reasonableness of the poison pill defense in relation to the threat posed).

72. See Michael B. Regan, Note, Dead End: Delaware's Response to the Recent Innovation in Corporate Antitakeover Measures, the So-Called "Dead Hand" Poison Pill, in Carmody v. Toll Brothers, Inc., 44 VILL. L. REV. 643, 643 \& nn.2-3 (1999).

73. See Shamrock Holdings, Inc. v. Polaroid Corp., 559 A.2d 278, 287 (Del. Ch. 1989).

74. I will discuss a coercive self-tender in greater detail below. See infra notes 93-107 and accompanying text (discussing the Unocal case).

75. See, e.g., 3 JAMES D. COX ET AL., CORPORATIONS $\S 23.7$ (Supp. 2000). 
acquisition of a given percentage of shares in the target. ${ }^{76}$ Holders usually receive the right to buy additional shares at a discount. ${ }^{77}$ The hostile suitor, whose stake shrinks in value as well as in percentage ownership of the target, does not have this right. Despite the unequal division of shareholders value, the poison pill was considered an appropriate defense by the Delaware Supreme Court. ${ }^{78}$

The ability to discriminate between shareholders is instrumental for the defensive tactics that are used most often by American corporations. Very different defenses would have to be used if corporate law mandated the equal treatment of friendly and hostile shareholders. Without the ability to discriminate among shareholders, defensive measures would need to include outside entities. These would be third parties who would enter into contractual relations that would have contingencies producing deterrent effects on hostile buyers. Such contracts exist; they do not have to be imagined. Not only have target corporations often used outside entities to protect control, but also in the context of a merger of similarly sized corporations, each merging corporation acts to protect the control of the other against the possibility that a third party tries to buy one of the two. ${ }^{79}$

Some outside entities provide such protection, and are thus known as "white knights." "Typically management agrees to sell the corporation to the white knight. The hostile suitor may still buy control with a tender offer. To prevent the hostile suitor from outbidding the white knight, the target enters into contracts that give value of the target to the white knight (known as "lockups"). ${ }^{81}$ A characteristic example is the value that Revlon gave to Forstmann Little in order to fend off Perelman's hostile acquisition. ${ }^{82}$ Forstmann received the right to buy a unit of Revlon for a discount of $\$ 100$ to $\$ 175$ million from its estimated value, plus a $\$ 25$ million "cancellation fee" that would be due to

76. See id.

77. See id.

78. See Moran v. Household Int'l, Inc., 500 A.2d 1346, 1357 (Del. 1985) (indicating that the propriety of the poison pill's use is to be determined on a case-by-case basis).

79. See, e.g., Paramount Communications, Inc. v. Time, Inc., Nos. 10866, 10670, 10935, 1989 Del. Ch. LEXIS 77, at *28 (Del. Ch. July 17, 1989), aff'd, 571 A.2d 1140 (Del. 1989).

80. See BLACK'S LAW DICTIONARY, supra note 5, at 1591 (defining a "white knight" as "a person or corporation that rescues the target of an unfriendly corporate takeover, [especially] by acquiring a controlling interest in the target corporation or by making a competing tender offer").

81. See id. at 951 (defining "lockups" and "lockup options").

82. See Revlon, Inc. v. MacAndrews \& Forbes Holdings, Inc., 506 A.2d 173, 178 (Del. 1986). For a discussion of Revlon, see infra notes 109-14 and accompanying text. 
Forstmann Little if it lost the takeover battle. ${ }^{83}$ This reduced the value of Revlon to the competing bidder by $\$ 125$ to $\$ 200$ million. $^{84}$

Similar lockups are used in mergers. Each corporation grants the other side rights to stock, property, intellectual property, or other rights and entitlements. The effect is to reduce the value of the two merging corporations to potential hostile bidders. A typical example is the share exchange used by Time and Warner before their merger, by which they contracted to exchange blocks of stock of about $10 \%$ in each other. ${ }^{85}$ One of the effects of the share exchange agreement is the transfer of value to the other side if one party becomes subject to a hostile bid. ${ }^{86}$ If, for example, a bidder for Time were to increase dramatically the value of Time shares but not of Warner shares, the share exchange would benefit Warner. The share exchange also makes the acquisition of the control of one of the merging entities harder, because the issuance of the shares will dilute the acquirer's stake. Viacom's subsequently enjoined bid for Paramount provides one more example of a lockup. ${ }^{87}$ The merger agreement contained a termination fee of $\$ 100$ million that would be due to Viacom if the merger fell through. ${ }^{88}$ Viacom also received the right to buy almost $20 \%$ of Paramount's shares for $\$ 69.14$, close to the initially agreed upon consideration for the buyout. ${ }^{89}$ Viacom could elect to pay with subordinated debt for this stock or to demand an equivalent cash payment instead of exercising its option. ${ }^{90}$ The effect was that a hostile acquirer for Paramount would consider Paramount less appealing to the tune of $\$ 100$ million plus one-fifth of the difference between the hostile bid and Viacom's initial bid. ${ }^{91}$

83. See Revlon, 506 A.2d at 178 .

84. Resulting from the addition of the $\$ 25$ million cancellation fee to the $\$ 100-\$ 175$ million discount.

85. See Paramount Communications, Inc. v. Time, Inc., Nos. 10866, 10670, 10935, 1989 Del. Ch. LEXIS 77, at $* 28$ (Del. Ch. July 17, 1989), aff'd, 571 A.2d 1140 (Del. 1989). For a more extensive discussion of Time, see infra notes $115,117-21$ and accompanying text.

86. See id. at $* 28$.

87. See Paramount Communications, Inc. v. QVC Network, Inc., 637 A.2d 34, 39 (Del. 1993). For a more extensive discussion of $Q V C$, see infra notes $116,122-25$ and accompanying text.

88. See id. at 39.

89. See id.

90. See id.

91. The cost to the hostile acquirer of one-fifth of the amount by which its bid exceeds Viacom's initial bid corresponds to the effect of the options and becomes clearer if we consider that Viacom would simply demand a cash payment so that no additional shares would have to be issued. Suppose Paramount had 100 million shares outstanding. Viacom's option was for the appreciation corresponding to $20 \%$ or one-fifth. Someone who bids $\$ 10$ higher than Viacom's initial bid would cause the price of Paramount shares to rise by $\$ 10$ above Viacom's bid. Then Viacom would demand a payment corresponding to its option to buy $20 \%$, or 20 million shares in this example, for 
Once Delaware had taken the step of allowing discrimination among shareholders for the purpose of protecting corporate policy, the arena within which the law of corporate defenses would evolve had been chosen. This choice largely predicted the outcome: defensive tactics founded on discriminating between shareholders would be much more likely to be undertaken than defensive tactics which rely on an outside entity. Not only do discriminatory defensive tactics prevent the diversion of corporate value to outsiders but outsiders also pose a threat to the very control they have protected. Outsiders cannot be relied upon to tolerate ineffective management for long. If the European trend of prohibiting discrimination among shareholders continues, ${ }^{92}$ it will produce a takeover regime very different from that of the United States.

$\$ 10$ below the acquisition price. Paramount would owe $\$ 10$ for each share to which Viacom had an option, which is one of every five shares. This debt is equal to one-fifth of the total increase in value due to the competing bid, i.e., 20\% of the increased capitalization of Paramount beyond the capitalization implied by Viacom's first bid. In other words, the acquired Paramount would owe Viacom one-fifth of the extra value that the buyer considered Paramount to have above Viacom's bid.

The calculation is slightly different in the case that Viacom is assumed to have the stock issued so that Viacom would purchase it at the price specified by the option. Suppose that Paramount had 100 million shares outstanding and the competing bidder, as above, offers $\$ 10$ per share more than Viacom, or $\$ 79.14$. To fulfill Viacom's option, Paramount would issue 20 million shares at $\$ 69.14$. Thus, Viacom would get slightly less than $20 \%$ (actually $20 \div 120=16.67 \%$ ) in the enterprise that the competing buyer considered worth $\$ 79.14 * 100$ million $=\$ 7914$ million. Paramount would also become slightly more valuable by virtue of Viacom's payment for the shares. That payment would be $\$ 69.14 * 20$ million $=\$ 1382.8$ million. The net effect is that Viacom would obtain $16.67 \%$ of an enterprise worth $\$ 9296.8(7914+1382.8)$ million, of existing value plus value injected by Viacom's purchase. Viacom's share would correspond to about $\$ 1549.78$ million, and would have been purchased for $\$ 1382.8$ million. This would be a windfall of about $\$ 167$ million. This corresponds to Viacom's $16.67 \%$ share in the increased valuation. The formula for the calculation of Viacom's windfall would be (bid * out $+.2 *$ out $* \$ 69.14) *(.2 \div 1.2)-(.2 *$ out $*$ $\$ 69.14$ ) which simplifies to $.2 *$ out $*$ (bid -69.14$) \div 1.2$, where (out) is the number of outstanding shares and (bid) is the per share value of the winning bid. Note that Viacom prefers the previous outcome where it receives the full $20 \%$ of the increased valuation, while if it exercises its option it only receives $16.67 \%$. The competing bidder adjusts its bid the same way regardless of which choice Viacom would make. The competing bidder with a valuation (v) will take Viacom's option to buy a fraction (op) of the shares for a "strike price" (str) into account and will bid $(v+o p * s t r) \div$ $(1+o p)$ per share rather than his full valuation $V$ because it values the enterprise after Viacom's exercise at $(v * o u t+o p * o u t * s t r)$ and this value would be divided among $(1+o p)$ out shares. If Viacom were to elect to take cash, the bid would have to be equal to the valuation minus Viacom's extraction of value which is op(bid - str). The solution to bid $=v-o p(b i d-s t r)$ for (bid) is identical to the previous calculation of the competing bidder's bid (which assumed Viacom would exercise its option).

92. See infra Part III.C. 
2. Fine-Tuning Discriminatory Defenses

Although the principle of allowing strong defensive moves had already been established by allowing discriminatory defenses, not every defense would survive scrutiny. The rule would be fine-tuned as management would try increasingly strong defenses. Defenses would need not to exceed an intensity proportional to the threat posed by the hostile acquirer. An end-point would also be imposed to the contest, after which defenses would need to be withdrawn.

\section{a. The Proportionality of Defenses: Unocal}

In Unocal Corp. v. Mesa Petroleum Co., ${ }^{93}$ Unocal, a petroleum company, became the target of a hostile takeover bid by Mesa Petroleum. ${ }^{94} \mathrm{~T}$. Boone Pickens, whose notoriety as a takeover artist is partially due to this very fight, had working control of Mesa. ${ }^{95}$ Mesa had acquired $13 \%$ of Unocal by the time it announced a bid for the $37 \%$ that would give Mesa majority control of Unocal. ${ }^{96}$ In the associated disclosures, Mesa announced that it would complete a merger with Unocal. ${ }^{97}$ The consideration that the remaining minority shareholders of Unocal would receive in the merger included debt securities. ${ }^{98}$

Unocal's defense was to threaten a discriminating transaction that would reduce the value of Mesa's position. ${ }^{99}$ Unocal would make a tender offer for its own stock at a price well above market to which Mesa would not be allowed to tender its shares. ${ }^{100}$ This overpriced buyback from public shareholders would dramatically reduce the value of surviving shares. While public shareholders would be compensated for the reduction in value by means of the premium they would receive for the shares they did sell, Mesa would suffer this drop in value unmitigated.

An example will clarify the effect of the transaction. Suppose Unocal has assets of $\$ 100$, equivalent capitalization of $\$ 100$ and 100

93. 493 A.2d 946 (Del. 1985).

94. See id. at 949 .

95. See id. Pickens's working control was not enough to prevent his own ouster when Mesa's performance became unsatisfactory. See Allen R. Myerson, Revamping is Approved for Mesa, N.Y. TIMES, June 26, 1996, at D4.

96. See Unocal, 493 A.2d at 949.

97. See id.

98. See id. at $949-50$.

99. See id. at $950-51$.

100. See id. 
shares outstanding. ${ }^{101}$ Mesa owns thirteen of those shares and makes its offer for thirty-seven more. Mesa's position is worth $\$ 13$. Unocal offers to buyback fifty shares, pro rata from each non-Mesa shareholder for $\$ 1.50$ by using corporate assets (in actuality it was mainly borrowing funds by pledging assets, which would have the same effect). ${ }^{102}$ Thus, Unocal's assets would be reduced by $50 * \$ 1.50=\$ 75$ to $\$ 25$ of remaining assets. The fifty shares that would survive as outstanding after the buyback would share in this value. They would be worth $\$ 25 \div 50=$ $\$ 0.50$ each. The effect on Mesa is that its thirteen shares drop in value from $\$ 13$ to $\$ 6.50$. The public shareholders, however, do not mind the transaction because they participate in the distribution through the buyback. Moreover, since Mesa is excluded from the buyback, public shareholders participate in the distribution of value through the buyback disproportionately, to the extent Mesa is excluded.

Not only is this transaction detrimental to Mesa, but it is also coercive to shareholders. Public shareholders who believe Mesa's offer superior to the position in which Unocal's counter would leave them, cannot afford to pass Unocal's self-tender. Thus, the fight for control is no longer an auction in which the superior offer will win, but a foregone conclusion in favor of Unocal.

Before turning to the Delaware courts' treatment of this transaction, it is worth thinking about its effect on the concentration of ownership. Mesa was controlled by Pickens. ${ }^{103}$ The ownership of Unocal was dispersed..$^{104}$ Thus, if Mesa were to take over Unocal in exchange for cash and debt, the combined entity would be under the working control of Pickens.

The ostensible reason that the court allowed the Unocal counter was that Mesa's offer was a threat because it had two tiers. The first tier, the cash that Mesa offered in the tender offer for the shares it needed to reach $50 \%$, did not match the consideration in the second tier which included securities. ${ }^{105}$ Unocal argued that Mesa's offer was coercive. ${ }^{106}$

101. Capitalization is the value of all the outstanding shares of the corporation. See BLACK'S LAW DICTIONARY, supra note 5, at 202. Here, each share is worth $\$ 1$ and 100 shares exist, making the capitalization $\$ 100$.

102. The buyback is prorated according to SEC Rule $14 d-8$, which requires a tender offeror to repurchase proportionate amounts from all shareholders in cases of oversubscribed tender offers. See 17 C.F.R. $\$ 240.14 d-8$ (2001). Unocal's offer would be oversubscribed because all shareholders would tender in order not to lose the premium.

103. See supra note 96 and accompanying text.

104. See Unocal, 493 A.2d at 949.

105. See id. at 956.

106. See id. at 953 . 
Shareholders could not afford to get stuck with the less liquid and the, in Unocal's view, less valuable securities, and they would, therefore, accept Mesa's inadequate offer despite preferring the alternative, which was keeping their Unocal shares.

Under this reasoning, Unocal's much more coercive defensive offer was a proportional response to the threat. Management are not entitled to coerce their own shareholders, but in these circumstances, the coercive offer was allowed. The true source of the court's decision could well be that the transaction would lead to a concentration of ownership. ${ }^{107}$

\section{b. The You-Lost-You-Must-Sell Endpoint: Revlon}

The alternative to a discriminatory defense is a friendly merger. For target management, the problem lies in ensuring that the friendly buyer outbids the hostile one. To secure a high bid, the target needs to grant valuable lockups to the friendly bidder. ${ }^{108}$ The Delaware courts reviewed the use of this tactic in Revlon, Inc. v. MacAndrews \& Forbes Holdings, Inc. ${ }^{109}$

The hostile acquirer, Ronald Perelman's corporation Pantry Pride, kept increasing its bids for Revlon. ${ }^{110}$ Revlon sought protection from a private leveraged buyout partnership, Forstmann, Little, \& Co. ${ }^{\text {II }}$ In order for Forstmann Little to keep outbidding Pantry Pride, greater and greater lockups were required. At some point, according to the court, it became clear that Revlon would have to be broken up. ${ }^{12}$ The increasing bids and ever greater lockups implied that the buyer would have to sell parts of the target.

Since the target corporation would not survive the transaction, target management was not entitled to protect corporate policy by biasing the process in favor of the bidder it preferred. ${ }^{113}$ When the

107. The SEC has used its authority to regulate tender offers so as to ban discriminatory tender offers, precluding a repetition of the Unocal defense. See 17 C.F.R. $\$ 240.13 \mathrm{e}-4$ (f)(8)(i) (2001); id. $\$ 240.14 \mathrm{~d}-10$ (a)(1) (2001) ("No bidder shall make a tender offer unless ... [t] the tender offer is open to all security holders of the class of securities subject to the tender offer ...."). I discuss the desirability of this prohibition below, see infra note 424 and accompanying text.

108. See David A. Skeel, Jr., A Reliance Damages Approach to Corporate Lockups, 90 Nw. U. L. REV. 564, 600 (1996).

109. See Revlon, Inc. v. MacAndrews \& Forbes Holdings, Inc., 506 A.2d 173, 176 (Del. 1986).

110. See id. at $178-79,181$.

111. See id. at $177-78$.

112. See id. at 182 .

113. See id. 
breakup of the target became clear, its management was obligated to step back and let the auction go on without bias. ${ }^{1 / 4}$

3. Concentration Matters: From Revlon, to Time and $Q V C$

The holding in Revlon had very much to do with preventing concentrated ownership, but that becomes more apparent if Revlon is juxtaposed with two seemingly contradictory decisions, Paramount Communications, Inc. v. Time, Inc. ${ }^{115}$ and Paramount Communications, Inc. v. QVC Network, Inc. ${ }^{116}$

In Time, Warner and Time had decided to merge. ${ }^{17}$ Paramount decided to make a hostile bid for Time and let the shareholders decide between the lackluster merger and its lucrative cash offer. ${ }^{118}$ The bid was conditioned on removal of lockups and other measures safeguarding the pending Time-Warner merger. ${ }^{119}$ Perhaps Paramount was hoping for a broad interpretation of Revlon: that management of the target must not bias the auction if a sale of the corporation is unavoidable.

The Delaware Supreme Court foiled Paramount's hopes and stated that the merger of Time with Warner constituted a strategic alliance. ${ }^{120}$ The strategic alliance was a long-term plan that would survive the transaction. The shareholders of Time would participate in its success or failure. Therefore, the strategic alliance was a sufficient corporate interest for target management to protect with the lockups and the other transaction-protecting terms of the Time-Warner agreement. ${ }^{121}$

Soon after, the Delaware Supreme Court would distinguish Time from a very similar transaction. Having learned its lesson from Time, Paramount set up a strategic alliance with Viacom and erected the usual lockups and other defenses to guard it. ${ }^{122} \mathrm{QVC}$, however, made a bid for Paramount contingent on the removal of the deal's defenses. ${ }^{123}$

114. See id. (describing the director's role as changing from defenders of the "corporate bastion" to "auctioneers" with a duty to get the best price possible for the stockholders from the sale of the company).

115. 571 A.2d 1140 (Del. 1989). The effects of the Time decision on conglomeration incentives and market liquidity are briefly discussed below, see infra note 399 .

116. 637 A.2d 34 (Del. 1993).

117. See Time, 571 A.2d at 1147 .

118. See id.

119. See id.

120. See id. at 1149-51.

121. See id. at 1151.

122. See Paramount Communications, Inc. v. QVC Network, Inc., 637 A.2d 34, 39 (Del. 1993).

123. See id. at 40 . 
In an abrupt turnaround, the Delaware Supreme Court held in $Q V C$ that the merger with Viacom was unlike the merger of Time with Warner. ${ }^{124}$ The difference lay in that Viacom was over $70 \%$ controlled by a single individual, Sumner Redstone, and the resulting entity would be under his majority voting control. ${ }^{125}$ Since the shareholders of Paramount would never again have the opportunity to receive a premium for control, its sale should be conducted by auction. By contrast, the shareholders of Time could still receive a premium for control because someone could bid to take over the combined Time-Warner entity.

In its prior cases-Cheff v. Mathes ${ }^{126}$ and Moran v. Household International, Inc., ${ }^{127}$ as well as in Unocal, Revlon, and Time-the protection of dispersed ownership was never overt. However, in the $Q V C$ opinion, the Delaware Supreme Court finally expressed its desire to avoid concentrated ownership. In $Q V C$, the court stated that a sale by merger that would result in an individual owning majority voting control could not be protected..$^{128}$ By contrast, in Time, the Delaware court held that a sale by merger which preserved dispersed ownership could be protected by lockups and other defensive measures. ${ }^{129}$

Revlon, the case which first imposed a duty to auction, does not seem to fit in that continuum. Either buyer would lead to concentrated ownership. A purchase by Pantry Pride would lead to control by Ronald Perelman and a purchase by Forstmann Little would lead to control being exercised by the Forstmann Little firm which is organized as a professional partnership.

The Revlon puzzle unravels if we consider it as the test of white knight defenses. Leveraged buyout firms ("LBO firms") are typically organized as partnerships, just like Forstmann Little. ${ }^{130}$ Target management, pressed to find a white knight, would tend to turn to these vehicles of concentrated ownership. Revlon stopped such a trend toward concentrated ownership from forming. LBO firms would not become an

124. See id. at 43 .

125. See id. at 38,43 .

126. 199 A.2d 548 (Del. 1964); see also supra notes 65-66 and accompanying text.

127. 500 A.2d 1346 (Del. 1985). Moran upheld the use of the poison pill. See supra note 78 and accompanying text.

128. See Paramount Communications, Inc. v. QVC Network, Inc., 637 A.2d 34, 43 (Del. 1993).

129. See Paramount Communications, Inc. v. Time, Inc., 571 A.2d 1140, 1151 (Del. 1989).

130. See Jason M. Klein, When the Board Should Just Say Yes to Management: The Interplay Between the Decision of Whether to Conduct an Auction and Transaction Structure, 5 STAN. J.L. Bus. \& FIN. 45, 46 (1999). 
effective defensive tool. Thus, the Delaware courts preempted such a trend toward concentrated ownership.

4. Delaware's Bias Against Uncontested Unilateral Privatization

All the discretion that the Delaware courts appear to give managers in the context of defenses disappears before a different threat to dispersed ownership. If managers attempt to take their own company private, the Delaware courts will be as exacting as they were permissive in defensive tactics.

The definitive Delaware case on privatizing transactions is Weinberger v. UOP, Inc. ${ }^{131}$ where shareholders of UOP, Inc. challenged the buyout of their minority shares by Signal, the parent and majority owner of the corporation. ${ }^{132}$ The standard that the Delaware Supreme Court articulated demands not only that the substantive terms of the buyout transaction be fair, but also that the procedure used to achieve it be fair. ${ }^{133}$ This substantive and procedural fairness is illustrated nicely in the shortcomings of the privatization of UOP. ${ }^{134}$

The first stumbling block for the court was the use by the parent of the subsidiary's information collected by directors of the subsidiary that were employees of the parent. ${ }^{135}$ Not only was the parent given this information, but there was no disclosure to the subsidiary that its own directors played this role that was adverse to the subsidiary's interests. ${ }^{136}$ Quite contrary from an attempt at "puffery" initiated for the benefit of the subsidiary, this information was kept from it because it could be used to justify a higher price than was ultimately accepted. ${ }^{137}$ Indeed, the court notes:

Since the study was prepared by two UOP directors, using UOP information for the exclusive benefit of Signal, and nothing whatever was done to disclose it to the outside UOP directors or the minority shareholders, a question of breach of fiduciary duty arises. This problem occurs because there were common Signal-UOP directors participating, at least to some extent, in the UOP board's

131. 457 A.2d 701 (Del. 1983).

132. See id. at 703.

133. See id. at 711 .

134. See id. at 711-14.

135. See id. at 709 .

136. See id.

137. See id. 
decision-making processes without full disclosure of the conflicts they faced. ${ }^{138}$

The court proceeds to examine the decision-making process that led the subsidiary to accept the parent's offer. What surfaces is that the parent not only tried to profit from the subsidiary's information at the subsidiary's expense, but it also set a harried pace for the subsidiary's reaction, and indirectly forced an excessively speedy valuation by the subsidiary's investment banker. ${ }^{139}$

Thus, the Weinberger court banishes any cavalier attitude that a majority shareholder may have about its capacity to force a buyout of the minority's shares. Unless the subsidiary negotiates in a truly independent fashion, the procedure is suspect. Even a favorable vote by the majority of the minority shareholders-as existed in Weinbergercannot cure this failure. Finally, even if this exacting procedure is followed, an unfair price will still be unacceptable.

The Weinberger test of fairness received a trial by fire in Kahn $v$. Lynch Communication Systems, Inc. ${ }^{140}$ which addressed the attempt of a large shareholder, Alcatel (with 43\%), to buy Lynch. ${ }^{141}$ The relationship between Lynch and Alcatel was not quite that of a subsidiary and parent. Nevertheless, Alcatel dominated Lynch because it held a crucial veto right. $^{142}$ By virtue of a supermajority provision, Lynch could not effectuate any corporate combination without Alcatel's support. ${ }^{143}$ This right was crucial because the telecommunications industry was at such a juncture that Lynch needed to merge with another company in order to exploit the evolving technology. ${ }^{144}$ Alcatel had already blocked one attempt of Lynch to merge with another telecommunications company, and had counterproposed a merger with a subsidiary of Alcatel. ${ }^{145}$ That deal did not materialize when Lynch's independent negotiating committee refused Alcatel's offers. ${ }^{146}$ In response, Alcatel offered to purchase Lynch. ${ }^{147}$ When negotiations were about to fail because the

138. Id. at 709. In a footnote at the end of this excerpt, the Delaware Supreme Court explained that had UOP conducted negotiations with Signal through a committee of disinterested directors, this conflict of interests would probably be cured. See id. at 709 n.7.

139. See id. at 711 .

140. 638 A.2d 1110 (Del. 1994).

141. See id. at 1112.

142. See id.

143. See id.

144. See id.

145. See id.

146. See id. at 1113 .

147. See id. 
independent negotiating committee did not consider its ' bid' adequate, Alcatel made it clear that it would proceed with a lower hostile offer. ${ }^{148}$ Faced with this threat, the resolve of the independent negotiating committee broke.

When sued by the minority shareholders, Alcatel offered what appeared to be a Weinberger defense: The terms of the merger were approved by an independent committee of the board. ${ }^{149}$ The Delaware Supreme Court, however, explained that an independent committee that is strong-armed by the controlling shareholder will not insulate the controlling shareholder's inadequate bid: "[T] he special committee must have real bargaining power that it can exercise with the majority shareholder on an arms length basis." 150 Indeed, Alcatel had robbed Lynch of any alternative. Mergers with non-Alcatel companies were blocked by Alcatel; ${ }^{151}$ mergers with Alcatel-controlled entities were only available at disadvantageous terms; ${ }^{152}$ and independence for Lynch in the face of a hostile Alcatel offer required a poison pill that the independent committee considered impractical. ${ }^{153}$ This was a classic breach of fiduciary duties.

The question arises, however, how precisely does the exacting standard of minority protection of Weinberger and Kahn promote dispersed ownership? After all, the issues appear circumscribed to corporations that already have a majority owner, and are, therefore, not under dispersed ownership. The seamless web of corporate law does not cover this point. Courts have not spoken precisely about the standards that govern management's attempts to purchase not majority but only working control from the public. It is quite paradoxical that this crucial transition in a corporation's affairs is below the radar screens of the legal system. ${ }^{154}$ Even that question, insofar as it applies to hostile acquisitions,

148. See id. at 1119.

149. See id.

150. Id. at 1117 (quoting Rabkin v. Olin Corp., No. CIV.A.7547, 1990 WL 47648, at *14-15 (Del. Ch. Apr. 17, 1990), aff'd, 586 A.2d 1202 (Del. 1990)).

151. See id. at 1112 .

152. See id. at 1118 .

153. See id. at 1113 n. 3 (indicating that the independent committee considered the resulting debt unacceptable).

154. One may consider the question of whether an acquirer's purchases constitute a tender offer similar to the question of whether management's expanding (but still minority) stake crosses some threshold of scrutiny. As soon as the Williams Act's amendments to the securities laws imposed a delay and other regulatory constraints on tender offers, see Williams Act, Pub. L. No. 90-439, 82 Stat. 454 (1968) (codified as amended in scattered sections of 15 U.S.C.), hostile acquirers attempted to circumvent them by not making a general solicitation to shareholders to tender their shares and, instead, tried to make "creeping" acquisitions of control. The ensuing litigation left the question of what constitutes a tender offer as vague as it ever was, but the advent 
is outdated due to the proliferation of poison pills that prevent creeping acquisitions of control. ${ }^{155}$ Nevertheless, not only the argumentation of

of poison pills precluded the strategy and the issue never received the attention that it probably should have. See generally Dale A. Oesterle, The Rise and Fall of Street Sweep Takeovers, 1989 DUKE L.J. 202, 256 (explaining that although poison pills originated as a means of stopping hostile acquisitions, they have not been very successful in stopping hostile acquisitions but they have been significant in regulating the forms that the hostile acquisitions have taken). Typical cases are Wellman v. Dickinson, 475 F. Supp. 783, 805 (S.D.N.Y. 1979), affd, 682 F.2d 355 (2d Cir. 1982), where the court held that a $34 \%$ acquisition from twenty-two sellers out of twenty-eight solicited was a tender offer; and Hanson Trust PLC v. SCM Corp., 774 F.2d 47 (2d Cir. 1985). In Hanson Trust, the acquisition of $25 \%$ of the target in a single transaction from five sellers after termination of a tender offer was not considered to be a tender offer. See id. at 52, 60 .

155. The 1998 poison pill of American General Insurance Corporation, for example, is triggered either by an acquisition of $15 \%$ of the stock or by a tender offer resulting in holdings greater than $25 \%$ :

The Rights are not exercisable or transferable separately from the shares of Common Stock until the "Distribution Date" which will occur on the earlier of (i) 10 business days following the first public announcement that a person or group of affiliated or associated persons (an "Acquiring Person") has acquired beneficial ownership of 15\% or more of the outstanding Common Stock and any other shares of capital stock of the Company entitled to vote generally in the election of directors or entitled to vote in respect of any merger, consolidation, sale of all or substantially all of the Company's assets, liquidation, dissolution or winding up of the Company (the "Voting Stock") or (ii) 10 business days following the commencement of, or the first public announcement of an intention to commence, a tender or exchange offer the consummation of which would result in the beneficial ownership by a person or group of affiliated or associated persons of $25 \%$ or more of the then outstanding Voting Stock.

AMERICAN General CoRP., Registration Statement, Form S-3, at 63-64 (Feb. 9, 1998), available at http://www.sec.gov/Archives/edgar/data/5103/0000950129-97-004921.txt (last visited Oct. 16, 2001). The pill entitles friendly shareholders to 100 times the votes, dividends, or any other distributions to common stock by giving them "junior preferred shares":

The Junior Preferred Shares will be non-redeemable and rank junior to all other series of the Company's Preferred Stock. Each whole Junior Preferred Share will be entitled to receive a quarterly preferential dividend in an amount equal to the greater of (i) $\$ 0.25$ or (ii) subject to certain adjustments, 100 times the dividend declared on each share of Common Stock. In the event of the liquidation, dissolution or winding up of the Company, each whole Junior Preferred Share will be entitled to receive a preferential liquidation payment in an amount equal to the greater of (i) $\$ 1.50$, or (ii) 100 times the aggregate amount to be distributed per share to holders of Common Stock, plus, in either case, an amount equal to all accrued and unpaid dividends thereon. In the event of any merger, consolidation or other transaction in which Common Stock is exchanged for or changed into other stock or securities, cash or other property, each whole Junior Preferred Share will be entitled to receive 100 times the amount received per each share of Common Stock. Each whole Junior Preferred Share will be entitled to 100 votes on all matters submitted to a vote of the shareholders of the Company, and Junior Preferred Shares will generally vote together as one class with the Common Stock and any other voting capital stock of the Company on all matters submitted to a vote of shareholders of the Company.

Id. at 65 . 
this Article, but also voluminous economic evidence, ${ }^{156}$ points to the accumulation of a controlling minority block as a very significant event.

That the legal system is oblivious to "friendly creeping acquisitions" of working control is not hard to explain. A friendly creeping acquisition of working control requires a series of purchases. ${ }^{157}$ The particular purchase that produces working control is exceptionally hard to locate. Corporate management, holding a small fraction of shares, probably in the neighborhood of $0.1 \%$ to $5 \%$, decides to increase its stake to perhaps $25 \%$ or even $40 \%$. Excluding the overt tender offer that will trigger disclosure and attention, management can use any technique to increase its stake, including use of the corporate machinery it controls. Thus, the corporation itself can help management by means of buying back its own shares from its shareholders, resulting in an increase of management's percentage of outstanding shares. Moreover, management has the luxury to stretch its purchases over time. Unlike hostile creeping acquisitions, management does not have to fear the adoption of defensive tactics. Quite the opposite, management can erect roadblocks before any outsider's attempt to purchase control while adjusting its strategy and continuing to increase its holdings. The full impact of ostensibly defensive measures can be easily hidden in such a long-term strategy. A supermajority provision that requires $75 \%$ for all

156. Evidence shows that ownership concentration is important for overall firm value, and that not the same concentration is desirable for every firm. The most recent support is from Japanese evidence. See YORSHIRO MTWA \& J. MARK RAMSEYER, DOES OWNERSHIP MATTER? EVIDENCE FROM THE ZAIBATSU DISSOLUTION PROGRAM passim (John M. Olin Ctr. L. Econ. \& Bus., Working Paper Series, Discussion Paper No. 314, 2001) (indicating that after the break up by the U.S. occupation of the zaibatsu, restructured firms had suboptimal ownership structures and their value varied with ownership concentration; once concentration retumed to its optimal point, different for each firm, it no longer had an effect on valuation), available at http://www.law.harvard.edu/programs/olin_center (last visited Feb. 8, 2002); see also John C. Coffee, Jr., Liquidity Versus Control: The Institutional Investor as Corporate Monitor, 91 CoLUM. L. REv. 1277, 1294-1302 (1991); Harold Demsetz \& Kenneth Lehn, The Structure of Corporate Ownership: Causes and Consequences, 93 J. POL. ECON. 1155, 1159 (1985) (arguing that optimal ownership structure is firm-specific); John J. McConnell \& Henri Servaes, Additional Evidence on Equity Ownership and Corporate Value, 27 J. FIN. ECON. 595, 601 (1990) (indicating that firm value peaked at an inside ownership of 37.6\% in 1986); John J. McConnell \& Henri Servaes, Equity Ownership and the Two Faces of Debt, 39 J. FIN. ECON. 131, 156 (1995) (noting that the allocation of equity owmership stakes is more important in low-growth firms than in high-growth firms; high growth firms are more valuable if they have less debt, low growth firms are more valuable if they have more debt, supporting a discipline effect of debt on low growth, and a financing constraint effect on growth); Randall Morck et al., Management Ownership and Market Valuation: An Empirical Analysis, 20 J. FIN ECON. 293, 311-14 (1988) (studying the valuation of Fortune 500 corporations and finding that firm value increases, then decreases as the directors' ownership stake increases).

157. See, e.g., Glenn E. Coven, Taxing Corporate Acquisitions: A Proposal for Mandatory Uniform Rules, 44 TAX L. REv. 145, 180-81 (1989); Oesterle, supra note 154, at 208 n.43. 
corporate combinations looks innocuous when management has only $10 \%$. The same provision becomes an absolute bar to a hostile corporate combination when management's stake later exceeds $20 \% .{ }^{158}$

In the series of purchases that produce working control, identifying the one that solidifies working control is also futile. Indeed, the use of the word "solidifies" next to "working control" is paradoxical. Working control is never absolutely solid. Even with the privilege of the contemporary well-stoked defensive arsenal, the controlling group is vulnerable. Defenses may make working control less vulnerable to a hostile tender offer, but working control can still be defeated in a proxy fight. Thus, it is not hard to understand why the courts, even if they had been given the opportunity to examine creeping acquisitions of working control, would likely avoid drawing any lines. A rule hinging on a nefarious and mercurial concept such as working control is exactly the kind of quicksand that courts would avoid. We are much more likely to see the courts becoming involved in an ex post examination of the controlling group's actions using the well-developed methodology of fiduciary obligations.

Working control is an intermediate threat to minority shareholders. Working control is a greater threat than management with a truly small stake, but a smaller threat than a majority controller. Thus, the Delaware courts would (and should) require a higher standard in conflicted transactions regarding working control than from a management team with a truly small stake. ${ }^{159}$ We can visualize the courts' stance by considering the treatment of the same action, the adoption of a $75 \%$ supermajority provision for corporate combinations, as management's stake increases. When management has $3 \%$, a $75 \%$ supermajority provision for corporate combinations will in all likelihood be subject to the permissive business judgment rule. The same supermajority amendment becomes more likely to be considered an entrenching transaction as management's stake increases. When management has over $25 \%$ of the voting power, the same supermajority provision is clearly subject to scrutiny. It may entrench management and create a conflict of the interests of management with those of the shareholders that it represents. ${ }^{160}$ Similarly, the business judgment rule that inoculates

158. A similar issue did arise in a defensive repurchase proposed by Unitrin, see infra notes 160, 418-22 and accompanying text.

159. See Unitrin, Inc. v. Am. Gen. Corp., 651 A.2d 1361, 1373 (Del. 1995).

160. See, e.g., Am. Gen. Corp. v. Unitrin, Inc., No. CIV.A.13699, 13656, 13663, 13665, 13676, 13685, 13684, 1994 WL 512537, at *3 (Del. Ch. Aug. 26, 1994). Corporate buyback from the public would increase management's stake from $23 \%$ to $28 \%$, enough to veto corporate 
directors' actions against shareholder attack, ${ }^{161}$ would apply in fewer circumstances as a management team increases its stake. Ultimately, the transaction by which actual majority control is acquired will be subjected to the strict scrutiny akin to Weinberger. ${ }^{162}$

\section{The Dispersion-Preserving Choices of Delaware Law}

The development of the Delaware law on takeover defenses has been very gradual. Not every decision comes out in favor of dispersed ownership. ${ }^{163}$ Nevertheless, every major step that the Delaware courts have taken in their gradual shaping of defensive tactics can be seen as if designed to preserve dispersed ownership against trends favoring acquisitions from concentrated owners.

The courts' first choice was to allow greenmail. Some have criticized greenmail because of its inherent destabilizing effect: the acquirer is turned away but made richer; the target preserves independence but to its shareholders' financial detriment. ${ }^{164}$ The Cheff $v$. Mathes ${ }^{165}$ case should not be read as being about greenmail but about defensive tactics that discriminate between shareholders. The notion that

combinations given the target's $75 \%$ supermajority provision. See In re Unitrin, Inc., S'holders Litig., Nos. CIV.A.13656, 13699, 1994 WL 698463, at*3 (Del. Ch. Oct. 14, 1994), rev'd, 651 A.2d 1361 (Del. 1995). It was challenged by shareholders and by the hostile bidder it was intended to thwart. See id. at *4. The buyback was temporarily enjoined by the Court of Chancery with an analysis consistent with that above. See id. at *13-14. The Delaware Supreme Court, however, reversed the decision of the chancery court because the buyback program was not "preclusive" nor "draconian." See Unitrin, 651 A.2d at 1367. In other words, although it precluded a merger, it was not draconian because it did not preclude victory in a proxy fight; and because the actual voting power of the board, due to low turnout at shareholder meetings, already exceeded the $25 \%$ veto block. See id. at 1387-89. Note that if the board's holdings could already veto mergers, then the buyback has no sinister purpose. See id.

The Delaware Supreme Court's reversal of the lower courts, however, remains somewhat problematic because American General is dispersedly owned; the board of directors in aggregate owns about $1.5 \%$ and the largest shareholder only owns about $6 \%$ of the outstanding shares. See AMERICAN GENERAL 2000 PROXY STATEMENT 10-11 (Mar. 21, 2000), available at http://www.investquest.com/iq/a/agc/fin/proxy/agcx00.txt (last visited Aug. 22, 2000).

161. See Unitrin, 651 A.2d at 1373.

162. See supra notes $131-56$ and accompanying text.

163. See, e.g., infra notes $175-83$ and accompanying text (discussing Canada S. Oils, Ltd. v. Manabi Exploration Co., Inc., 96 A.2d 810 (Del. Ch. 1953)).

164. See generally Jonathan R. Macey \& Fred S. McChesney, A Theoretical Analysis of Corporate Greenmail, 95 YALE L.J. 13 (1985) (discussing greenmail extensively). Macey and McChesney also analyze four statistical studies of greenmail and argue that the greenmail payment in some cases causes gains to shareholders and in some cases, albeit the majority, it is detrimental. See id. at 43-48. More recent evidence on golden parachutes is discussed supra notes 4-7 and accompanying text.

165. 199 A.2d 548 (Del. 1964). 
an acquisition poses a threat to corporate policy was crucial. ${ }^{166}$ This led to the next step, that the board of directors is entitled to defend corporate policy. ${ }^{167}$

The protection of corporate policy justifies discrimination between shareholders. This humble birth of discriminatory defensive tactics was a crucial first step because without discriminatory defenses, the only avenue that target management could pursue to preserve control in the face of a hostile threat would be to enlist the assistance of a friendly acquirer, one of the white knights. Discriminatory defenses allowed target self-help, because they allowed the target corporations to protect their control with no outside assistance. Without this crucial choice, targets would be effectively forced into the arms of LBO funds and into concentrated ownership.

Not only were sales to concentrated LBO funds prevented from becoming the only available defense, but with Revlon they were rendered a defense that was unlikely to succeed. Thus, after preventing concentrated ownership from becoming the only foolproof defensive tactic, the Delaware courts also biased the choice of defenses by making the defensive merger less appealing.

Once concentration as a matter of course is prevented, the next issue becomes the preservation of ownership in the face of two competing acquirers. The Time and QVC pair suggest that target management will be allowed to defend mergers that preserve dispersed ownership and will not be allowed to defend mergers that concentrate ownership.

All this protection of dispersed ownership would be pointless, however, if friendly buyers, like management, were able to get to concentrated ownership unchecked. Again, the Delaware courts block this path to concentrated ownership by giving strong protection to the minority-protection that combined with the uncertainty of the law makes managerial acquisitions of control a delicate and costly endeavor. ${ }^{168}$

Managers, however, cannot be left to run the corporation with no checks. The only way to remove management without concentrating ownership is through proxy fights. ${ }^{169}$ Indeed, Delaware takes a very different stance on managerial interference with proxy fights than it does

166. See id. at 556.

167. See Unocal Corp. v. Mesa Petroleum Co., 493 A.2d 946, 955 (Del. 1985).

168. See infra Part MII.B.3.

169. See, e.g., Schnell v. Chris-Craft Indus., Inc., 285 A.2d 437, 439 (Del. 1971). 
on hostile takeovers. ${ }^{170}$ Again, however, management is given much more latitude if the proxy fight is part of a strategy that will lead to concentrated ownership. ${ }^{171}$

\section{B. Delaware's Neutrality to Dispersion-Preserving Changes of Control: Easy Proxy Fights}

In contrast to acquisitions, proxy fights alone do not change concentration. The insurgents start out as a minority and remain one, regardless of the proxy fight's outcome. More recently, proxy fights have been coupled with tender offers. ${ }^{172}$ This would make them part of a transaction that may concentrate ownership. Predictably, the courts would treat defenses to such proxy fights very differently.

The early disputes that arose in the context of proxy fights in Delaware produced dicta that denounced any interference that would tend to bias shareholder voting. ${ }^{173}$ More recently, however, the Delaware Court of Chancery placed the review of defenses to proxy fights in the scheme of the enhanced business judgment rule of Unocal. ${ }^{174}$ Nevertheless, what triggers the switch from no-interference to allowing defenses is a threat to dispersed ownership in the form of a tender offer that will follow the proxy fight.

\section{The Early Cases: Dicta Strictly Prohibiting Interference}

The early cases span the years when the cash tender offer was not yet widely used as a method for hostile acquisitions. Their language protects an absolute entitlement of the shareholders to vote without any interference by the board of directors.

The early example of Canada Southern Oils, Ltd. v. Manabi Exploration Co. ${ }^{175}$ reveals the attitudes of the Delaware judiciary. Canada Southern, controlled by the Buckleys, held 50.4\% of Manabi's shares. ${ }^{176}$ The Buckleys, and Hagan, the president of both Canada Southern and Manabi, ${ }^{\mathrm{m}}$ had a mild disagreement about the management of Manabi. ${ }^{178}$ Soon thereafter, a resolution authorizing the board to issue

170. See infra notes $189-215$ and accompanying text.

171. See infra Part III.B.3.

172. See infra Part III.B.3.

173. See infra Part III.B.1.

174. See infra notes 230-32 and accompanying text.

175. 96 A.2d 810 (Del. Ch. 1953).

176. See id. at 810-11.

177. See id.

178. See id. at 811 . 
more shares at its sole discretion was adopted at a shareholder vote in which the shares of Canada Southern were voted by proxy given to a director and lawyer of Manabi. ${ }^{179}$ The Buckley-Hagan rift grew deeper and Hagan resigned from his position at Canada Southern but not from Manabi. ${ }^{180}$ Hagan then engineered a board meeting of Manabi, that the Buckleys could not attend, and at which the board authorized the sale of shares representing an additional $18 \%{ }^{181}$ The Delaware Court of Chancery dismissed Manabi's claim that the issuance was driven by a need for financing, and granted Canada Southern a preliminary injunction blocking the issuance and transfer of the new shares, saying:

When the undisputed facts are viewed cumulatively I find it reasonable to infer that the primary purpose behind the sale of these shares was to deprive plaintiff of the majority voting control. Hagan and his associates did too much too soon with too little disclosure to justify a contrary conclusion. $^{182}$

The court assumed and the defense conceded that, if the issuance was motivated by a desire to deprive Canada Southern of control, it was an improper interference with shareholder voting. ${ }^{183}$

A few years later, the Delaware Court of Chancery would express its dismay at a dilutive exchange of stock in the midst of a takeover battle. The transaction in Condec Corp. v. Lunkenheimer $\mathrm{Co}^{184}$ involved an attempt of Condec to acquire Lunkenheimer through a hostile tender offer. ${ }^{185}$ Lunkenheimer reached an agreement with a friendly alternative buyer and exchanged newly issued shares with the friendly acquirer. ${ }^{186}$ Condec complained that the result of the exchange was to dilute the control of Lunkenheimer that Condec had already acquired. ${ }^{187}$ The court determined that the friendly transaction

was clearly unwarranted because it unjustifiably strikes at the very heart of corporate representation by causing a stockholder with an equitable right to a majority of corporate stock to have his right to a proportionate voice and influence in corporate affairs to be diminished by the simple act of an exchange of stock which brought no money

179. See id.

180. See id. at 812 .

181. See id.

182. Id. at 813 .

183. See id.

184. 230 A.2d 769 (Del. Ch. 1967).

185. See id. at 771 .

186. See id. at 772-73.

187. See id. at 773 . 
into the Lunkenheimer treasury, was not connected with a stock option plan or other proper corporate purpose, and which was obviously designed for the primary purpose of reducing Condec's stock holdings in Lunkenheimer below a majority. ${ }^{188}$

Thus, Condec prohibits interference with voting control. Both Canada Southern and Condec, however, dealt with situations where existing management turned against an entity that had or was about to acquire actual voting control. By contrast, Schnell v. Chris-Craft Industries, Inc. ${ }^{189}$ applies directly to the setting of a proxy fight, where the insurgents do not have voting control and are simply seeking to nominate directors opposed by management.

The management of Chris-Craft, faced with the prospect of a hostile proxy fight, moved the scheduled shareholder meeting to an earlier date. The meeting was moved by over a month, from January 11, 1972 , to December 8, 1971. ${ }^{190}$ The Delaware Supreme Court relied on the lower court's conclusions that management's actions left little chance of a successful proxy fight:

[T]hose conclusions amount to a finding that management has attempted to utilize the corporate machinery and the Delaware [1]aw for the purpose of perpetuating itself in office; and, to that end, for the purpose of obstructing the legitimate efforts of dissident stockholders in the exercise of their rights to undertake a proxy contest against management. These are inequitable purposes, contrary to established principles of corporate democracy. The advancement by directors of the by-law date of a stockholders' meeting, for such purposes, may not be permitted to stand. ${ }^{191}$

With the authority of its supreme court, Delaware repeats that no interference with shareholder voting powers will be allowed. ${ }^{192}$ This teaching was applied directly in Lerman v. Diagnostic Data, Inc., ${ }^{193}$ where management postponed the shareholder meeting, but extended the notification requirements so as to preclude the insurgent plaintiff from being able to meet them. ${ }^{194}$ Although this was not necessarily intentional, it was a sufficient interference with voting for the court to interpret the above quotation from Schnell to mean that changes in the annual

188. Id. at 777 .

189. 285 A.2d 437 (Del. 1971).

190. See id. at 438 .

191. Id. at 439 .

192. See id.

193. 421 A.2d 906 (Del. Ch. 1980).

194. See id. at 912 . 
meeting mechanism (such as its date and the notification deadline) "cannot be put into operation in such a manner that those wishing to wage a proxy fight are required to be in a state of 'shelf-readiness' in order to meet a sudden advancement of the date." thus, indicates that the corporate machinery cannot be used in such a way as to require insurgents to have all their documentation ready ahead of time (i.e., to be in "shelf-readiness") in order to wage a successful proxy fight. ${ }^{196}$

These extremely protective statements that safeguard the pure exercise of shareholder voting rights would be diluted in the mideighties. The recent cases perceive justifications for deviating from this absolute protection from interference with corporate democracy.

2. Recent Cases: Blasius and the Intermediate Standard

Delaware started qualifying the previously absolute protection of voting from interference with In re Anderson, Clayton Shareholders' Litigation. ${ }^{197}$ Despite siding with the insurgent plaintiffs, the court interjected language suggesting the possibility that the protection of the undisturbed exercise of voting was not absolute. ${ }^{198}$

The management of Anderson, Clayton suggested a recapitalization plan, on which its shareholders were to vote on June 3, 1986. ${ }^{199}$ An alternative bidder was announced to the board on May 29, and on June 2 the shareholders received proxy statements to the effect that negotiations with the hostile bidder would continue but that the recapitalization should be voted on in case the negotiations did not reach fruition. ${ }^{200}$ The vote was extended to $5 \mathrm{p}$.m. on June $5 .^{201}$ The negotiations, however, failed to proceed because the potential acquirer refused to abide by management's condition that the acquirer not pursue a hostile offer, nor challenge the recapitalization..$^{202}$ The board met on June $7 .^{203}$ Its independent directors, after hearing revised (upward) estimates of the value the shareholders would receive in the recapitalization and after

195. Id. at 914.

196. See id.

197. 519 A.2d 669 (Del. Ch. 1986).

198. See id. at 675 .

199. See id. at 672 .

200. See id. at 672-73.

201. See id. at 673 .

202. See id.

203. See id. at 674. 
hearing from financial and legal advisers of Anderson, Clayton, decided to proceed with the recapitalization. ${ }^{204}$

The court indicated that the disclosure to shareholders, that negotiations were proceeding with the potential acquirer, was misleading. ${ }^{205}$ Shareholders were led to vote in favor of the recapitalization under the impression that if a preferable outside offer materialized, it would be pursued. ${ }^{206}$ The actions of management were to prevent the outside offer. Thus, Anderson, Clayton appears to have been decided on a rationale of adequacy of disclosure. After all, Chancellor Allen writes, "what does concern me is whether the shareholders would have approved the recapitalization if they had been told ... 'we won't bother to explore the [higher outside offer]." ${ }^{207}$

The factor that makes Anderson, Clayton not a direct support of unhindered shareholder democracy is that the board could have reasonably refused to deal with the outside acquirers. If the board could fashion the restructuring so that no shareholder vote was required, it would not even have had to make the hypothetical disclosure that Chancellor Allen suggests.

The next step qualifying the right to an unhindered vote is Blasius Industries, Inc. v. Atlas Corp. ${ }^{208}$ It is important to note that Blasius did not involve an immediate threat of a hostile acquisition. The insurgents sought to increase the number of seats on the board from seven to fifteen, the maximum that Atlas's bylaws allowed, and to appoint nominees to the eight new seats. ${ }^{209}$ The change of control that would ensue would not result from a new majority control of the shares, but from a new majority on the board of directors. ${ }^{210}$

The incumbent board of directors was faced with the threat of loss of control. ${ }^{211}$ To defeat the insurgents' efforts they appointed two additional members to the seven-member board. ${ }^{212}$ Thus, even if the insurgents were able to capture the rest of the new seats, they would not have a majority. ${ }^{213}$

204. See id.

205. See id. at 677-78.

206. See id. at 678.

207. Id.

208. 564 A.2d 651 (Del. Ch. 1988).

209. See id. at 654 .

210. See id.

211. See id. at 655 .

212. Seeid.

213. See id. 
This action of the incumbents was challenged and the Delaware Court of Chancery struck the defense for unjustifiable interference with the "shareholder franchise." 214 Blasius leaves us with the idea that the board of directors cannot implement measures to distort the free exercise of the voting powers of the shareholders. In Blasius, however, this prohibition was perceived as being qualified:

In my view, our inability to foresee now all of the future settings in which a board might, in good faith, paternalistically seek to thwart a shareholder vote, counsels against the adoption of a per se rule invalidating, in equity, every board action taken for the sole or primary purpose of thwarting a shareholder vote, even though I recognize the transcending significance of the franchise to the claims to legitimacy of our scheme of corporate governance. ${ }^{215}$

In other words, the board of directors may, in exceptional circumstances, be justified in interfering with shareholder democracy. This exception that the Blasius court could not foresee-the exception to the rule prohibiting interference with the corporate franchise-would arise when the proxy fight is accompanied by a takeover that would result in concentrated ownership.

3. Proxy Fights Accompanied by Hostile Takeover Attempts: Defenses are Permitted

Chancellor Allen authored two opinions that have shaped our understanding of the reaction of Delaware courts to defenses when the target is faced by both a proxy fight and a tender offer. Both opinions come from the same dispute, the fight of Stanley Stahl over the control of Apple Bancorp. ${ }^{216}$ The Delaware Supreme Court has remained unusually silent with respect to proxy fights used in tandem with tender

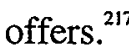

Stahl came to own 30.3\% of Apple Bancorp before Apple Bancorp considered implementing a poison pill. ${ }^{218}$ Stahl's response was to seek

214. See id. at $659-60,662$.

215. Id. at 662.

216. See Stahl v. Apple Bancorp, Inc., 579 A.2d 1115 (Del. Ch. 1990) (“Stahl I"); Stahl v. Apple Bancorp, Inc., No. CIV.A.11510, 1990 WL 114222 (Del. Ch. Aug. 9, 1990) ("Stahl Ir").

217. Not even the Delaware Supreme Court's opinion in Unitrin is relevant. The defensive measure was a response to a threat that had not materialized and it may well not take the shape of a joint tender offer and proxy fight. While the defense Unitrin allowed would concentrate ownership in a very slight degree, the company remained $72 \%$ publicly owned. See Unitrin v. Am. Gen. Corp., 651 A.2d 1361, 1378 (Del. 1995), discussed supra notes 160-62 and infra 418-22 and accompanying text.

218. See Stahl I, 579 A.2d at 1118. 
control by means of a proxy fight. ${ }^{219}$ Stahl also commenced a tender offer at $\$ 38$ per share when the shares were trading at $\$ 32^{1 / 4}$, namely for an $18 \%$ premium. ${ }^{220}$ The tender offer was conditioned on Stahl's success in the proxy fight and elimination of the poison pill. ${ }^{221}$ The board sought to improve its negotiating position by trying to find an alternative buyer and by trying to delay Stahl. ${ }^{222}$ The board had not set the date for the annual meeting but had already set a record date, that is, the date as of which share ownership determines voting rights at the meeting. ${ }^{223}$ In response to Stahl's threat, the board removed the record date. ${ }^{224}$

Stahl complained about the board's removal of the record date. ${ }^{225}$ It is important to note that in the recitation of the facts, the court stressed that Stahl responded to an inquiry of the Apple board that he was unwilling to offer to buyout Apple Bancorp at book value. ${ }^{226}$ Later, the court stressed that Stahl had not committed to using his best efforts to cash-out any nontendering shareholders in a second-step merger and that he may not even conduct a second step. ${ }^{227}$ Stahl's offer was, however, for all stock and Stahl did express an intent for a second-step cash-out merger. $^{228}$

The dynamics of this situation are delicate. An offer for part of the stock with no prospect of a buyout of the minority shares would be coercive. Shareholders would feel pressured to tender their shares for fear of being stuck with less liquid and less valuable securities after the takeover. Here the offer was for all of the stock. ${ }^{229}$ Just as in Mesa's attack on Unocal, ${ }^{230}$ the Stahl court considers coercive the absence of a guaranteed cash-out for shareholders who elected not to tender or who overlooked the offer. ${ }^{231}$

Stahl attacked the removal of the record date as an interference with shareholder voting. ${ }^{232}$ The court's response was that since the shareholder meeting had to occur by September, the board had only

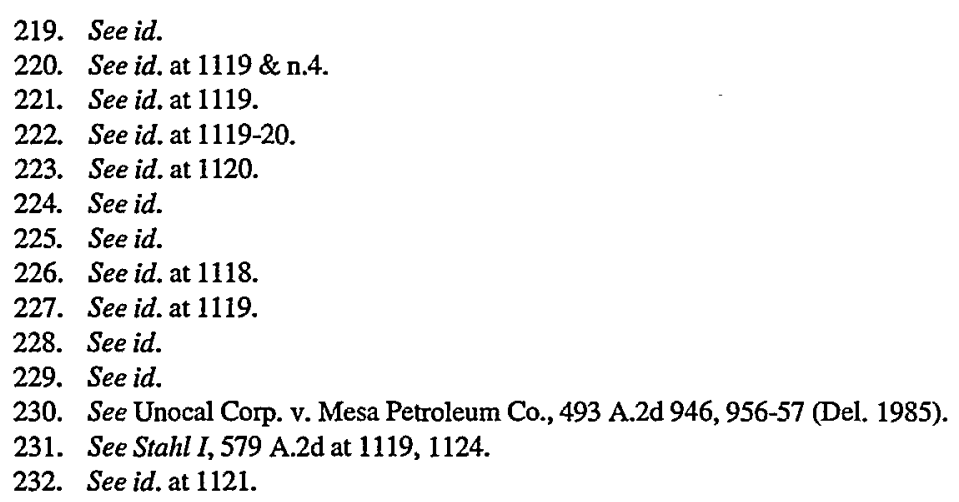


postponed the exercise of the vote without precluding a victory by Stahl, a victory which was not certain..$^{233}$ That Stahl's victory is not certain is important in order to distinguish this case from Canada Southern Oils and Condec. Both involved board actions against majority owners. ${ }^{234}$ The interference was considered improper, but the victory of the majority was certain.

Finally, the Stahl court explains that a board selling the corporation must act in an informed way. It is justified in forcing the same on the shareholders:

Were the directors to undertake to sell the company they would be obliged to act in an informed way.... Where the shareholders are in effect to be asked to decide whether the company should be sold in a given transaction, the board may properly recognize the shareholders need for information, other than the market prices of their stock, relevant to that decision. The disaggregated shareholders are incapable of obtaining appropriate information on alternatives other than the Stahl proposal and the market for their stock; only the board can accomplish that task. Thus, the absence of relevant information, in my opinion, may reasonably be seen as posing a threat to the vote of the Bancorp shareholders in the particular context presented. ${ }^{235}$

Essentially, given the threat of an uninformed shareholder decision to sell at a low price, the board's response of delaying the annual meeting was not only proportionate but, in the court's words, "extremely mild.",236

After this defeat in the Court of Chancery, Stahl attacked the term of the poison pill that Apple Bancorp had adopted. ${ }^{237}$ The pill determined beneficial ownership of stock as including any shares "which are beneficially owned, directly or indirectly, by any other person with which [the suitor] .. . has any agreement, arrangement or understanding... . for the purpose of acquiring, holding, voting or disposing of any securities of [Apple Bancorp]. ${ }^{, 238}$

Stahl was not attacking the application of this language to actual enforceable agreements regarding voting. He was attacking its terrorizing effect, which precluded him from participating in discussions that might lead to informal and nonbinding understandings regarding the

233. See id. at 1123 .

234. See supra notes $175-88$ and accompanying text.

235. Stahl I, 579 A.2d at 1124 (citations omitted).

236. Id.

237. See Stahl II, 1990 WL 114222 , at *2.

238. Id. at $* 3$ (second omission in original). 
election. ${ }^{239}$ Effectively, Stahl could not talk about Apple Bancorp with a friend who owned any of its stock ${ }^{240}$ lest the friend be deposed and state that Stahl's proposals sounded reasonable and that an understanding had been reached that the friend would support Stahl.

Stahl was effectively conceding that the board needed time to find an outside buyer, as was the premise of his defeat in Stahl $I^{241}$ Since nonbinding understandings between shareholders have no effect on the board's ability to find an outside buyer, how could this restriction be reasonable?

The court's response was that an outside deal was not the only way to improve shareholder value. The board could also try to extract a higher price from Stahl himself. When negotiating with Stahl, however, the board would be limited by Stahl's perception of his likelihood to succeed at the current price. Essentially, if $21 \%$ of the shareholders were to tell Stahl that they found his current offer acceptable and would vote for it, Stahl would have no incentive to increase his bid. To this effect, the court quoted the board's investment banker: "'[]]f Stahl is able to lock up enough votes, the Board will lose any ability to extract a higher proposal from Stahl.

The court is clearly saying that it allows the interference of the board with the shareholders' decision to sell the corporation because it is in the shareholders' own interests. ${ }^{243}$ The factual setting of Stahl is a world away from the factual setting of Blasius because no uninformed sale was feared in Blasius. The change of control that would take place in Blasius was one where no sale was involved and where dispersion remained constant. ${ }^{244}$

In sum, Delaware law, despite its circuitous route, appears consistently motivated by a simple concern: that transactions which concentrate dispersed ownership are problematic. Faced with a concentrating hostile threat, management can adopt powerful defensive tactics. Faced with a managerial attempt to concentrate ownership, minority shareholders receive powerful weapons. Accordingly, the treatment of proxy fights depends on their substantive outcome. Proxy fights that do not involve attempts to concentrate ownership are

239. See id.

240. Actually, since Stahl owned $30.3 \%$, his conversant had to own $0.7 \%$ or more to put the two together over the threshold of increasing Stahl's voting power past the next percentage point. See Stahl 1, 579 A.2d at 1118.

241. See id. at 1123 .

242. Stahl II, 1990 WL 114222, at *4 (quoting Mr. Jackson of Donaldson, Lufkin \& Jenrette).

243. See id. at $\approx 7$.

244. See Blasius Indus., Inc. v. Atlas Corp, 564 A.2d 651, 654 (Del. Ch. 1988). 
facilitated. Proxy fights that would lead to concentrated ownership allow management a strong response.

It is interesting to note that European attitudes, as varied as they are, lie quite far from the protection to incumbent management that Delaware provides. ${ }^{245}$ The next section provides a brief overview of

245. The positive thesis of this Article was explored above using the conventional approach of legal scholarship, examining each case closely. All the significant opinions about defenses that have been produced by the Delaware courts were examined, although some more closely than others. Other opinions consistent with this thesis may exist outside the set of defense cases, but those were not discussed.

In particular, the one consistent opinion that stands out is Smith v. Van Gorkom, 488 A.2d 858 (Del. 1985), where the directors were held personally liable for selling the corporation for too low a price to a concentrated acquirer that pushed the transaction too fast and aggressively. See id. at 874 . The court practically goes so far as to say that the board's responsibility is to protect the shareholders from such pressures at times that the stock price is depressed:

[T] he fact of a premium alone does not provide an adequate basis upon which to assess the fairness of an offering price. Here, the judgment reached as to the adequacy of the premium was based on a comparison between the historically depressed [target corporation] market price and the amount of the ... offer. Using market price as a basis for concluding that the premium adequately reflected the true value of the Company was a clearly faulty, indeed fallacious, premise.... The record is clear that before September $20, \ldots$ members of [the target]'s Board knew that the market had consistently undervalued the worth of [the target]'s stock, despite steady increases in the Company's operating income in the seven years preceding the merger.

Id. at 875-76. A dispersed buyer, of course, could have used stock as consideration. The result would be that instead of a false price, the shareholders would have to allege both a false exchange ratio (price) and a bad strategy. Claiming only that the price was too low would be insufficient because the directors could argue that the strategic success of merger was underestimated by the market and the future success of the merged entity was determined to be adequate in the informed business judgment of the directors. The larger the target as a part of the combined entity, the stronger this defensive argument becomes because it is assisted by the fact that the influence of the value of the acquired firm on the value of the whole increases. The directors of the target are the best judges of this, of course, because it is value that flows from the target. An example will illustrate.

Suppose that the target is worth $\$ 150$ but the market values it at $\$ 85$. The Van Gorkom facts would have the directors sell it for $\$ 100$ cash and be liable for not selling it for $\$ 150$. Compare this, however, to agreeing to a merger the terms of which would have the firm's shareholders receive 100 shares of the combined entity, which are valued by the market at $\$ 85$. When the shareholders make the same complaint, the directors can argue that the true value of their stake is greater, say $\$ 150$. Moreover, the directors would argue that the combination offers a unique opportunity that makes the value that the shareholders receive greater even than the $\$ 150$ that they should get in cash. Consider the strength of these arguments if the other merging corporation's shareholders will hold 900 shares, 100 shares or 10 shares in the merged firm. Our shareholders would hold, respectively, $10 \%, 50 \%$, and $89 \%$ of the merged firm in these cases. One may doubt the directors' views about the combined firm if the part of it they know best is $10 \%$ of the whole, but their credibility increases vastly when they vouch for $90 \%$ of it.

On the whole, the bias against dispersion was dominant in these cases and present in practically every case examined in this Article. My thesis is proven, unless a similarly important group of Delaware cases can be shown to have a bias in favor of concentrated acquirers. 
European jurisdictions' reactions to control contests. It is clear that the push is for more easily contestable control, but the reader must remember that European capital markets do not start from the dispersed ownership common in Anglo-American jurisdictions. ${ }^{246}$ Thus, the common goal may well be for Europe to achieve the dispersed ownership that failed to develop spontaneously. In Europe hostile acquisitions may provide a hope for the achievement of dispersed ownership.

\section{European Attitudes: Easy Acquisitions from Concentrated Owners}

Corporate combinations must be put in perspective by noting the background of ownership structure in which they operate. The United States and the United Kingdom, and to a lesser extent perhaps Canada and Australia, all approach corporate defenses via a structure of ownership where not only majority stakes, but even large shareholders are rare. ${ }^{247}$ To this we must not forget to add a vibrant environment of corporate formation. Many of the largest U.S. corporations were not in existence thirty years ago. ${ }^{248}$ For example, CISCO Systems, Microsoft,

This is unlikely because all the major takeover cases were covered above, as shown by the fact that the leading casebook on mergers and acquisitions law, by Professors Ronald Gilson and Bernard Black, has Delaware court opinions in two chapters, "17: Corporate Law Concerns in Hostile Transactions," and "19: Corporate Law Concerns in Friendly Acquisitions." The cases reviewed in the casebook are Cheff v. Mathes, 199 A.2d 548 (Del. 1964); Unocal Corp. v. Mesa Petroleum Co., 493 A.2d 946 (Del. 1985); Moran v. Household International, Inc., 500 A.2d 1346 (Del. 1985); City Capital Associates Limited Partnership v. Interco, Inc., 551 A.2d 787 (Del. Ch.), appeal dismissed, 556 A.2d 1070 (Del. 1988); Paramount Communications, Inc. v. Time, Inc., 571 A.2d 1140 (Del. 1989); Smith v. Van Gorkom, 488 A.2d 858 (Del. 1985); Revlon, Inc. v. MacAndrews \& Forbes Holdings, 506 A.2d 173 (Del. 1986); Mills Acquisition Co. v. Macmillan, Inc., 559 A.2d 1261 (Del. 1988); and Paramount Communications, Inc. v. QVC Network, Inc., 637 A.2d 34 (Del. 1993). See generally GILSON \& BLACK, supra note 16. The only one of these cases that was not discussed in this Article is Macmillan, because it deals with favoritism during an auction process rather than the unfolding of a hostile confrontation. See Macmillan, 559 A.2d at 1264.

In other words, this Article's exposition is objective.

246. See Clas Bergström et al., The Regulation of Corporate Acquisitions: A Law and Economics Analysis of European Proposals for Reform, 1995 CoLuM. BUS. L. REV. 495, 498 n.11.

247. See id. at $498 \&$ n.11, 502.

248. The venerated venture capitalist, Arthur Rock, recounts the creation of Fairchild Semiconductor, in 1957, and the founding of Intel, in 1968, by Rock and two of the "Fairchild Eight" founders. See Arthur Rock, Arthur Rock \& Co., in DONE DEALS: VENTURE CaPITALISTS TELL THEIR STORIES 139, 140, 144-45 (Udayan Gupta ed., 2000). Of course, Fairchild Semiconductor being the progenitor of venture capital, was not financed by an organized group, but by a corporation of an individual investor, Sherman Fairchild. See id. at 141. A few years later Rock invested "the princely sum of $\$ 60,000$ " in a company being started by "Steve Jobs and Steve Wozniak[, who] weren't very appealing people in those days." Id. at 146, 145. That company was Apple. It was founded in 1976. See Jane M. Rolling, Comment, No Protection, No Progress for 
Apple, Oracle, and Dell are corporate giants despite being newborn compared to the established corporations of continental Europe. Moreover, in the economies that produce these breakneck speeds of corporate growth, corporate formation has created a new industry. The venture capital that feeds the seedlings, some of which grow to these dimensions, is an industry into itself. . $^{249}$

To this we must juxtapose the continental European environment. The norm in continental Europe is concentrated ownership, the usual presence of a majority owner, the frequent use of capital structures that preserve control (pyramids in Italy, ${ }^{250}$ interlocking stakes and directorates in France, ${ }^{251}$ and dual class capitalizations in Greece and Sweden ${ }^{252}$ ). The replication of the venture capital atmosphere has been achieved only lately. Neither the German Neuer Markt nor the French Nouveau Marché, which were to emulate NASDAQ's ability to foster venture capital by allowing early public offerings, have yet to produce corporations of a size comparable to the largest American venture capital success stories. ${ }^{253}$

These dramatically different backdrops matter for the law regarding takeovers and defensive measures. Hostile acquirers can have concentrated ownership as well as dispersed ownership. When dispersed ownership is abundant and is continuously created in new corporations, the legal and economic system feels little pressure to ensure that the hostile offers from dispersed owners are not impeded. By contrast, in a system where dispersed ownership is rare, the possibility of hostile acquisitions by dispersed owners may be a meaningful avenue for inducing the dispersed ownership that the legal and economic system has been unable to produce in the stages of corporate formation and growth. It is against this dramatically different potential to generate new corporations of dispersed ownership that the attitudes of European laws

Graphical User Interfaces, 2 MARQ. INTELL. PROP. L. REV. 157, 162 n.26 (1998). Mitch Kapor founded Lotus in 1981. See Mitch Kapor, Accel Partners, in Done DEALs, supra, at 83, 85.

249. In 1997, Venture Capital funds had over $\$ 50$ billion in assets (held and promised). See Paul A. Gompers \& Josh Lerner, The Venture CAPITAl CyCle 5 (1999).

250. See Marco Pagano et al., The Market as a Source of Capital: Some Lessons from Initial Public Offerings in Italy, 40 EuR. ECON. REv. 1057 passim (1996); Marco Pagano et al., Why Do Companies Go Public? An Empirical Analysis, 53 J. Fin. 27, 31 (1998).

251. See, e.g., Lauren J. Aste, Reforming French Corporate Governance: A Return to the TwoTier Board?, 32 GEO. WASH. J. INT'L L. \& ECON. 1, 18 (1999).

252. See HOLMEN \& HÖGFELDT, supra note 34, at 3-4.

253. See Vanessa Fuhrmans, Playing by the Rules: How Neuer Markt Gets Respect, WALL ST. J., Aug. 21, 2000, at C1. In three years the Neuer Markt has increased to 302 traded corporations with capitalization of $\$ 172$ billion. See id. That is still less than a third of the capitalization of Apple Computer, Cisco, Dell, and Gateway. See infra note 313. 
toward defenses must be analyzed. Three interesting facets appear in EU law, the Proposed Thirteenth Directive, the Proposed Fifth Directive, and some tax developments.

\section{The Star-Crossed Thirteenth Directive}

After wrangling over takeover defenses since 1989, the European Union Council of Ministers produced direct takeover regulation through the Thirteenth Directive on Company Law and Takeover Bids. ${ }^{254}$ Formerly, the dominant feature of the Proposed Thirteenth Directive was an obligation on a buyer to offer to buy $100 \%$ of the target when the buyer's ownership exceeds one-third (33.3\%) of the voting power of the target. ${ }^{255}$ In the final version of the directive, the threshold for an obligation to bid for the minority shares has been raised to a controlling stake. ${ }^{256}$ This is, in effect, an obligation that leads to the sharing of the control premium with the minority, which hinders acquisitions that increase productivity. ${ }^{257}$

254. See Proposed Thirteenth Council Directive on Company Law Concerning Takeovers and Other General Bids, 1989 O.J. (C 64) 1 [hereinafter Thirteenth Directive]; Amended Proposal 1990 O.J. (C 240) 1; Amended Proposal, COM(95)655 final at 1-4 [hereinafter Amended Thirteenth Directive], available at http://www3.europarl.eu.int/dg7/doclegcons/data/word/1995/0341/1995034 1(COD)-PE2-en.doc (last visited Feb. 6, 2002). A new final version passed the Council of Ministers. See EU Passes 13th Directive, FIN. TIMEs (London), June 20, 2000, at 28. It subsequently was amended by the European Parliament in such a way that its implementation became again unlikely. See Paul Meller, Europe Move on Hostile Takeovers is Faulted, N.Y. TIMES, Dec. 14, 2000, at W1.

255. See generally Thirteenth Directive, supra note 254 , passim.

256. Article 5, paragraph 1 of the proposed directive, as amended by the European Parliament on December 13,2000, reads:

Where a natural person or legal entity ... [or group] holds securities of a company ... which ... confer[ on him the control of that company, Member States shall ensure that rules are in force which oblige this person to make a bid as a means to protect the minority shareholders of that company. This bid shall be addressed to all holders of securities for all their holdings at an equitable price. An equitable price is at least the highest price paid by the offeror ... in the twelve months preceding disclosure of the bid.... When the consideration offered by the offeror does not consist of liquid securities admitted to trading on a regulated market, such consideration has to include a cash consideration at least as an alternative.

Amended Thirteenth Directive, supra note 254, art. 5, para. 1.

257. An obligation to make a bid for $100 \%$ of the target company is a sensitive subject because it is equivalent to an obligation to share the control premium, i.e., the amount above the market price that is paid because this block of shares is not simply a passive investment but allows its holder to control the company. Sharing the control premium has been shown to prevent productivity-increasing purchases of control. See Lucian Arye Bebchuk, Efficient and Inefficient Sales of Corporate Control, 109 Q. J. ECON. 957, 984-87 (1994). If the premium is shared, a buyer who will not extract private benefits of control but is slightly more skilled than the current controller, cannot make an offer to the current controller if the controller extracts significant private value from control. The owner of control will demand compensation for the private benefits to be 
As passed, the primary thrust of the Thirteenth Directive was to prohibit defensive measures after a takeover bid is imminent. ${ }^{258}$ Thus, the Thirteenth Directive expands Rule 21 of the Takeover Code of the City of London to apply throughout the European Union. This form of the Thirteenth Directive would prohibit defensive issuance of securities, defensive transactions that would significantly alter assets or liabilities of the company, and defensive repurchases.

The European Parliament, however, thwarted these plans. According to the early reports of the press, it not only reinstated management's ability to resist hostile offers without a shareholder vote, but it also imposed an obligation to consult with their unions when negotiating. ${ }^{259}$ Naturally, the prospects for reconciling these two diametrically opposed positions through the European Union Commission were considered unlikely. ${ }^{260}$

\section{The Proposed Fifth Directive}

The Fifth Directive on Company Law has been discussed without being adopted since $1972 .{ }^{261}$ In its original form it injected employee participation in corporate governance. ${ }^{262}$ The German model of "co-

foregone, but the sharing rule would force the buyer to compensate all shareholders the same way. Therefore, a premium-sharing rule is ill-advised.

258. The obligation for hostile bids to reach shareholders remains in the Thirteenth Directive, although muted by the addition of the interests of the constituencies. For example, article 3 , paragraph 1(c) of the version passed by the Council on June 19,2000 read "the board of an offeree company is to act in the best interests of the company as a whole, and must not deny the holders of securities the opportunity to decide on the merits of the bid." Proposed Thirteenth Council Directive on Company Law Concerning Takeovers and Other General Bids, art. 3, para. 1(c), 2001 O.J. (C 23) 4, available at http://europa.eu.int/eur-lex/pri/en/oj/dat/2001/c_023/c_02320010124en00010 014.pdf (last visited Feb. 22, 2002). The version passed by the European Parliament on December 13,2000 amended the above to read:

[T] he board of an offeree company is to act in the interests of the company as a whole, in particular in the interests of corporate policy and its continuation, shareholders and staff, and with a view to safeguarding jobs, and must not deny the holders of securities the opportunities to decide on the merits of the bid.

Amended Thirteenth Directive, supra note 254, art. 3, para. 1(c).

259. See Meller, supra note 254.

260. See id.

261. For a history of the Fifth Directive, see J.J. Du Plessis \& J. Dine, The Fate of the Draft Fifth Directive on Company Law: Accommodation Instead of Harmonisation, 1997 J. BuS. L. 23.

262. This is, of course, still the focus of the directive. Even as it has been amended, the directive would still oblige every European legal system to provide the option of a two-tier system akin to the German system-of an executive board and a supervisory board with worker participation. Article 2, section 1 provides that:

The Member States shall provide that the company shall be organized according to a two-tier system (management organ and supervisory organ) in accordance with Chapter III. They may, however, permit the company to have a choice between a two-tier system 
determination" is that of a supervisory board, senior to the board of directors, with equal shareholder and worker representation. ${ }^{263}$ The polar opposite experience of the United Kingdom does not mandate the involvement of employees in the administration of the corporation. The vastly different attitudes on this matter still prevent its adoption.

The Fifth Directive would not seem to involve takeovers, but in its third amendment, of November $1991{ }^{264}$ it would prevent dual class common stock as a defensive strategy. ${ }^{265}$ The bar on dual voting power stock would extend to all corporations whether incorporated before or after the adoption of the Fifth Directive. ${ }^{266}$

The prohibition on dual voting power recapitalizations is a repeated theme in European law. ${ }^{267}$ It also appears in the proposed legislation for the supranationally-chartered Societas Europae. ${ }^{268}$ Action on this matter, however, is unlikely because of the sharply divergent views of the members. The Fifth Directive is an example of what many EU states would like to advance as a proposed bar on takeover defenses, but one where the current impasse is unlikely to be overcome soon.

organized in accordance with Chapter III and a one-tier system (administrative organ) in accordance with the provisions of Chapter IV.

Amended Proposal for a Fifth Directive Founded on Article 54(3)(G) of the Treaty Concerning the Structure of Public Limited Companies and the Powers and Obligations of their Organs, 1983 O.J. (C 240) 2 [hereinafter 1983 Fifth Directive].

263. See Henry Hansmann \& Reinier Kraakman, The End of History for Corporate Law, 89 GEO. L.J. 439, 445 (2001).

264. See COM(91)372 final, art. 33.

265. The proposed Fifth Directive creates a presumption against stock with dual voting power and requires statutory authorization of dual voting power:

(1) The shareholder's right to vote shall be proportionate to the fraction of the subscribed capital which the shares represent.

(2)... The laws of the Member States may authorize the memorandum and the articles of association to allow:

(a) restriction or exclusion of the right to vote....

Id. Moreover, additional voting shares cannot be issued in a hurry for defensive purposes because section 3 of article 3 requires a one month prepayment for the exercise of the right to vote: "Any shareholder who, at the date of the general meeting, has not paid up calls made by the company at least one month earlier may not exercise his right to vote." Id.

266. The 1983 version of the proposal, unchanged by the 1991 amendments, requires that all firms be subject to the Fifth Directive, even if incorporated before its adoption, with a transition period of eighteen months (and up to four years for the two-tiered board): "The Member States may provide that [the rules governing the directive] shall not apply to companies already in existence until the end of a period of 18 months ...." 1983 Fifth Directive, supra note 262, art. 64.

267. See Deirdre Curtin \& John Davies, Capital Structures Threatened, FIN. TIMEs (London), Feb. 6, 1992, at 10.

268. See id. 
3. Tax Developments

In addition to the direct prohibition of defensive measures, takeovers in Europe are facilitated by tax rules, such as article 4 of the Directive on the Taxation of Cross-Border Mergers, ${ }^{269}$ which prevents the merger from being a tax event if certain conditions are met. Thus, both the shareholders and the corporations that merge will not realize gains leading to a tax liability because of the merger.

A dramatic change is in the process of being implemented in Germany. A tax reform abolishes all long-term capital gain taxation for stock owned by corporations. ${ }^{270}$ According to arguments for this change, it aspires to break cross-holdings and to allow large banks to divest from their stake in firms that they have financed decades ago. ${ }^{271}$ Crossholdings and large bank ownership are accused of stifling the operation of corporate governance, of preventing the smooth operation of the equity markets, of hampering the development of the market for younger companies and venture capital, and of lending an incestuous aura to the relation between banks and industrial firms. ${ }^{272}$

If it operates as intended, the elimination of capital gains liability will remove a huge impediment on divestitures. Since friendly mergers would practically always be nontaxable, ${ }^{273}$ this change will be felt primarily in the context of hostile acquisitions. While the concentrated ownership indicated by accounts from the early nineties has already eroded significantly, cross-ownership stakes are still very significant. ${ }^{274}$

269. See Council Directive 90/434/EEC of 23 July 1990 on the Common System of Taxation Applicable to Mergers, Divisions, Transfers of Assets and Exchanges of Shares Concerning Companies of Different Member States, art. 4(1), 1990 O.J. (L 225) 1, 5 ("A merger or division shall not give rise to any taxation of capital gains calculated by reference to the difference between the real values of the assets and liabilities transferred and their values for tax purposes."), available at http://europa.eu.int/smartapi/cgi/sga_doc?smartapi!celexapi !prod!CELEXnumdoc\&lg=EN\&num doc $=31990$ L0434\&model=guichett (last visited Dec. 31, 2001).

270. The proposed provision is part of the 2000 Tax reform (Steuerreform 2000). It reads in the relevant part "[i]n determining the income, gains from the sale of an interest of the corporation in another corporation or partnership ... shall not be considered income." See §8b Körperschaftssteuergesetz in der Fassung der Bekanntmachung vom 22.April 1999 (BGB1. 1999 Teil I S. 817) (translation of Leo Plank). A description of the tax reform in English is available at http://www.bundesfinanzministerium.de/infos/taxref.pdf (last visited Aug. 29, 2000), where the reference to the elimination of capital gains from corporate cross ownership appears on page 2 .

271. See Ronald J. Gilson, Globalizing Corporate Governance: Convergence of Form or Function, 49 AM. J. COMP. L. 329, 342 (2001).

272. See Towards an Easing of Fiscal Policies in Europe?, BANQUE PARIBAs CONJONCTURE, Dec. 31, 2000, at 13 .

273. See Walter D. Schwidetzky, A Comparison of Corporate Taxation in the United States and Germany: Different Ways Up the Mountain, 28 GA. J. INT'L \& COMP. L. 217, 240 (2000).

274. DaimlerChrysler's ownership dispersion has been significantly increased by the merger of Daimler-Benz with Chrysler. For example, Mark Roe reports that Deutsche Bank had a 28\% stake 
It is wrong, however, to conclude that cross-ownership and large stakes render European corporations invulnerable to hostile takeovers. The dual phenomenon of large aggregate stakes held by U.S. institutional investors and of the possible defection of traditionally friendly shareholders, has recently shown that firms of conventional European-style concentrated ownership may be vulnerable to hostile acquisitions. ${ }^{275}$ This possibility suggests that European companies may suddenly find that they are significantly more vulnerable than U.S. corporations.

In sum, the review of U.S. and EU defense law shows mirror images. The European Union inhibits defenses while Delaware gives directors ample authority to implement defensive measures. This difference, however, in the substantive law may well produce the same substantive outcome, namely greater dispersion of ownership. The U.S. defenses protect the dispersed ownership that arises spontaneously in the process of corporate formation, while the EU lack of defenses allows takeovers to disperse the concentrated ownership that seems endemic in the economies of continental Europe. The question, thus, becomes whether dispersed ownership is a valuable goal, and by what methods it should be pursued.

\section{WHY DISPERSED OWNERSHIP WITH SEMI- ENTRENCHED CONTROL?}

Dispersed ownership appears as such a consistent choice that it seems to be a fundamental goal of corporate law at the turn of the new millennium. The economic motivations of dispersed ownership are, therefore, an important topic. Only by understanding the function of dispersed ownership can a cogent critique of the legal system be made, and only in view of the goal of dispersed ownership can academic criticism provide constructive proposals. Until now, academic criticism of corporate law has seemed unrelated to the actual choices of judges

\footnotetext{
in Daimler-Benz in 1990, which had by 1999 turned into a $12 \%$ interest in the combined entity, followed by the Emirate of Kuwait with 7\%. See Mark J. Roe, Some Differences in Corporate Structure in Germany, Japan, and the United States, 102 YALE L.J. 1927 app. at 1998 tbl.VIII (1993); see also DAIMLERChRYSLER AG, 1999 ANNUAL REPORT 63 (1999) (reporting that Deutsche Bank's stake decreased from $22 \%$ to $12 \%$ as a result of the merger, and Kuwait's from 13\% to 7\%), available at http://www.daimlerchrysler.de/investor/reports/annua199/download/20_F. pdf (last visited Aug. 31, 2000); DaimlerChrysler Investor Relations, at http://www.daimlerchrysler.com/index_e.htm?/investor/meeting2000/hvglossar_e.htm (last visited Aug. 31, 2000).

275. The same view is offered and elaborated by Tim Jenkinson \& Alexander Ljungqvist, The Role of Hostile Stakes in German Corporate Governance, 7 J. CORP. FIN. 397 (2001).
} 
and legislators. ${ }^{276}$ The tools of the academy appeared insensitive to the goals and aspirations of the policymakers.

Dispersed ownership, however, is beneficial. To see these benefits, it is important to juxtapose the dispersed ownership that defensive tactics allow with the alternatives that might replace dispersed ownership if the control it conferred were too ephemeral. To do this we must examine the controllers' incentives at the moment the firm goes public and at the moment divisions may be spun off as independent companies. The initial public offering of a firm's stock is crucial because the controller's incentives determine the shape that public ownership will take. ${ }^{277}$ The spin-off decision is important because it requires that the instinct for empire-building and conglomeration that would lead top management to retain control has been countered. Of course, these decisions are also determined by the price that buyers are willing to pay for the stakes being sold, the shares offered to the public, and the shares of the spun-off subsidiary. Contrary to the expectations of the legal academy that shareholders would prefer defenseless firms, we consistently see savvy entities making public offerings of firms with takeover defenses. ${ }^{278}$ This suggests that the market forces favor takeover defenses and empirically bolsters the arguments in favor of the dispersed ownership they preserve.

Numerous advantages flow from dispersed ownership that is combined with the semi-entrenched control of Delaware defenses. First we will examine the fact that dispersed ownership is a condition for the vitality of equity markets. Without dispersed ownership equity markets will not become the arbiters of control, power, and capital allocation that they are in the United States and the United Kingdom, nor will they offer investors the possibility of investment at a reduced-risk through diversification. Unless control has some permanence, entrepreneurs would resist dispersing their ownership, and the attractiveness of venture capital would be weakened.

276. See, e.g., Michael R. Klein, Takeover Abuses Demand Congressional Reform, LEGAL TIMES, June 25, 1984, at 12 .

277. See, e.g., Curtis J. Milhaupt, The Market for Innovation in the United States and Japan: Venture Capital and the Comparative Corporate Govemance Debate, 91 Nw. U. L. REV. 865,868 n.14, 883 (1997).

278. Several studies report that firms go public with defensive measures as part of their corporate machinery, and even more so when backed by venture capitalists. See COATES, supra note 3, at 60; DAINES \& KLAUSNER, supra note 3, at 4. 


\section{A. Dispersed Ownership with Semi-Entrenched Control as a Precondition for the Vitality of the Equity Markets}

Well-functioning equity markets are vital for the economy's productivity. They provide firms with cheap capital. ${ }^{279}$ They allocate capital among competing users. Most importantly, they reward entrepreneurs for their success, and by allowing diversification, they enable risk-neutral management of society's resources. ${ }^{280}$ Dispersed ownership and takeover defenses that bestow semi-entrenched control are instrumental for the vitality of equity markets.

\section{Dispersed Ownership as a Condition for Diversification}

If we study the ills of concentrated ownership, the necessity of dispersed ownership for the good functioning of equity markets becomes obvious. Two forms of concentrated ownership are possible. Concentrated ownership implies that each corporation's stock is owned by few individuals. The corporations in the economy, therefore, may be owned by a small set of individuals. This setting, where a narrow group of people own all the corporations, can be termed "narrow ownership." The second setting of concentrated ownership would have a broad segment of the population own stocks, the same number of investors as under dispersed ownership. Each investor, however, would hold shares in few corporations. This can be termed "broad undiversified ownership."

Narrow ownership implies a concentration of power and control of resources entirely unlike the American capitalist experience. Such situations appear to exist in developing economies and are followed by a host of ills. The narrow ownership of equity securities implies little interest in trading them. The result is that equity markets atrophy. Without equity markets there is no objective mechanism for monitoring managerial performance. ${ }^{281}$ Moreover, even if wealth is evenly distributed initially, the skewed distribution of power and control will soon lead to a biased distribution of wealth and to nepotism. Nepotism

279. See Bernard S. Black, The Legal and Institutional Preconditions for Strong Securities Markets, 48 UCLA L. REV. 781, 835 (2001).

280. See id. at 831-38.

281. The equity markets serve as an indicator of the confidence that traders have in the future performance of the corporation. See id. at 842 . In this way, the stock price reflects the market's assessment of managerial competence. See id. at 843 . Other mechanisms of assessing competence, such as internal reviews or governmental supervision, may be flawed themselves and thus fail to determine incompetence. Despite the errors to which the markets occasionally fall, they present a much more objective assessment. 
prevents a meritocratic assignment of control of resources to the most skilled. Moreover, the narrow dispersion of control suggests that society is less diversified with respect to the managers of its resources. It is both exposed to more downside risk and less likely to make the rare innovation. $^{282}$

The second alternative implies a broad group of investors, but each one holding a portfolio that is divided among fewer corporations. Thus, investors are less diversified than they would be under more dispersed corporate ownership. This reduced diversification means that investors bear more idiosyncratic risk. Unlike well-diversified investors, they are more exposed to the vagaries of chance that befall the few corporations that they own. The influence of luck on a single firm has a minute impact on a well-diversified portfolio, where each firm constitutes a very small fraction of the whole. The bad luck of some firms will be counterbalanced by the good luck of others. The portfolio as a whole will have diversified idiosyncratic risk away, and will only be subject to economy-wide shocks. ${ }^{283}$ The reduction in risk that comes with diversification implies that the equity market is a more attractive investment vehicle, meaning that investors are willing to bid prices up and accept slightly reduced returns. Reduced returns for investors means reduced cost of capital for firms. The reduction of the cost of one of the inputs to production means greater economic productivity. Thus, dispersed ownership leads to increased productivity.

\section{Dispersed Ownership as a Condition for Risk-Neutral Management of Social Resources}

The diversification to which dispersed ownership leads has an even more important function for social welfare. Generally, individuals are

282. The narrow ownership of stock and, hence, control, implies that the decisions regarding the actions of this society's corporations are made by a narrower group of individuals than in a society with broader ownership. The result is that society's economic resources are managed by fewer people. Good and bad luck falling on any one of the managerial class has a greater impact on social welfare than if control were more broadly dispersed. More importantly, however, the smaller number of managers suggests that society is less likely to make the rare breakthroughs. If achieving a managerial breakthrough is a chance occurring once in a million management years, a society with a million managers will average one every year, while one with a hundred thousand managers only one every ten years. Already this is a dramatic effect, but it is accentuated by the performance of the market. As soon as a firm makes a breakthrough that the market recognizes, its stock price will reflect its greater prospects and its higher-priced stock will allow it to extend its influence by using it as consideration for acquiring resources. Furthermore, other firms are more likely to notice and emulate the breakthrough if it is signaled by a high-flying stock.

283. For a general introduction to diversification, see GILSON \& BLACK, supra note 16, at $81-100$. 
risk-averse. ${ }^{284}$ Aversion to risk implies that undiversified ownermanagers would give up some returns in order to make the expected returns less risky. When the firm is owned by investors who are diversified, the firms' owners are risk-neutral. They are willing to have firm managers take cost-justified gambles. The winning gambles cancel out the losing gambles and investors' diversified portfolios follow the average, in other words, enjoy the expected return. Risk-neutral investors would not favor managerial efforts to give up returns in order to reduce risk. The owners' preferences are converted into explicit and implicit incentives for firms' managers. Managers, for example, are given options as part of their compensation packages. The value of options increases with the firm's risk..$^{285}$ Managers are thus given an incentive to increase the firm's risk that will, hopefully, overcome their risk-aversion. ${ }^{236}$ The market for control provides one more background inducement of risk-neutrality. Managers who give up returns are punished with lower stock prices that expose them to a contest for control. As long as defenses are not so strong as to provide them with entrenched control, the risk-averse managers may be replaced.

Overcoming risk-aversion, to which dispersed ownership leads, is enormously important for society. Risk-neutrality is much more than a change in preferences. Risk-neutral management of social resources directly increases their productivity. Society as a whole is diversified because its productivity depends on every one of its industries. A device which switches management of social resources from risk-aversion to risk-neutrality is a revolutionary improvement in society's prospects. Dispersed ownership is exactly such a device.

\section{Dispersed Ownership as a Condition for Liquid and, Hence, Efficient Capital Markets}

Once the market becomes an attractive investment vehicle because of the diversification that dispersed ownership allows, the quality of the equity market will also improve. The investment-driven trading activity produces liquidity which allows existing informed traders to make larger trades and attracts more informed investors (rational speculators) to the market. The increased competitive informed trading leads to greater

284. See John W. Pratt, Risk Aversion, in 3 The New Palgrave Dictionary of Money \& FINANCE 365 (Peter Newman et al. eds., 1992) (defining a risk-averse individual as "one who always prefers the expected value of a monetary gamble to the gamble itself').

285. For a very readable primer on options, see GILSON \& BLACK, supra note 16, at 231-52.

286. Evidence indicates that options do achieve this goal. See supra note 16 and accompanying text. 
accuracy of prices. $^{287}$ The market takes one step closer to perfect efficiency. Investors, however, are not indifferent to the increased price accuracy. It consists of a further reduction in risk for them, leading to further reduction in firms' cost of capital and more investment trading (uninformed trading).

The explanation of this chain reaction starts with the realization that diversification brings additional funds to the market. ${ }^{288}$ The additional funds are a result of two functions of diversification. First, it reduces the risk of the investment in the stock market for the investor. ${ }^{289}$ The result is that funds that the investor would shelter from the higher risk, the investor becomes willing to make part of a diversified portfolio. The second way by which diversification increases funds invested in the market is even more pronounced. If diversification is not available within the market, then investors will obtain diversification outside it, by considering the stock market as only one of the investments across which they could diversify. An example would be to consider an investment in the stock market in the late nineteenth century, when it was dominated by railroad stocks. ${ }^{290}$ At that time, even an investment in every stock did not provide the investor with diversification comparable

287. I have repeatedly explained the upward spiral from liquidity to more competitive informed trading to more accurate prices, lower risk for investors, and more investor trading (meaning more uninformed trading) which leads back to greater liquidity. See Nicholas L. Georgakopoulos, Frauds, Markets, and Fraud-on-the-Market: The Tortured Transition of Justifiable Reliance from Deceit to Securities Fraud, 49 U. MIAMI L. REV. 671, 685 (1995) [hereinafter Georgakopoulos, The Tortured Transition]; Nicholas L. Georgakopoulos, Insider Trading as a Transactional Cost: A Market Microstructure Justification and Optimization of Insider Trading Regulation, 26 CONN. L. REV. 1, 31-32 (1993) [hereinafter Georgakopoulos, Insider Trading Regulation]; Nicholas L. Georgakopoulos, Why Should Disclosure Rules Subsidize Informed Traders?, 16 INT'L REV. L. \& ECON. 417, 424 (1996) [hereinafter Georgakopoulos, Informed Traders]. My work has been cited by the SEC to the United States Supreme Court, and the Court accepted the argument without citation. See Petitioner's Brief at 31, United States v. O'Hagan, 521 U.S. 642 (1997) (No. 96-842) (citing Georgakopoulos, Insider Trading Regulation, supra, at 31-32); see also United States v. O'Hagan, 521 U.S. 642, 657 (1997). The connection of liquidity to accuracy of prices (through more competitive informed trading) is presented in a mathematical model by Anat R. Admati \& Paul Pfleiderer, A Theory of Intraday Patterns: Volume and Price Variability, 1 REv. FIN. STUDIES 3, 30-31 (1988).

288. See Robert A. Levy, The Prudent Investor Rule: Theories and Evidence, 1 GEO. MASON L. REv. 1, 7 (1994).

289. See William W. Bratton \& Joseph A. McCahery, Comparative Corporate Governance and the Theory of the Firm: The Case Against Global Cross Reference, 38 Colum. J. TRANSNAT'L L. 213,224 (2000).

290. Over half of the fifty stocks in the New York Times index were railroads. See, e.g., Joseph C. Mullin \& Wallace P. Mullin, United States Steel's Acquisition of the Great Northern Ore Properties: Vertical Foreclosure or Efficient Contractual Governance?, 13 J.L. ECON. \& ORG. 74, 92 (1997). 
with that available in today's market. As a result the investor would have to spread risk outside the market, with other ventures.

As the stock market produces the capacity for diversification, it attracts additional funds. These additional funds are primarily the information-less trading that is motivated by the life-cycle reasons of passive investors: savings during the investors' years of high income are stowed in the market by purchases of stocks and, later, sales produce retirement income or other compensation. The more investors are attracted to the market and the greater a portion of their available funds they put in the market, the more trading activity they create. The very fact that the investors are motivated by saving and consumption shows that their trading is not driven by information. Life-cycle trading is the very opposite of information-driven trading. The perfect example is the automatic trading that is triggered by the accrual of retirement benefits while employees work. A fraction of each paycheck goes into the employees' retirement account with no decision by the employee that the market is undervalued and ripe for purchasing. Even more emphatically uninformed are selling decisions. The retiring employees sell to obtain cash for consumption, not because they consider the market or any specific security overvalued. Furthermore, as the safety of the market increases due to diversification and as the market attracts greater shares of investors' investable wealth, more trading can occur accidentally due to unforeseen events that may deviate from the cycle of buying to save and selling to consume. Such accidents may be personal bankruptcies or family emergencies that put an immediate demand for funds on the investor. Those accidents force liquidations of stocks, liquidations that are obviously not motivated by the overvaluation of the stocks.

The danger of uninformed trading is that it may lead to uninformed prices. ${ }^{291}$ The increased information-less trading activity, however, comes with a built-in self-correcting mechanism. The danger for the accuracy of prices stems from the very fact that employees effectively buy stock blindly when they receive every paycheck (a fraction of which goes into their retirement account) and sell blindly when they need cash. This blind trading implies the possibility that overpriced stocks are being bought or that underpriced stocks are being sold, aggravating the price inaccuracies.

The self-correcting mechanism is based on the fact that the increased trading activity is an attractive environment for rational

291. See Georgakopoulos, The Tortured Transition, supra note 287, at 698 . 
speculators, traders whose activity is motivated by information..$^{292}$ Rational speculators (also called "informed traders") are the antithesis of the life-cycle investors. Contrary to life-cycle investors who devote infinitesimal time to the management of their investment, ${ }^{293}$ for the rational speculator trading is a main occupation. Contrary to the information-less trades of life-cycle investors, the trades of rational speculators are the response to a belief that prices are low or high, to the identification of a profitable opportunity for the trader.

The increased trading activity due to more life-cycle trading is attractive to rational speculators because it implies that they are able to take advantage of false prices now and that they will be able to trade again in the future to take their profits. The increased trading activity of the life-cycle investors does not only result in greater present liquiditythat is, greater ability to enter into trades-but also confidence in greater future liquidity. ${ }^{294}$ Upon identifying an undervalued stock, rational speculators are able to buy it because of life-cycle selling. A market consisting of only rational speculators would imply that nobody would be willing to sell the undervalued stock. ${ }^{295}$ Moreover, in a market with life-cycle trading, the speculators who buy the undervalued stock are assured that they will be able to sell it because they are confident in the existence of life-cycle buying in the future. Thus, the increased trading activity of the life-cycle investors is attractive to informed traders.

The confidence in life-cycle trading translates into more active trading by rational speculators. This additional informed trading implies greater price accuracy, since it means more buying at low prices and

292. See Sanford Grossman, On the Efficiency of Competitive Stock Markets Where Trades Have Diverse Information, 31 J. FIN. 573, 573 (1976).

293. See James A. Fanto, Regulatory Implication of Individual Management of Pension Fund: Comparative Investor Education, 64 BROOK. L. REV. 1083, 1096 (1998) (defining a life-cycle approach to investing as when an investor "adjust[s] the allocation of kinds of securities in his or her portfolio over the different stages of the life cycle").

294. See Georgakopoulos, The Tortured Transition, supra note 287, at 725.

295. Before this interaction of informed (rational speculators) and uninformed (life-cycle) trading was identified, this idea that trading is self-contradictory was puzzling and led to a line in the literature discussing the efficiency paradox: how come there is trading even when prices are accurate? The answer that was being overlooked was that there is trading because of uninformed life-cycle traders. The greater paradox is how come that strain of literature did not realize that in a world populated exclusively by rational speculators, all trading is a paradox: if prices are too high there would be no buying and if prices are too low, no selling. For examples from the "efficiency paradox" literature, see generally Grossman, supra note 292 (using hypotheticals to show the efficiency paradox); Paul Pfleiderer, Private Information Price Variability and Trading Volume 11 (1982) (unpublished Ph.D. dissertation, Yale University) (uninformed trading solves the efficiency paradox); see also Ronald J. Gilson \& Reinier H. Kraakman, The Mechanisms of Market Efficiency, 70 VA. L. REV. 549, 622-26 (1984). 
more selling at high prices. Prices are corrected faster and deviations from accurate valuation are smaller. While accurate valuation is desirable because it contributes to the optimal allocation of resources to firms, it also implies a safer ride for the life-cycle traders. Accurate pricing contributes to the optimal allocation of capital because it means that firms with bright prospects are able to sell shares at appropriately higher prices than firms with dim prospects. Thus, the market finances bright prospects without wasting funds on the dim prospects. But accurate pricing also provides a safer ride for life-cycle investors because it results in smaller deviations of prices from their appropriate level. This is nothing less than a safety increase that attracts more capital, feeding into the chain reaction of further improvements in market quality: more trading, greater liquidity, and more accurate prices.

\section{Semi-Entrenched Control as a Facilitator of Dispersed Ownership}

Let us turn to the response of founders of firms and of managers to the prospect of having no defenses against hostile takeovers. The owners and managers, who want to maintain control, will retain the majority of the corporation's shares. This would produce an investment universe wholly different from that existing in most common law jurisdictions that are characterized by strong investor protections. ${ }^{296}$ Majority ownership is the norm in civil law jurisdictions where a formalist legal tradition suggests that novel defensive tactics will not be upheld by courts. $^{297}$

296. See Rafael La Porta et al., Corporate Ownership Around the World, 54 J. Fin. 471, 511 (1999); Rafael La Porta et al., Legal Determinants of External Finance, 52 J. FIN. 1131, 1132 (1997) [hereinafter La Porta et al., Legal Determinants].

297. See La Porta et al., Legal Determinants, supra note 296, at 1137 . One might counter that it is not reasonable to think that the original founders of large European firms more than a century ago feared the development of hostile takeovers and the lack of defenses. Even a century ago, however, the formalism of the civil law system was apparent. Founders knew that civil law would be less responsive to new problems than a system where judges would be expected to evolve the law. Thus, we can easily see that owners face a higher risk with respect to unanticipated developments in civil law. The same developments would be addressed less abruptly by the more fluid and changeable common law system. One way for owner-managers to address the increased risk to which civil law exposes them is to maintain majority control and to diversify their exposure to the idiosyncratic risk of their firm by internal diversification. Along these lines I argue for the superiority of common law. See Nicholas L. Georgakopoulos, Predictability and Legal Evolution, 17 INT'L REV. L \& ECON. 475 passim (1997). The nearly constant updating of the common law and the periodic updating of civil law, produces law that is equally outdated on average. Nevertheless, if risk-aversion is taken into account, individuals prefer the small frequent changes of the common law to the occasional large changes of civil law. Since individuals do not know if they gain or lose by future legal changes, they consider them gambles and frequent small ones are preferred to few large ones. 
Moreover, evidence indicates that in the legal-economic systems that produce large private benefits of control (or, conversely, large minority discounts) privately controlled firms strategically preserve their control status. For example, Holmén and Högfeldt report that privately controlled Swedish firms are more likely than others to use low-voting shares to make acquisitions, and experience deeper discounts of their minority shares if members of the founding family other than the founder are in control. ${ }^{298}$ This evidence verifies that concentrated ownership produces wasteful nepotism, and that concentrated ownership perpetuates itself through the structure of corporate transactions. ${ }^{299}$ Not only do firms of concentrated ownership avoid dispersing the owners' control at the time they go public, but they also preserve the lock on control despite growth through corporate combinations. ${ }^{300}$

What are the ramifications of majority-owned firms, however? What are the grounds for the intuition that dispersed control is superior? Of the multitude of arguments, several are worth mentioning. The reduced float of public shares may well prevent the development of a liquid market, and, therefore, of an efficient market. ${ }^{301}$ Investors, without enough common stock to go around, will have trouble creating diversified portfolios. Firms will lose the financing capacity that a dynamic stock market offers, and will be forced to rely more on debt financing and internal financing. Both these effects create a bias against dynamic upstart firms: they will not be able to access financing since their risk precludes debt financing, ${ }^{302}$ and new ventures will tend to be

298. See HOLMÉN \& HöGFELDT, supra note 34, at 11, 19, 21. For similar evidence in the United States, see generally Morck et al., supra note 156 (studying the valuation of Fortune 500 corporations and finding a discount for family run firms).

299. See HOLMÉN \& HÖGFELDT, supra note 34, at 5, 32.

300. See id. at 32 .

301. See supra note 287 and accompanying text (discussing how liquidity (i.e., trading activity) leads to efficiency (i.e., accurate pricing)).

302. A simple example shows how the same risk that venture capitalists routinely finance would lead to crippling interest rates if debt financing were used. Suppose financiers expect to obtain a $10 \%$ return on their capital. If two of every three companies fail, the repayment of the third and successful one must compensate for the losses of the other two as well as provide the $10 \%$ return on the entire capital that was wagered in these companies. Consider that $\$ 33.33$ is lent to each of the three companies and that financiers recover nothing from failed firms. Since $\$ 100$ was lent, if the repayment period is one year, the single successful firm of the three would have an obligation to pay $\$ 110$, which implies an interest rate of $333.33 \%$ on its $\$ 33.33$ loan.

To make a more realistic guess, even if very rough, we have to make venture capitalists require a $30 \%$ return, give the companies they back a failure rate of $90 \%$ and use their 4.5 -year horizon, average. In 4.5 years at $30 \%$, a $\$ 100$ capital investment would need to become $\$ 100 *(1+.3)^{45}=\$ 325.65$, and since that must be produced by $10 \%$ of the backed corporations, the equivalent lending interest rate would have to grow $\$ 10$ into $\$ 325.65$ in 4.5 years, so it must be $116.9 \%$. This is still an underestimation because venture capitalists have a stake in their firms' 
started as in-house projects under all the stifling bureaucracy of large firms. This may also produce some social stagnation: reduced upward mobility by virtue of the reduced returns to young entrepreneurs. One must not overlook the crucially important aspect of peaceful changes of control, which are only possible if the unsuccessful controller fears being ousted in a proxy fight, i.e., only if there is no lock on control. Although related, we must not forget the tendency toward nepotism that family control produces. Finally, managers that own a controlling share of the corporation will not be perfectly diversified, which suggests that they would tend to run the firm in a risk-averse fashion, shying away from risk and the socially optimal stance of risk-neutral decisionmaking.

In sum, an environment of majority-controlled firms is likely to undermine many of the contributions of capital markets to productivity. Indeed, what the above shows is that many of these contributions are the result not of the existence of capital markets, but of dispersed ownership. Contrary to an ex ante incentive to maintain majority control that the lack of defenses creates, defensive tactics allow the controller to relinquish control. As long as the firm is run well, the controller faces little risk of being ousted. Perhaps with the help of some cognitive biases in favor of overconfidence, ${ }^{303}$ the results for society are the numerous advantages that flow from dispersed ownership.

\section{Semi-Entrenched Control as a Facilitator of Venture Capital}

In addition to all its other benefits, semi-entrenched control is a crucial component of the venture capital relationship. The venture capital relationship is much more complex than the explicit rights that the entrepreneur and the financier (venture capitalist) agree upon. One of the most important components of the venture capital relationship is the control of the start-up firm. The capital infusion by the venture capitalist allows the firm's attempt at success. Typically, the entrepreneur is allowed to run the firm while control rests in the financier's hands, but

further success by means of their equity investment. A lender charging $116.9 \%$ would have returns smaller than those of venture capital investors.

303. Two classic documentations of overconfidence, rating oneself as more intelligent and skilled than average, and considering oneself an above average driver, are 2 RUTH C. WYLIE ET AL., The Self-ConCEPT (1979), and O. Svenson, Are We All Less Risky and More Skillful Than Our Fellow Drivers?, 47 ACTA PSYCHOLOGICA 143 (1981). For a recent discussion of the this literature that is alternatively called behavioral decision theory, bounded rationality, or cognitive biases literature, see Russell B. Korobkin \& Thomas S. Ulen, Law and Behavioral Science: Removing the Rationality Assumption from Law and Economics, 88 CAL. L. REv. 1051, 1075-76 (2000). 
only as long as the venture goes well. ${ }^{304}$ If the firm falters, the financier may exercise control to minimize losses. ${ }^{305}$ If the firm succeeds, however, the control arrangement changes. The financier will exit by selling the controlling stake to the public in the successful firm's initial public offering. ${ }^{306}$ At that point, the financier stops being the largest shareholder. After the offering, the entrepreneur's stake is the largest, and the entrepreneur is able to exercise working control with $20 \%$ to $40 \%$ of the firm. The entrepreneur's payoff from the successful venture is not only the new stock wealth, but also, and with perhaps greater importance, the control of the firm. This environment reveals that the legal aspects of control can influence the arrangement in two ways. Control may be too ephemeral for the venture capital arrangement to be attractive to entrepreneurs, or minority shares may command too large a discount for the entrepreneur to credibly believe the venture capitalists' commitment to sell in the case of success.

The permanence of the control that the entrepreneur receives with the IPO, depends on defensive tactics. If the entrepreneur foresees ephemeral control because the legal system affords corporations no defenses, then the attractiveness of the venture capital arrangement is reduced. The magnitude of this effect cannot be measured. Nevertheless, the creative drive of startups that venture capital produces is so important for economic productivity, that even a marginal change in the attractiveness of venture capital may have huge implications for social welfare. ${ }^{307}$ It is also apparent from the Silicon Valley community that the productive drive of venture capital is contagious. ${ }^{308}$ Thus, if control is too ephemeral, the venture capital arrangement is not as attractive to the entrepreneur. This shortfall cannot be overcome by the financiers' compensating the entrepreneurs, because the reduced value of control is not a question of how the returns from the enterprise are divided, but one about the total production of the venture. If control is not valuable enough, fewer ventures will be attractive. A simple hypothetical illustrates this point. Consider two ventures that would produce the same

304. See Berglöf, supra note 36 , at 248 .

305. See id.

306. See Nicholas L. Georgakopoulos, Meinhard v. Salmon and the Economics of Honor, 1999 COLUM. Bus. L. REV. 137, 139 n.5.

307. See, e.g., James M. Dorsey, Management: This Venture Capitalist Still Believes in Startups, COMPUTING, Mar. 8, 2001, at 52, 52 (describing Dutch venture capitalist Roel Pieper's goal of proving "that the startup isn't dead and that there's good technology waiting to be discovered in Europe").

308. See Dante Chinni, The Man to See, WASH. Post, June 11, 2000 (Magazine), at 6, 8 (discussing Washington, D.C. area venture capitalist Steve Walker). 
monetary returns, but only one of them offered semi-entrenched control in case of success. If entrepreneurs found only that one were acceptable, while venture capitalists considered both borderline acceptable, only the one that provided semi-entrenched control would be pursued. ${ }^{309}$ This shows that semi-entrenched control increases the total expected value of the venture for the parties rather than simply reallocating value between them.

The legal conditions that lead to dispersed ownership also contribute to the credibility of the venture capital arrangement. The credibility at issue is that financiers will indeed sell their controlling stakes in successful ventures. ${ }^{310}$ In a legal system that adequately protects minority shareholders so as to foster dispersed ownership, ${ }^{311}$ the discount of minority shares from controlling shares is smaller than in systems where minority shareholders are not as well-protected. ${ }^{312}$ The larger the discount of minority shares, the larger the reduction in value of the financiers' stakes when their stakes are sold to the public. Thus, poor protection of minorities translates into greater discounts at the time of the IPO for financiers. Financiers can avoid the discount by leaving the controlling stake intact and either holding it or selling it to a buyer of control. In either case, however, the entrepreneur never receives control. Poor minority protection undermines the ability of venture capitalists to commit to disperse their controlling stakes in successful ventures. Since this commitment is of value to the entrepreneurs, the venture capital arrangement loses its appeal. Thus, the minority protection necessary for dispersed ownership is also necessary for the formation of venture capital. The importance of venture capital cannot be overstated. Apple Computer, Cisco Systems, Dell, and Gateway are all venture capital successes and the competitiveness these firms infuse into their industries disciplines every member of that industry. The capitalization of these

309. Of course, defenses influence the price at which the company would go public and would alter the returns to the financier. I argue below, however, that the semi-entrenched control would also be preferable from the financier's perspective. See infra notes 337-63 and accompanying text.

310. See Berglöf, supra note 36, at 247.

311. See John C. Coffee et al., The Direction of Corporate Law: The Scholars' Perspective, 25 DEL. J. CORP. L. 79, 98 (2000) (stating that "dispersed share ownership can only arise and persist under highly developed legal systems that give strong legal protections to minority shareholders").

312. See Blitch v. Peoples Bank, 540 S.E.2d 667, 669 (Ga. Ct. App. 2000) (indicating "that using discounts injects speculation into the appraisal process, fails to give minority shareholders the full proportionate value of their stock, encourages corporations to squeeze out minority shareholders, and penalizes the minority for taking advantage of the protection afforded by dissenters' rights statutes"). 
few venture capital successes, $\$ 610$ billion, $^{313}$ is woefully inadequate to describe the contribution of venture capital to the economy of the United States and the world.

In sum, in the above paragraphs I argued that dispersed ownership with semi-entrenched control is (1) instrumental in the creation of diversified investor portfolios that reduce risk, increase the attractiveness of the capital market and, thus, reduce the cost of firms' capital; (2) fundamental for the productivity of social resources by imposing risk-neutral management; (3) necessary for large publicly traded stakes (floats), which by virtue of the investor participation that diversification allowed, lead to frequent trading, and liquid markets. Liquid markets attract informed trader competition creating accurate prices, reducing the risk of market investments for investors. The increased attractiveness of the market further reduces firms' cost of capital. I also argued that semientrenched control is instrumental (4) for the incentives of founders to disperse their controlling stakes so as to create dispersed ownership, and (5) for the operation of venture capital. Ephemeral control would reduce the value of the enterprise to the entrepreneur. Furthermore, lack of minority protection, which is necessary for dispersed ownership, would cancel the credibility of venture capitalists' implicit promise to disperse their controlling stake in cases of successful ventures. In the next section I argue that defenses also provide help in the firm's relation with its managers, which again is crucial for the reduction of firms' costs.

\section{B. Defenses Provide a Superior Management Contract}

Corporate law academics have divided takeovers into efficient and inefficient ones. ${ }^{314}$ Strategic mergers are efficient because they create value through synergies and other productivity gains; ${ }^{315}$ acquisitions motivated by financial gains are inefficient because they are not directly

313. Apple Computer's capitalization is $\$ 20.1$ billion, CISCO Systems' is $\$ 465.3$ billion, Dell's $\$ 104$ billion, and Gateway's $\$ 20.9$ billion, which add up to $\$ 610.3$ billion. I have made data from Market Guide / Provestor for Apple, CISCO, Dell, and Gateway as of September 8, 2000 available on-line at http://www.iulaw.indy.indiana.edu/instructors/georgakopoulos/prof (last visited Oct. 17, 2000).

314. See John C. Coffee, Jr., Transfers of Control and the Quest for Efficiency: Can Delaware Law Encourage Efficient Transactions While Chilling Inefficient Ones?, 21 DEL. J. CORP. L. 359, 363 (1996).

315. See Miriam P. Hechler, Towards a More Balanced Treatment of Bidder and Target Shareholders, 1997 Colum. Bus. L. REV. 319, 394; Garry W. Jenkins, The Powerful Possibilities of Nonprofit Mergers: Supporting Strategic Consolidation Through Law and Public Policy, 74 S. CAL. L. REv. 1089, 1091 (2001). 
associated with increased productivity. ${ }^{316}$ Academic analysis has long attempted to prod corporate law in directions that would stifle financial deals without discouraging strategic ones. ${ }^{317}$ But little harm from financial deals has been proposed to counter the gain in productivity that strategic deals create. Granted, financial deals entail transaction costs that are wasteful from a social standpoint, but they have the redeeming virtue of aligning securities' prices. ${ }^{318}$ Thus, the balancing of these arguments could not favor defenses. What this balancing ignores, however, is the effect of undefendable financial deals on managerial incentives. The potential for low takeover prices means that the control of management is at the whim of the market and its occasional errors. Instead of management enjoying a degree of safety determined by their performance, management's control is exposed to the vagaries of the market.

This argument for the importance of defenses to dispersed ownership takes two steps. First, the stock market occasionally produces low prices. Due to uncertainty or error, the path that stock prices follow does pass from points low enough to make financial acquisitions worthwhile, jeopardizing the position of capable management. The next step is to realize the difference between being the Chief Executive Officer ("CEO") of a public corporation of dispersed ownership and a CEO subject to a majority controller. Also interesting are the associated dynamics on the senior management team. Members of the management team cannot be disloyal to the CEO with the hope of protection from the controller. The mere existence of a controller undermines the authority of the CEO.

1. Low Prices: True and False Indications of Managerial Performance

The evidence of the existence or occasional occurrence of errors in stock prices is overwhelming. From deep discounts of closed-end funds, ${ }^{319}$ to the ability of managers to time the offering of securities to

316. See Bebchuk, supra note 257, at 959 .

317. See Coffee, supra note 314, at 364.

318. See id. at 396-401.

319. See J. Bradford De Long \& Andrei Shleifer, Closed-End Fund Discounts, $18 \mathrm{~J}$. PORTFOLIO MGMT. 46, 46 (1992) (arguing that the size of the discount is an index of investor sentiment); Charles M.C. Lee et al., Investor Sentiment and the Closed-End Fund Puzzle, 46 J. FIN. 75,82 (1991) (indicating that the discounts are driven by investor sentiment). More recent studies of the closed-end fund discount puzzle include: Elroy Dimson \& Carolina Minio-Kozerski, ClosedEnd Funds: A Survey, 8 FIN. MARKETs, INSTITUTIONS \& INSTRUMENTS 1 (1999) (literature review), and Richard W. Sias et al., Can Noise Traders Survive? Evidence from Closed-End Funds, 1 ISE 
coincide with market highs, ${ }^{320}$ to the excessive fluctuation of stock prices, ${ }^{321}$ there is little doubt that stock prices can be inaccurate. Inaccurate stock prices undermine the premise of the market for control. While stock prices that are accurately low due to poor management trigger desirable takeovers, prices that are falsely low trigger pointless takeovers.

Furthermore, stock prices can be low enough for profitable financial deals because of uncertainty about future corporate choices rather than due to any inaccuracy. If a corporation can take one of several actions, each one of which produces different value for the shareholders, that potential should be reflected in the price. A simple example illustrates.

Suppose a corporation's choice involves developing a product independently or with a partner. Independent development would be a higher risk-reward proposition that would be favored by the risk-neutral dispersed shareholders. ${ }^{322}$ If successful, it would produce value of $\$ 15$ per share, and if unsuccessful, a value of $\$ 5$, for an average of $\$ 10$ if success is a 50-50 proposition. Shared development would reduce both the risk and the return that the firm would receive. If successful, it would produce a per share value of $\$ 12$, and if unsuccessful a value of $\$ 6$, for an expected value of $\$ 9$. Suppose that the circumstances make this choice imminent: the potential partner has made a take-it-or-leave-it offer to the firm. Although shareholders know what they prefer the corporation to do, there is genuine uncertainty regarding what choice

REV. 37, 70 (1997) (testing and rejecting the proposition that, because irrational "noise" traders receive compensation for carrying the excessive risk by the risk premium, they survive despite taking excessive risks).

320. See Jay R. Ritter, The Long-Run Performance of Initial Public Offerings, 46 J. FiN. 3, 23 (1991) (indicating that IPOs perform poorly because, among others, they are timed to coincide with market highs); see also Tim Loughran \& Jay R. Ritter, The New Issues Puzzle, 50 J. FIN. 23, 47 (1995). This is not a newly noticed phenomenon. See Roger G. Ibbotson \& Jeffrey F. Jaffe, "Hot Issue" Markets, 30 J. FIN. 1027, 1037-40 (1975).

321. See Robert J. Shiller, Market Volatility 131-48 (1989); John Y. Campbell \& Robert J. Shiller, The Dividend-Price Ratio and Expectations of Future Dividends and Discount Factors, I REV. FIN. STUD. 195, 220 (1988) (arguing that stock markets are more volatile than justified by subsequent changes in dividends); Sanford J. Grossman \& Robert J. Shiller, The Determinants of the Variability of Stock Market Prices, 71 AM. ECON. REV. 222, 222 (1981).

322. The shareholders of corporations with dispersed ownership are likely to be diversified. Diversification reduces or eliminates idiosyncratic risk, the risk that any one firm in their portfolio will have unusually good or bad luck. Instead, diversified shareholders care about overall performance. If the managers of all the firms in their portfolio tried to avoid risk by giving up some returns, the shareholders would enjoy a return that would be on average lower. If, by contrast, managers in each company take the risk-neutral choice of maximizing expected value, even if some of the investors' firms are unlucky, the lucky firms' gains will more than compensate investors. See supra notes 282-86 and accompanying text. 
growth by appointing an able permanent CEO. The market had a plausible fear. The potential existed for Thomas Lee to abandon the upside on its equity investment and ensure no further erosion of the value of the Conseco convertible preferred stock that they held. When eventually the new CEO was appointed, that uncertainty was resolved. The choice was Gary Wendt, a long-time head of GE Capital which under his stewardship had grown into the most profitable business of GE. ${ }^{328}$ Moreover, Gary Wendt's contract conveyed a multitude of signals that he would serve shareholder rather than bondholder interests. He had a five-year contract as opposed to a shorter term that might signal a winding down of corporate affairs. ${ }^{329}$ He would receive no salary for the first two years. ${ }^{330} \mathrm{He}$ would instead receive options, which only have value to the extent that he would cause the stock price to rise. ${ }^{331}$ His incentive bonuses were stock price targets, rather than bond prices or liquidation proceeds. ${ }^{332} \mathrm{~A}$ week after his appointment, Conseco's stock was at $\$ 11$, and by January 2001 , had again exceeded $\$ 18 .^{333}$

Without defenses, a takeover of Conseco for a significant premium over its Spring 2000 trading range of $\$ 5$ to $\$ 6$ was possible and was rumored. ${ }^{334}$ Would that be optimal for its shareholders or the economy? The acquirer would pursue growth as opposed to liquidation. Despite the doubts whether Thomas Lee would make the choice for growth that was

328. See Debra Sparks \& Pamela Moore, Rescuing Conseco, Bus. WK., July 10, 2000, at 54.

329. See Winners and Losers, WORTH MAG., Oct. 2000, available at http://www.worth.com/content_print/ZZZBXE8K6DC.html (last visited Sept. 24, 2001).

330. See id.

331. See id.

332. See id. For more details on Gary Wendt's compensation package, see Floyd Norris, Conseco Chief Got Big Bonus for Signing On, N.Y. TIMES, July 11, 2000, at C1. This $\$ 45$ million payment to Wendt, however, was claimed to be the assumption by Conseco of GE's obligations to Wendt, in consideration for the release of Wendt from his noncompete agreement with GE. See Joseph T. Hailinan, For Wendt, Conseco Post Cost $\$ 20$ Million, WALL ST. J., July 12, 2000, at C16.

333. See Company Research, Conseco, Inc., N.Y. TIMES, July 3, 2000, at http://marketwatch.nytimes.com/custom/nyt-com/html-historicalquote.asp?symb=CNC\&cl (last visited July 3, 2000); Company Research, Conseco, Inc., N.Y. TIMES, Jan. 29, 2001, at http://marketwatch.nytimes.com/custom/nyt-com/html-historicalquote.asp?symb=CNC\&cl (last visited Jan. 29, 2001).

334. See Investor May Make $\$ 3.3 B$ Conseco Bid, InDIANAPOLIs Bus. J., June 5-11, 2000, at 5 (discussing rumor of a $\$ 10$-per-share bid by financier Irvin Jacobs for Conseco). Note, however, that since Conseco was incorporated in Indiana, the voting power of an acquirer's shares is contingent on the affirmative vote of the majority of outstanding shares, see IND. CODE. ANN. \$ 23-1-42-9 (West 1989), and, if an acquirer of a majority does receive voting power, minority shareholders have the right to have their shares bought out for not less than the highest price the acquirer paid. See IND. CODE. ANN. \$ 23-1-42-11(a)-(b) (West 1989). These very strict obligations on an acquirer reduced the potential of Conseco as a target of a hostile tender offer, but they clearly did not eliminate the possibility of a hostile takeover. 
management will make. The extensive literature on agency costs suggests that this setting allows for a deviation of the interests of the managers (who are the agents) from those of the shareholders (who are their principals). ${ }^{323}$ The managers who do not reap the entire gain from making the correct decision may prefer to limit their downside, thus securing their jobs and the value of their talent in the market for "human capital." If the correct decision will be made, the stock should be valued at $\$ 10$. In anticipation of this decision, the stock price can justifiably fall below the $\$ 10$. Thus, a takeover could occur at any price below $\$ 10$. The acquirer would do nothing more than make sure the management team chose the value-maximizing alternative of independent development.

Much more extreme choices may be presented. Consider the example of a barely solvent firm that has on its board of directors representatives from investment firms that own convertible debt or preferred stock of the firm. Will the board take the risks that maximize shareholder value, or will they file for bankruptcy, or otherwise opt not to jeopardize the value of the firm's senior securities? Such a situation may have existed during the winter and spring of 2000 at one of the largest insurance corporations in the United States, Conseco, Inc. ${ }^{324}$ The firm's stock had tumbled from over $\$ 50$ in 1998 to under $\$ 20$ at the beginning of $2000 .^{325}$ At that point, the Thomas $\mathrm{H}$. Lee Co. investment firm made an infusion of $\$ 500$ million of capital in the form of preferred stock that could be converted to a stake of about $7 \%$ in the company with a cost basis of $\$ 17$ and received a seat on the board. ${ }^{326} \mathrm{~A}$ few months later, in April of 2000, Conseco's price having dropped to under $\$ 6$, the previous CEO was temporarily replaced by the Thomas Lee representative on Conseco's board. ${ }^{327}$ The stock price did not recover, as it should if the market were to assume that the new CEO would pursue

323. See, e.g., Victor Brudney, Corporate Governance, Agency Costs, and the Rhetoric of Contract, 85 CoLUM. L. ReV. 1403, 1411-12 (1985).

324. Conseco's revenues of $\$ 8.4$ billion exceed the $\$ 7.5$ of John Hancock and the $\$ 6.8$ of Lincoln National. Larger domestic independent insurance companies are AEG with $\$ 28.5$ billion of revenue, MetLife with $\$ 32.1$ billion, and Manulife Financial, with $\$ 9.2$ billion. Credit Suisse may have larger eamings in the aggregate, but the part attributable to its insurance operations could not be disaggregated for the purpose of this ranking. See generally MARKET GUIDE/PRoVESTOR PLUS COMPANY REPORT, CONSECO, INC. (2001), available at http://www.iulaw.indy.indiana.edw/instructors/georgakopoulos/prof/CNCMarketGuide.pdf (last visited Oct. 19, 2001).

325. See id. at 2.

326. See Conseco Completes Sale of Convertible Preferred Stock to Thomas H. Lee Company, BUS. WIRE, Dec. 15, 1999, at http://www.businesswire.com (last visited Dec. 31, 2001); Bemard Condon, Thomas Lee to the Rescue, ForBES, Dec. 27, 1999, at 32.

327. See Christopher Carey, Top Conseco Execs Hilbert, Dick Resign, INDIANAPOLIS STAR, Apr. 29, 2000, at A1. 
implicit in the stock price, they did make that decision. Moreover, the friendly solution, Gary Wendt, appeared on the scene with as much credibility and as well-networked in the financial community as any acquirer. A hostile battle in early 2000 would have been devastating for the firm and its economic productivity. Instead of focusing its efforts on finding an effective new CEO, the interim management would have had to expend effort thwarting a takeover. Shareholders would have lost the upside that the best CEO choice would bring; the Thomas Lee firm, in particular, would have been forced by a hostile acquisition to sell part of its investment at a loss. The economy would have lost in that the acquirer would have needed to line up a CEO with less information than Thomas Lee had already accumulated, producing a greater potential for error. Moreover, to the extent that working for a privately controlled company is not as attractive as being the head of an independent corporation, as will be argued below, an acquirer would not have had access to the same talent that the independent Conseco had.

The circumstances surrounding Conseco during the winter and spring of 2000 illustrates a crucial lesson for corporate law. Stock prices can be temporarily low, either because of market errors or because of uncertainty regarding impending corporate choices. In both cases, defenses allow incumbent management to devote its undivided attention to the firm and its productivity. Takeover defenses that delay hostile bids prevent hostile suitors from initiating a takeover during a temporary low price because the bidder knows the temporary nature of the situation and the delay that defenses create. Thus, the management team of the target never has to initiate a defense since a threat will not materialize. The delay that defensive tactics give to incumbent management produce more than extra time for an auction. They prevent hostile fights at times of temporarily low prices and increase corporate productivity by insulating management from financial bids at such times.

Defenses allow the firm to devote its undivided attention to productivity at times when the price of its stock leaves it temporarily vulnerable to an acquisition. Often, this timing will have increased importance because it will coincide with a crisis at the firm. The existence of a crisis is very likely to correlate with the low price of the stock. It is at such times that management needs to focus most on running the business without the distraction of a control fight.

A persistently low stock price, by contrast, without the urgency of a temporary corporate crisis, suggests long-term mismanagement and allows a hostile takeover despite the delays that defensive tactics interpose. Again, the delay built into hostile threats by the available 
defensive tactics prevents wasteful takeovers. The example of Conseco provides an illustration.

Conseco was built out of a collection of insurance companies that were acquired in sequence. ${ }^{335}$ The market rewarded the acquiring firm, that eventually became Conseco, with a high valuation for its stock because of the synergies apparent between the companies that were being combined by means of this acquisition spree. The high valuation enabled the acquirer to use its stock as an exchange medium and facilitated the acquisitions. When the time came to integrate the acquired companies, the management team that was so adept at assembling this desirable mix of assets proved inept at consolidating the numerous companies and realizing the synergy gains. The stock price drifted for almost a year from its high of $\$ 58$ in the spring of 1998 to under $\$ 5$ in the early summer of $2000 .^{336}$ This was no temporary crisis. The financial markets were looking for implementation of a strategy they had expected. Every day that this implementation did not materialize, the confidence in Conseco's management eroded. Eventually, the previous $\mathrm{CEO}$ and $\mathrm{CFO}$ were displaced by internal forces, by virtue of the strong position of the Thomas Lee firm on the board and the strong institutional ownership that backed Thomas Lee. ${ }^{337}$

Should a hostile takeover take place at the very instant that Conseco's undervaluation appeared? Hindsight shows that the change of control that was necessary to preserve the productivity of Conseco did take place, despite the lack of a hostile takeover. The disruption of a takeover was not necessary to achieve the change of control because internal forces led to that change peacefully. The staying of the previous management in place would have signaled a different situation, one where the internal pressures were insufficient to displace the ineffective management. In such circumstances, a hostile takeover would be the last bastion of economic productivity, the only means to effectuate the change of control that would realize Conseco's productive capacity.

It should be obvious that the delay defensive tactics induce works in a similar way in both the cases of persistent mismanagement and

\footnotetext{
335. See Conseco, Inc., Conseco Company Acquisition History, at http://www.conseco.com/csp/about_conseco/ac_companyprofile_history_acquisitions.htm (last visited Sept. 24, 2001).

336. For the prices, see Norris, supra note 332.

337. Institutions owned about 70\% of Conseco's stock. See John Pletz, Standard Pushes On: But Wall Street Isn't Paying Attention, IndianAPOLIS BuS. J., May 24-30, 1999, at 17. The institutions' opposition to the old management team is reported in Michael Fritz, They'd Hang Conseco Execs from Green Tree: Institutional Investors Push for Ouster, Sale, INVESTMENT NEWS, Apr. 10, 2000, at 6 .
} 
temporarily low stock prices. Just as the delay allows the undistracted management of the corporation during the price break, it also grants the time for an internal change of control during the time of persistent mismanagement. The waste of a takeover will only be necessary if the powers of internal corporate governance cannot produce the change of control that is necessary.

It is worth noting that a hostile acquisition at a time of low prices may force shareholders to sell at a loss. Given the potential for false low prices or for rational low prices, a shareholder may reasonably assume that he will not sell at such a time. But undefendable hostile offers may well force him to sell at such a time and erode his total expected return. The investment of the Thomas Lee firm in Conseco is a typical example. Identifying a good investment and reaching an agreement with management for a friendly and large financing like the $\$ 500$ million convertible debt that Thomas Lee bought ${ }^{338}$ does not happen every day. If the hostile acquisition that Irvin Jacobs threatened was to occur, Thomas Lee's returns would have been disastrous. The ability to engineer a friendly turnaround, on the other hand, would allow Thomas Lee's firm to obtain all the hoped-for returns. A hostile takeover that would hurt Thomas Lee would hurt turnaround financing generally. Unfettered hostile takeovers would lead investors to require higher returns to compensate for the possibility of a hostile takeover that would freeze them out of their investment. In the example of Conseco, the timing would have been particularly egregious. The Thomas Lee firm, after all, managed to identify the time that the stock of Conseco hit bottom with only a five month error. ${ }^{339}$ This should be cause for celebration rather than fear of being frozen out by a hostile offer.

To summarize, the benefit of the delay that defensive tactics induce consists of giving the internal structures of corporate governance the latitude to function. When able management is not distracted at times of short-term crisis, when inept management is changed with no hostile fight at times of a long-term display of incompetence, the economy gains. The gains consist of increased productivity and faster turnarounds in the case where defenses protect able management. In the case of incompetent management where defenses allow management replacement without a takeover fight, the gains consist of the savings of the cost of the hostile takeover. By having increased the costs of hostile

338. See Sparks \& Moore, supra note 328 , at 54.

339. Thomas Lee bought the stock about five months before the price reached its lowest level. See supra notes 327,336 and accompanying text. 
changes, defensive tactics have induced change that comes by means of cooperation and negotiation among large investors and the firms.

If management needs to be changed, however, the question arises whether the dispersed ownership that defensive tactics protect is desirable. After all, one could argue that a majority controlled firm would be able to change managers the fastest. The next section will argue that majority control by an individual or a family does not necessarily lead to easy changes of control.

2. The Market is a Nice Boss to Have

One could counterargue that the fear outlined above is chimerical, and takeovers at times of low prices do not induce any loss of productivity. Despite no empirical support for such a proposition, the argument that acquisitions can be nonevents for senior management has credibility because it can take a very simple and persuasive form. If it is best for the firm to retain its exact current management, a self-interested acquirer will not upset the management structure. The fallacy of this argument lies in the idea that the top management of the target will consider the acquisition a nonevent. Being acquired, however, radically changes the circumstances in which top management performs its job. Instead of being accountable to the diffuse market, in essence to the analysts and speculators whose consensus is reflected in the stock's price, the acquisition brings a definite boss, a single entity to whom strategies must be justified and whose estimate of the future determines the safety of the jobs of senior management.

The difference is more than the psychological demotion of suddenly having a boss. When the CEO is accountable to the market, the loss of the confidence of a single analyst or shareholder means little. Effectively, the market consensus determines the price of the firm's stock. While the safety of the CEO's position does depend on the stock price, the sale of one shareholder's stake or the downgrading by one analyst will have a small effect on the stock price. Moreover, the able CEO will easily find a different analyst who does believe in the firm's strategy. Effectively, when the senior management's performance is evaluated by the market, the evaluation is collective. Management has a diversified portfolio, not of stocks, but of evaluators. The CEO who is evaluated by the market has a reduced risk. Idiosyncratic changes in evaluations by the different shareholders and analysts cancel out, reducing risk.

Thus, even if an acquirer desires to keep current management, top management is not likely willing to stay. Not only does staying involve 
loss of independence and authority, but it also consists of an increase of the risk under which senior management operates. Finally, the market for human capital may punish a CEO's decision to stay after an acquisition. If the acquisition implies a demotion because of the loss of authority and increase of risk, the fact that the CEO stays after being acquired is equivalent to accepting a demotion.

In sum, the corporate defenses that preserve dispersed ownership protect senior management not only from losing control without having shown incompetence, but also from sudden increases in their evaluation risk.

3. Assured Replacement of Ineffective Management

While dispersed ownership combined with Delaware-style defenses prevents accidental replacement of management, it also consists of a mechanism that ensures that ineffective management will get replaced. The argument that defenses allow incapable managers to retain control has often been made. Delaware's defenses, however, allow changes of control. ${ }^{340}$ Delaware's semi-entrenched control does not prevent changes of control. ${ }^{341}$ Incapable management of corporations under dispersed ownership can only remain entrenched under defense law that is stronger than Delaware's, such as Indiana's. ${ }^{342}$ However, even under Delaware law, a merger is delayed for three years. ${ }^{343}$ Since simple acquisitions of shares are unimpeded, we must compare their treatment to that of mergers. The likelier strategic motivation of mergers suggests they should be easier than acquisitions, which are more likely to be driven by speculation.

The popular Delaware-style defenses, however, do not afford incumbent management nearly as much time. The Delaware courts treat poison pills as a means to conduct an orderly sale of the firm, rather than a means to insulate management in perpetuity from acquisitions. ${ }^{34}$ Shark-repellent defenses in the voting machinery give management advance notice of the threat, and the few defenses that allow limited rescheduling of the shareholder meeting give management some lead time. ${ }^{345}$ With these defenses as a backdrop, incompetent managers cannot

340. See discussion supra Parts III.A \& III.B.

341. See discussion supra Part II.B.3.

342. See discussion supra Part II.B.2.

343. See Del. Code ANN. tit. 8, \$ 203 (Supp. 2000).

344. See, e.g., Moran v. Household Int'l, Inc., 500 A.2d 1346, 1350 (Del. 1985).

345. See Ronald J. Gilson, The Case Against Shark Repellent Amendments: Structural Limitations on the Enabling Concept, 34 STAN. L. REV. 775, 780-81 (1982). 
expect to retain control for long in the face of a hostile attack. The defenses that Delaware provides to corporate managers are surmountable when compared with those of other jurisdictions. The surmountable nature of Delaware defenses ensures that lack of skill will eventually cause the replacement of the management team. The ease with which control can change, however, does not depend only on defenses, but also on ownership dispersion.

At this point it is worth digressing to discuss terms in the managerial contract that may compensate for the reduced security of not having takeover protections. The paradigmatic term of this type is the golden parachute, the granting to the managers of a handsome severance package that is triggered by the change of control. This and other equivalent terms are crucially important for the analysis because by compensating the manager for the risk of a change of control, they can make the managers indifferent to a hostile takeover. Thus, the managers would consider equivalent employment in a corporation with defenses (semi entrenched control) and employment in a corporation without defenses but which offers a golden parachute (ephemeral control with compensation).

This equivalence suggests that since firms do not choose to substitute defenses with golden parachutes, defenses are superior from the shareholders' perspective. This conclusion would support the thesis of this Article because it would indicate that shareholders prefer management continuity over rash takeovers.

Golden parachutes would provide a bias to management, however, that may make them costly. By compensating managers for a change of control, golden parachutes insulate against a risk that has also the desirable effect of motivating management to avoid the market's discipline. Managers protected by golden parachutes have a reduced incentive to run the firm well because they can profit by their own failure. Thus, one could still argue that shareholders prefer fewer defenses but find the compensation that managers would require too costly.

The objection, however, does not trump the support for defenses that is drawn from their preference. Any compensation of managers for change of control would blunt the disciplining effect of the market for control. If managers fear false changes of control and defenses that produce semi-entrenched control counter this fear, defenses are superior to an insurance system that would blunt incentives. The preference for defenses compared to golden parachutes absolutely shows that semientrenched control is superior to ephemeral control. Semi-entrenched 
control is superior because it offers a more beneficial management contract and more beneficial performance incentives, which is what my arguments have been about all along.

\section{Solving the Collective Action Problem of Adapting to Technological Change}

The last major advantage of dispersed ownership and defenses may be one of the most important ones as well. Concentrated ownership implies reduced agency costs because managers are directly responsible to the controller for performance. Corporate defenses and dispersed ownership produce semi-entrenched management. Management does promote the interests of shareholders, but management is also more independent from shareholders than under concentrated ownership. This agency cost produces a paradoxical advantage that has its source in the change of technology and the retraining of the labor force.

Technological innovations can have a dramatic impact on the nature and methods of production in the industries where they occur. Technological change may often occur in a dispersed and haphazard fashion. Only one or a few industries may be influenced by the innovation. Other times, however, the technological change may be so sweeping that most industries change shape. Historical examples of sweeping technological change abound, starting with fire, the wheel, the development of agriculture, through the industrial revolution, electricity, mass or chain production, all the way up to computerization, networking, and the telecommunication revolution that is still unfolding.

$\mathrm{Be}$ it haphazard or sweeping, change means that the actual employees will be forced to change their ways or will be replaced by people with the new skills. Roughly speaking, hunters were forced by agriculture to become farmers, farmers were forced by the industrial revolution to become craftsmen and workers, craftsmen were turned to laborers by mass production, and clerical workers are changing into help desk employees by the technological revolution.

\section{The Difficulties of Retraining}

These are not easy changes for a society to make. If the workforce can survive the retraining, the economy can achieve a higher level of welfare. A successful transition, however, can be extraordinarily delicate. Fast retraining may require that workers abandon their productive work to focus on their retraining. An economy may not be able to afford to retrain all its workers at once because their removal 
from production eliminates the product that is necessary for their sustenance and retraining. If change is too sudden, it will produce a transition bottleneck, which may transmute into a real economic shock. A typical scenario of such a bottleneck would have firms and individuals estimate the cost of retraining before the massive increase in demand caused by the simultaneous adoption of the new technology. After making the capital investment for the new technology, firms cannot use the old skills, and employees cannot afford to acquire the new ones. The result would be massive destruction of productivity and wealth. ${ }^{346}$

The recent experience of the Soviet economies with their transition to capitalism is analogous. This sudden technological transition has destroyed a large part of Russian productivity. ${ }^{347}$ The contrast between the destruction of the Soviet economy and the relative success of the gradual reform of the Chinese economy is a case in point. ${ }^{348}$

\section{Management and Modernization}

Dispersed ownership and corporate defenses allow managers to resist modernization pressures, but only for a limited time. The result is

346. An attenuated version of such transitions is in RoDY MANUELLI, TECHNOLOGICAL Change, the LABor MARKeT AND THE StOck MARKET (Nat'l Bureau of Econ. Research, Working Paper No. W8022, 2000), which argues that during technological transitions, new firms attract capital and labor by offering high returns and wages, but the result is gradual adoption of new technology and transitional unemployment. See also WILLIAM J. BAUMOL \& EDWARD N. WolfF, PROTRACTEd Frictional UNEMPLOYMENT as a HEAVy COST OF TECHNICAL PROGResS 1-2 (Levi Econ. Inst., Working Paper No. 179, 1996) (indicating that the sunk-cost nature of retraining expenses leads to distributional effects, by which classes of workers do not train in the new technology, producing "protracted frictional unemployment"); MARTIN ZAGLER, AGGREGATE DEMAND, ECONOMIC GROWTH, AND UNEMPLOYMENT 9 (Working Paper, 2000) (indicating that at transitional times, new firms facing risky demand for new products are forced to offer risk premiums on their risky jobs, reducing technological implementation and producing transitional unemployment), available at http://papers.ssm.com (last visited Sept. 12, 2001). Very similar is the problem of transitional unemployment as an economy changes from state-directed to a market orientation. See Zuzana Brixiova \& Tarik Yousef, Labor Market Adjustment in Transition Economies with On-the-Job Search, 67 ECON. LETTERS 223 (2000) (deriving the optimal speed of closures of firms in the state sector as employees search for jobs); Edward X. Gu, From Permanent Employment to Massive Lay-Offs: The Political Economy of "Transitional Unemployment" in Urban China (1993-8), 28 ECON. \& SOC'Y 281, 281-82 (1999) (providing a case study of the Chinese transition, which produced massive unemployment); Halvor Mehlum, Why Gradualism?, 7 J. INT'L TRADE \& ECON. DEV, 279, 294 (1998) (arguing in favor of gradual rather than sudden removal of import tariffs to address transitional unemployment).

347. About half of the Soviet Union's economic activity had been lost by 1997. See Sherman Garnett, Russia's Illusory Ambitions, 76 FOREIGN AFF. 61, 61-62 (1997).

348. See, e.g., William H. OVERHolt, THE Rise Of ChINA: How ECONOMIC Reform IS CREATING A NEW SUPERPOWER 32-36 (1993); Susan Tiefenbrun, Piracy of Intellectual Property in China and the Former Soviet Union and its Effects Upon International Trade: A Comparison, 46 BUFF. L. REv. 1, 5-9 (1998) (providing further citations). 
that the technological shock hits industry in two stages. Firms under concentrated ownership first feel the incentive to change. ${ }^{349}$ In contrast, firms under dispersed ownership can resist, but only temporarily, the incentive to adopt the new technology. The gains from modernization are, of course, the same for both types of firms. The personal discomfort of laying off long-time workers is also the same. The increased agency costs of dispersed ownership induces managers to veer from the narrow path of immediate maximization of shareholder value. Corporate defenses allow them to resist even pressures to change that come from the threat of hostile acquisitions. As developed under Delaware law, however, the defensive measures will not operate in perpetuity. The inefficiencies will soon be large enough to overcome the collective action problems of dispersed shareholders and if management continues to not modernize, it will be replaced.

An example will illustrate how this agency cost that burdens shareholders becomes a paradoxical advantage for society. The society has one thousand workers, divided into one hundred firms, with ten workers at each firm. Workers produce value of $\$ 550$ per month using the old technology. Ten percent of the workers acquire the new skill and their productivity becomes $\$ 600$ per month. The rest must be retrained. First, consider that a society chooses to shift methods of production and to finance this expenditure from tax revenue. As soon as the new technology arises, all of the 900 old technology workers are let go. The government must support them and retrain them. Suppose that each worker requires $\$ 500$ per month to survive during the three months of retraining.

Compare this to a situation in which the 900 workers who are to be retrained do so gradually. They are retrained at the same cost on the job or after hours while maintaining their old jobs. The economy does not lose three months of productivity for each of the 900 workers and does not need to produce welfare expenses. However, the increased productivity will come at a later time, say in eight months instead of three. Thus, this society loses five months of increased productivity (five months times $\$ 50$ per worker times 900 workers is $\$ 225,000$ ) but saves

349. One might interject that the argument here seems to contradict the previous analysis that concentrated ownership cannot escape inefficient management by owners. No contradiction exists because not all firms with concentrated ownership are inefficient. The point of the argument here is that firms with concentrated ownership that is skilled will face the strongest time pressure to adopt the new technology, lay off their workers, and hire new ones that are adept in the new technology. Indeed, the previous argument implies that inefficient firms with concentrated ownership will fade away, so that at any time there will only be the average number of inefficient firms with concentrated ownership. 
three months of lost productivity (three months times $\$ 550$ per worker times 900 workers is $\$ 1,485,000$ ). Clearly, the society would elect gradual change. Individual firms, however, do not take into account the social problems of retraining so as to graduate their adoption of the new technology. If the new technology promises increased productivity they will adopt it and demand that their employees produce it. ${ }^{350}$

The operation of the markets may counter this push toward the false choice of immediate mass retraining. A wage differential might develop. Workers familiar with the new technology will command higher wages, perhaps, and that will lead firms to retain the old-technology employees. The computer revolution presents a different possible outcome. The new technology may be so pervasive that everyone has some exposure to it and employees cannot differentiate efficient from inefficient users of the new technology at hiring time. All employees obtain the same wage but competitive pressure pushes for productive use of the new technology. Left to the pressure of competition, firms may well press workers for immediate retraining. Hostile acquirers may be able to realize gains from immediate retraining if the target's management does not press for retraining. Defenses that protect firms from immediate takeovers allow management the otherwise wasteful luxury of resisting the pressure for immediate retraining.

Rules concerning severance pay may change the incentives of firms. Similarly, the conclusion may be different if the change in productivity is so great that the gains from switching earlier outweigh the costs of the abrupt change. In these cases, defenses may have no effect on the speed of adoption of the new technology.

The transition to a new technology is more than a problem of choosing the appropriate pace of retraining. The danger exists that a market with restraints will fail to address the problem of adapting to the new technology. Each firm needs to retrain its employees in order to reach the new greater productivity, but each firm fears that if it were to retrain its employees, the other firms will simply hire them away. The reluctance of firms to provide general skills is generally

350. This example assumes that a centralized welfare and retraining system would produce the same outcome as a retraining system governed by the market forces. To the extent that government is considered an inferior decision-maker, preventing the government-led plan will have additional advantages. If we suppose that elected officials would be biased in favor of employees' interests because they are more numerous, we would expect a governmental transition to be slower than that instituted by concentrated owners or by managers of dispersed firms who face the threat of the market for control. 
acknowledged. ${ }^{351}$ General skills are acquired at workers' own expense at specialized schools and universities. ${ }^{352}$ Firms are willing to provide firmspecific training. ${ }^{353}$ A broad new technology, such as computerization, depends on a general skill which firms are reluctant to provide.

Takeover defenses that preserve dispersed ownership do not solve the problem, but the graduated technological change that they induce prevents the complete breakdown of modernization incentives. Firms under concentrated ownership fear that if they retrain their employees, other firms will hire them away. ${ }^{34}$ The attenuated incentives to modernize that firms having dispersed ownership face mitigate this fear of being poached. Modernizing firms know that the opportunistic strategy of mass layoffs and replacements is slightly less likely to be adopted by dispersed-ownership firms because the agency cost of their management makes mass replacements less appealing. Moreover, the defensive capacity of firms with dispersed ownership means that they can resist acquirers who may be willing to adopt the opportunistic strategy after an acquisition.

\section{Market Attraction: Preserving Market Returns}

In addition to all the above desirable social consequences of takeover defenses, defenses have positive consequences for investors. However, these are often ignored because of the large premiums that hostile offers entail. This section argues that the large ex post premiums are not so large when viewed ex ante. Hostile offers have numerous negative tax and transaction cost consequences, which shows that investors do not lose nearly as much as it appears by defenses that delay hostile offers.

Hostile takeovers, when successful, force an exchange of investors' securities with cash-rarely with securities. ${ }^{355}$ This produces a strong impetus for a reinvestment trade on the part of the investor. This forced

351. See, e.g., Paul Ryan, The Costs of Job-Training for a Transferable Skill, 18 BRrT. J. INDUS. REL. 334, 345, 350 (1980). See generally Marino Regini, Firms and Institutions: The Demand for Skills and their Social Production in Europe, 1 EUR. J. INDUS. REL. 191 (1995) (exploring the alleged advantage in the provision of general training that the German system has because it prevents a nontraining employer from poaching the employees other employers train).

352. See, e.g., Ryan, supra note 351 , at 342.

353. See John A. Litwinski, Regulation of Labor Market Monopsony, 22 BERKELEY J. EMP. \& LAB. L. 49, 62 (2001).

354. See, e.g., Ryan, supra note 351 , at 337.

355. In all of the hostile takeovers studied in Part III, the consideration was always cash, except in Unocal. In Unocal, Mesa's second-tier was securities and after the decision in that case, such a strategy is avoided. See supra text accompanying notes 82-174. 
sale and the nearly forced purchase that follows it impose on the investor numerous negative consequences. Investors are made to face tax, transaction cost, and gambling disutility burdens at unanticipated times. Most of these costs simply reduce the returns that investors can expect from the stock market. This creates incentives to move capital away from the market into alternative investments, such as real estate or private business dealings, or channeling their investments through intermediaries such as insurance companies. Some of these incentives, such as that produced by the risk of double short-term-gain treatment (instead of the single long-term gain treatment investors expect after a long-term investment) distort investors' choice by having a more negative impact on investors with a shorter investment horizon.

\section{The Tax Burden of Unanticipated Takeovers}

Unanticipated hostile takeovers have two negative tax effects on investors. For long-term holders, periodic takeovers reduce the total return by accelerating the time at which the capital gains tax is paid. ${ }^{336}$ For shorter-term investors and traders, the tax effect of takeovers is to reduce the profit from identifying a trading opportunity (a mispriced stock). ${ }^{357}$ The two effects are best illustrated in examples.

\section{a. Reducing Returns for Long-Term Holders by Accelerating Tax Payment}

A typical example will illustrate the effect of takeovers on an investor who saves for retirement in ten years. Our investor faces the question whether to put $\$ 100$ in the stock market or in the bond market where some tax-free bonds and bond funds exist. The stock market offers an expected return of about $10 \%$, all of which is, for simplicity, in the form of capital gains. The investor is taxed, say, at an $18 \%$ rate on capital gains.

Putting $\$ 100$ in the stock market that performs $10 \%$ on average suggests that in ten years this will have grown to $\$ 100 *(1+.10)^{10}=$ $\$ 259.40$, for a gain of $\$ 159.40$ before taxes and $\$ 130.71$ after taxes. If in year five, takeovers occur at one-third of the firms in our investor's

356. The takeover act creates a realizing event, for the selling of stock can lead to gains, thus triggering tax consequences. See I.R.C. § 61(3) (West 2001). Of course, if the holding period requirement is met, these gains would be taxed at the long-term capital gains rate. See id. $\$ \S 1(\mathrm{~h})$, 1222-1223.

357. Short-term capital gains are defined as the gains from the sale or exchange of a capital asset held for less than one year. See id. $\$ 1222(1)$. These gains are taxed at regular income tax rates, rather than at the long-term capital gains rate. See id. $\$ 1(\mathrm{~h})$. 
portfolio, capital gains will have to be paid at that time. Thus, in the fifth year, after the portfolio has grown to $\$ 100 *(1+.1)^{5}=\$ 161.05$, the gain of one-third, i.e., $\$ 20.35$ of the $\$ 61.05$ total gain, will be taxed at, say, $18 \%$ and $\$ 3.66$ will be removed from the investor's portfolio for the tax payment. The remaining $\$ 157.39$ continues to grow at $10 \%$ for another five years. By then, the portfolio has grown to $\$ 157.39 *(1+.1)^{5}=\$ 253.48$, before taxes. Of this, a fraction corresponds to the reinvested proceeds of the firms that were taken over, so that the capital gains must be calculated using the increased basis. In the fifth year the investor received cash for a third of the $\$ 161.05$ portfolio, namely $\$ 53.68$, from which $\$ 3.66$ was paid as capital gains taxes, leaving $\$ 50.02$ for reinvestment. All told, the investor ends up with $\$ 228.86$ after taxes, ${ }^{358}$ which corresponds to an $8.63 \%$ annual return after taxes. By contrast, the same investment with no early taxation will leave our investor with $\$ 230.79$ after taxes, ${ }^{359}$ and an $8.72 \%$ annual return after taxes.

The difference from an annual after tax return of $8.72 \%$ to one of $8.63 \%$ is not staggering, but it would still persuade some investors to switch to alternative investments. Over the long time periods involved, the accelerating of tax payments has an effect that is compounded by the fact that the investor loses the benefit of being able to invest the taxed part of his capital.

The next tax effect of takeovers influences mostly traders rather than diversified investors. While no tears may be shed for the hardships of a trader's life, traders do provide the service of correcting false prices, a service that allows the capital allocating function of the securities markets to operate smoothly. ${ }^{360}$ The tax effect of takeovers makes traders refrain from correcting prices because it can dramatically reduce their profits, particularly because it may switch the trader from a long-term capital gain treatment to the higher tax rates of a short-term gain.

358. The $\$ 50.02$ continues to grow at $10 \%$ and five years later becomes $\$ 50.02 *(1+.1)^{5}=$ $\$ 80.56$. The gain these last five years was $\$ 80.56-\$ 50.02=\$ 30.54$, and payment of $18 \%$ of that leaves $\$ 75.06$ of original capital plus gains after the tax payment. The other two-thirds of the portfolio, namely $\$ 66.67$ of the original $\$ 100$, has grown without taxation for ten years, It has grown to $\$ 66.67 *(1+.1)^{10}=\$ 172.92$, producing $\$ 106.25$ of capital gains for taxation. After paying the $18 \%$ tax on these the investor is left with $\$ 153.80$ of original capital plus gains. Thus the $\$ 100$ investment has become after tax $\$ 153.80+\$ 75.06=\$ 228.86$.

359. The $\$ 100$ grows to $\$ 100 *(1+.1)^{20}=\$ 259.40$. The investor is left with gains of $(100 \%-18 \%) * 159.4$ after paying the taxes on this, or gains of $\$ 130.79$. Thus the $\$ 100$ investment has become after tax $\$ 230.79$.

360. See Georgakopoulos, Informed Traders, supra note 287, at 424. 
b. Reducing Profits From Identifying an Undervalued Stock

The incentives on investors can be restated by focusing on the margin of error investors require before buying and, thus, contributing to a correction of the false price. Without defenses, buyers may incur income treatment of their gains. With defenses, however, they are (almost) assured that they can wait past the cut-off between short-term gains, ${ }^{361}$ which are treated as regular income, ${ }^{362}$ and long-term capital gains, ${ }^{363}$ which are taxed at a lower rate ${ }^{364}$ Since the prospective after-tax gains are larger with defenses, they will buy at smaller discounts and contribute more to the accuracy of market prices.

A simple example shows how an investor who identifies an undervalued firm is influenced by the prospect of a hostile takeover that may force short-term gain tax treatment. Ms. Ina Vestor identifies a firm which trades at $90 \%$ of its value, its shares trading at $\$ 0.90$ instead of their true value of $\$ 1$. Ina estimates that in two years, a point in time comfortably past the cutoff point for her profits to be treated as shortterm gains, the market as a whole will on average be $20 \%$ higher. The undervaluation of the firm, which has average market risk, will have been corrected. Her $\$ 0.90$, in effect will become $\$ 1.20$. At an $18 \%$ tax treatment of long-term gains, she will net a profit of $\$ 0.246$ for every $\$ 0.90$ she invests, or a $27 \%$ return after tax.

This calculation changes, however, if Ina considers a hostile takeover a likely possibility. If a hostile takeover occurs, her shares will be bought from her at a tender offer, which will not allow for reorganization tax treatment that would prevent capital gain realization by shareholders. ${ }^{365}$ Suppose the takeover occurs a year after Ina buys, at $\$ 1.10$. Ina's short-term gains are taxed at, say, $39 \%$, and she nets after taxes $\$ 0.122$. Adding these to her capital of $\$ 0.90$, she will participate in the $10 \%$ additional return of the second year, but again, if she must sell, any gains would be taxed at the short-term rate. Were she able to earn another $\$ 0.90$, which is less likely after the tax bite has reduced what she can invest, she would still end up with $\$ 0.061$ after tax, for total gains of

361. See I.R.C. $\$ 1222(1)$.

362. See I.R.C. $\$ 1(\mathrm{~h})$.

363. See I.R.C. \& 1222(3).

364. See I.R.C. \&1(h).

365. Friendly corporate combinations that observe some formalities can be completed without triggering capital gains. The exchange of the shareholders' old securities for the new ones is not considered a trade but a continuing interest in the changed firm. See I.R.C. $\S 368$ (West 2000). Hostile acquisitions will typically not be able to comply with the terms of section 368 for reorganization treatment, and are realization events. 
$12.2+6.1=\$ 0.183$. All this assumes that she will not have to pay brokerage fees or any other commissions in order to reinvest her money. Instead of $27 \%$, Ina is looking at $20 \%$. But $20 \%$ is what she could do by investing in the market, staying with her diversified index fund, and incurring none the idiosyncratic risks of investing in a single firm. Hence, investors who, like Ina, consider a hostile takeover likely, will probably not correct the $10 \%$ error in the stock price. If, by contrast, investors know that financial buyouts offering no more than to correct market errors can be blocked by defensive tactics, then they know that their investment period will not be cut short by hostile offers devoid of synergy gains. The investment in the undervalued firm becomes once again attractive.

Ina Vestor can overcome the problem of short-term gain treatment by extending her investment horizon. A stock that she will hold for two years will produce two taxations of her gains as income. Unless the hostile takeover occurs in the beginning or the end of the two-year period, both the gains it produces as well as the gains of the stock with which it is replaced will be taxed at the income tax rate. Investors can avoid one of the two short-term gain treatments by only investing in the market if they have a long enough or a flexible enough investment horizon to wait out any hostile takeover. This, in turn, means that some short-horizon funds will not be placed in the stock market. In fear of being eroded by the tax and other ramifications of hostile takeovers, short-term funds (that with defenses would go into the market) will stay in deposit accounts. As with the removal of funds of any horizon, this implies a slight pressure upwards for firms' cost of capital. Short-term funds perform an additional role-the frequent trading they imply fuels the market's liquidity. Their removal casts the spell of reduced liquidity. Prices become more sensitive to trades, informed trading is discouraged, market efficiency is reduced, and investors become more hesitant to invest in the market. ${ }^{366}$

\section{The Transaction Costs of Unanticipated Takeovers}

Hostile takeovers also impose on investors the payment of a new bid-ask spread and a new brokerage commission and all the fees associated with a market trade. The investor's portfolio is balanced before the hostile takeover. The takeover replaces a portion of the portfolio with cash. If the investor does not want to reduce his

366. This spiraling effect of liquidity was explained above. See supra text accompanying notes $287-95$. 
investment, he must reinvest this money. Reinvestment implies the investor will bear the trading costs, which are the bid-ask spread and brokerage fees and commissions.

The bid-ask spread is the spacing between the prices at which other market participants stand ready to buy (what others bid for the stock) and sell (what others ask for the stock). ${ }^{367}$ Depending on the investor's trading strategy the investor will pay or receive some fraction of the bidask spread. "Market" orders (orders to trade at the current market price without any limit as to what that price is) ${ }^{368}$ effectively "pay" a large fraction of the spread. ${ }^{369}$ The alternative strategy to market orders is for investors to place "limit" orders, which are orders to trade at a specific price, too good for the current market conditions, too low if the investors are buying, too high if they are selling. ${ }^{370}$ As investors are more willing to risk having their order remain unfilled by placing a "limit" order, they increasingly avoid the burden of the bid-ask spread. They may even receive the spread if their order is met by a favorable "market" order. For example, suppose the spread is " $\$ 99$ bid by $\$ 100$ asked." An investor who places a limit order to buy at $\$ 99$ and whose order is filled because of a market order to sell, receives the benefit of the spread.

Although brokerage commissions are much lower than they have been and may have even disappeared for small market orders, they still exist for larger orders and all sizes of limit orders. ${ }^{371}$ Moreover, fullservice commissions are often paid by investors as compensation for using the research that the brokerage house provides. ${ }^{372}$ Thus, in addition to the bid-ask spread, investors who suddenly find their positions in a

367. See BLACK'S LAw DICTIONARY, supra note 5, at 154, 1411.

368. See id. at 1124.

369. See, e.g., Jeffrey M. Bucidore \& George Sofianos, Liquidity Provision and Specialist Trading in NYSE-Listed Non-U.S. Stocks, 63 J. FIN. ECON. 133 (2002) (stating that non-United States stocks have wider spreads because of higher information asymmetry; the greater spreads, paid by traders to the market-making specialists, compensate them for this greater risk); see also infra note 375 .

370. See BLACK's LAW DICTIONARY, supra note 5, at 1124.

371. American Express, for example, offered no-commission on-line trading in 1999 to customers with accounts of $\$ 25,000$ or more. See Robert Barker, This Mess Will Cost AMEX, BUS. WK., Oct. 30, 2000, at 144.

372. Regardless of how low the commission may be, market orders still pay the bid-ask spread. The low-commission trading is possible because some brokerage houses pay other brokers for directing these small market orders to them, and they essentially profit from the bid-ask spread. For a study of the payment for order flow, as this arrangement is called, see Marshall E. Blume \& Michael A. Goldstein, Quotes, Order Flow, and Price Discovery, 52 J. Fin. 221, 226-27 (1997). See also Allen Ferrell, A Proposal for Solving the "Payment for Order Flow" Problem, 74 S. CAL. L. REv. 1027 (2001). 
stock liquidated by virtue of a hostile takeover, will also have to bear these transaction costs.

Let us see, however, the effect of a takeover on a customer of a discount broker, our hypothetical Ms. Ina Vestor. Ina has a substantial investment portfolio of $\$ 800,000$, which she has diversified among ten firms, with about $\$ 80,000$ in each. Using the rough average price of stocks in the New York Stock Exchange of $\$ 40$, in order to reinvest proceeds from a hostile takeover of $\$ 80,000$ she would have to purchase on average 2000 shares. $^{373}$ Suppose she is a customer of Charles Schwab \& Co, Inc, a large discount broker, and trades on-line which entitles her to a further discount. The special $\$ 29.95$ per trade commission only applies to trades of less than 1000 shares. $^{374}$ Ina will pay $\$ 0.03$ per share, or on average $\$ 60$ if she invests the entire amount at once (actually in a single day and in one stock-daily trades in a single stock are aggregated for commission purposes). If it takes three trading days of 660 shares each to fill her order, then Ina Vestor will get hit with three $\$ 29.95$ commissions, totaling $\$ 89.85$. Compared with her tax hit, this may seem trivial. We must not forget to take into account the effect of the bid-ask spread as well, which after decimalization has been preliminarily estimated at an average of $\$ 0.07 .^{375}$

If we add these transaction costs to the effect of taxes, however, her return from investing in the market drops further. Using the average stock price of $\$ 40$ and the $\$ 0.03$ per share commission schedule suggests a percentage brokerage fee of $.03 \div 40=0.075 \%$. If we were to repeat the above calculation of her total gains after having paid this fee in year five for the one-third of her investment that was subject to a hostile takeover, we find that her $\$ 100$ capital grows to $\$ 228.80$ instead of $\$ 228.85$ by year ten. ${ }^{376}$ Because of the compounding effect, the loss of

373. The size of this trade also makes it ineligible for a free trade by virtue of a payment for order flow. See infra note 376.

374. For example, Schwab's commission schedule is available on-line at http://www.schwab.com/SchwabNOW/navigation/mainFrameSet/0,4528,717,00.html (last visited Aug. 23, 2000).

375. After the first stage of decimalization-the transition of the pricing of stocks from fractions to dollars and cents-a preliminary study finds the spread to have narrowed by $28 \%$ for the few NYSE stocks that were included in that first stage. See Gaston F. Ceron, Decimalization Cuts Wall Street Profit, Narrowing Bid-Ask Spreads, Says Study, WALL Sr. J., Sept. 8, 2000, at C6 (citing a preliminary report by Professors Robert Wood and Sugato Chakravarty, of the University of Memphis and Purdue University, respectively).

376. The only difference is that instead of investing the full $\$ 50.02$ she received after taxes in the takeover, Ina will pay $0.075 \%$ of that as brokerage commission, and only invest the balance, which will grow, in turn, for five years to $(1-0.00075) * 50.02 *(1+.1)^{5}=80.49729$, say $\$ 80.50$. After paying the $18 \%$ capital gains tax on the gains of $\$ 80.50-\$ 50.02$, Ina is left with $(1-.18) *$ $(\$ 80.50-\$ 50.02)+\$ 50.02=\$ 75.01$ of gains plus capital instead of the $\$ 75.06$ she would have if 
the transaction fee grows and becomes noticeable even if the fee was trivial at the time it was paid.

\section{The Implicit Trading Costs of Unanticipated Takeovers}

The trading of stocks involves one more cost that is not made explicit in the form of a measurable fee or tax. In our world of imperfect information and imperfect ability to process information, the price of any one stock may be higher or lower than its perfectly accurate valuation would suggest. Thus, investors could fully rationally fear that they are buying the overpriced stocks and selling the underpriced ones. Moreover, in addition to this fear which is completely compatible with the evidence about market inefficiencies that we have, investors may also believe that overall prices may not be accurate, that the entire market or sector is mispriced. Then they will fear even larger, more frequent and systemic price discrepancies. Both types of fear create a disincentive to trade. The investor will either not reinvest the takeover proceeds or reinvest and suffer some disutility due to these fears.

Investors will fear trading at false disadvantageous prices for two reasons. First, the evidence of accurate pricing that does exist, only applies to average reactions and does not show that any single stock is accurately priced. Second, there is mounting evidence of inaccurate prices across the entire market. The evidence of accurate pricing that we have is created from averaging across multiple stocks. Most studies find that these aggregated averages react accurately to new pieces of information. ${ }^{377}$ However, they cannot speak about the accuracy of the pricing of each disaggregated stock. The study of uncertainty necessarily involves aggregation, because only in the crowd will the average be captured. Even when we find that aggregation produces correct reactions, the component prices may be inaccurate-some too high, some too low-and the aggregation may hide their inaccuracies. An example will illustrate.

Suppose the uncertain event is a coin toss, one for each of six corporations in a statistical study. If the coin toss comes out heads, the value of the stocks studied will be $\$ 2$, while if it comes out tails the

she had not paid the brokerage fee. Essentially, the $\$ 0.03$ commission of year five has grown to influence the outcome of the tenth year by about $\$ 0.05$.

377. The champion of market efficiency is Eugene Fama. In 1970 he mostly saw indications of efficiency. See Eugene F. Fama, Efficient Capital Markets: A Review of Theory and Empirical Work, 25 J. FIN. 383, 416 (1970). It took a major market crash for Fama to acknowledge some limitations of markets. See Eugene F. Fama, Efficient Capital Markets: II, 46 J. FIN. 1575, 1601-02 (1991). 
stocks will be worth $\$ 1$. The question is whether on the eve of the coin tosses, the market values of these stocks are correctly at $\$ 1.50$. Given the transparency of the example, we know the correct price for each stock. Let us change the coin toss, however, to an uncertain event like the realization of a hostile offer for a corporation. The statistician will aggregate the prices of stocks before and after the realization of the event and see if the price change corresponds to the realized frequency of the event in order to see whether the market anticipates the probability of a hostile offer correctly. Thus, if the offer were the coin toss, the statistician would observe that three corporations received different offers that averaged $\$ 2$ and thereupon the rest of the corporations' stocks dropped to different prices that average $\$ 1$. Given that half of them received an offer, the statistician infers the probability of an offer to be $50 \%$ and examines whether the average price was indeed $\$ 1.50$ before the offer. The statistician will be equally satisfied if all were at $\$ 1.50$ as if half were at $\$ 2.50$ and half at $\$ 0.50$, which still averages $\$ 1.50$. While the latter passes the statistician's test of an efficient market, it is a cause of great concern to the investor because it would be disastrous to buy stock that is at $\$ 2.25$.

The effect of the potential price inaccuracy in a world of prices that are on average accurate suggests that the investor fears trading solitary stocks. If the investor decides to purchase stock in a particular corporation, the investor can be assured that the price is on average correct, but the price may be wrong. The investor is only assured of trading at the correct average price if instead of a solitary stock, the investor purchases many stocks at once. As long as the investor is trading one or even just a few stocks, the investor is justified in fearing that the purchase may be overpriced and the sale underpriced.

In addition to such doubts about the accuracy of prices, there is some evidence that the market as a whole is subject to crowd psychology. Optimistic self-perpetuating buying that raises share prices and panicked selling are frequently reported in the press and in historical accounts. ${ }^{378}$ There is even statistical support for the crowd psychology that ranges from the discount of closed-end funds to the frequency of IPOs of new stocks. ${ }^{379}$ Thus, investors have the fear of false prices not only if they trade a few stocks at a time, but even if they trade many stocks at once.

378. See, e.g., Stephen Labaton, S.E.C. Waives Some Rules to Try to Ease Market Volatility, N.Y. TIMES, Sept. 15, 2001, at C1 (describing moves by the federal government to ward off panicked selling after the September 11, 2001 terrorist attacks).

379. See supra note 319. 
Hostile tender offers that replace investors' stockholdings with cash, by forcing the investors to trade in order to replace their investment, expose investors to the risk of inaccurate prices of individual stocks and inaccurate market levels. ${ }^{380} \mathrm{~A}$ risk-neutral investor would be indifferent to this risk because the over- and undervaluations cancel out. Investors are not risk-neutral but risk-averse with respect to trading because they do not trade diversified-numerous stocks simultaneously. For risk-averse investors, the fear of the possibility of a purchase at a price that is too high is not canceled out by the statistically equivalent possibility of a price that is too low. This prospect is equivalent to a gamble that a prudent person would try hard to avoid. ${ }^{381}$ Thus, the investor will either avoid reinvesting and miss out in market participation that would on average be beneficial, or will suffer through the gamble of trading. The investor in both cases is worse off than without the hostile tender offer.

\section{Preserving Market Attractiveness in the Face of Price Errors}

A further danger that undefendable hostile takeovers pose for investors is a phenomenon known as adverse selection. The term adverse selection denotes the availability of only the worst prospects for investors. ${ }^{382}$ Takeover artists might cherry-pick the market, ${ }^{383}$ leaving only the worst companies for public investment. This generally reduces the possible returns for investors and the attractiveness of the market. Again, if investors achieve superior returns in private investments, they will leave the market, increasing the cost of capital for firms that seek public financing. An example will illustrate this effect.

Suppose, first, that takeover artists are allowed to use hostile bids to remove the firms that are the best candidates for turnarounds from the

380. See Gilson \& Kraakman, supra note 6, at 267.

381. It is simple to analyze this situation mathematically in the context of an investor with constant relative risk-aversion. When facing a fair gamble that half the time, say, increases the investor's wealth by $10 \%$ and the other half reduces it by the same amount, the investor's utility from the gamble is less than remaining with certainty at the current level of wealth. I offer such an example. See Georgakopoulos, The Tortured Transition, supra note 287, at 699-701.

382. See Black, supra note 279 , at 787.

383. The contrary evidence that fund managers cannot cherry-pick against investors is not relevant because fund managers are subject to agency costs and career concerns that distort their incentives against individuality and towards conformism, hence they follow the market. See, e.g., David S. Scharfstein \& Jeremy C. Stein, Herd Behavior and Investment, 80 AM. ECON. REv. 465, 465 (1990) (stating that "professional managers will 'follow the herd' if they are concemed about how others will assess their ability to make sound judgments"); $c f$. Abhijit V. Banerjee, A Simple Model of Herd Behavior, 107 Q.J. ECON. 797, 798 (1992) (discussing the behavior of people in general); Kenneth A. Froot et al., Herd on the Street: Informational Inefficiencies in a Market with Short-Term Speculation, 47 J. FIN. 1461, 1481 (1992). 
public's investment possibilities. The firms that are likely to be attractive to a hostile suitor will probably have management teams that are not reacting to new circumstances. Investors are losing value, but change is not forthcoming from the existing management team. Existing management either fails to realize the need for change, or is resistant to it. Suppose that an undefendable hostile bid arrives. The premise of its level is the implementation of the new strategy for the target. Only a part of the gains from the changed strategy is given to the target shareholders in the form of a bid premium. Once the bid is successful, the further appreciation in value of the target will be captured by the acquirer. Even if the acquirer obtained no more than $50 \%$ of the target's shares, and even if the acquirer split the gains so that $75 \%$ of the appreciation was given to the selling shareholders of the target, the public loses some stock returns. If defensive tactics could delay the hostile change of control, investors may capture the lost returns.

Compare the same setting where Delaware-type defenses give management additional time. ${ }^{334}$ Management will not be able to maintain its resistance to the new strategy. If management tries to solicit a friendly white knight, the viability of the existing strategy will soon emerge as an issue in the negotiations. If management attempts to raise cash for a defensive recapitalization, it will need to raise the productivity of the assets in order to meet its debt payments. If we go down the list of possible defensive measures, as long as management is susceptible to being eventually ousted, the defensive measures that may be imposed will not allow management the wasteful luxury of maintaining its course. Once management is induced to increase the firm's productivity, however, these gains flow to all the shareholders. Thus, even if we suppose that the target management is less able than the hostile suitor to create value, the public shareholders may prefer this gain, particularly given the various tax and transaction cost disadvantages that accompany hostile bids.

Hostile bids, in sum, have a host of ex ante negative effects on investors: tax disadvantages; the imposition of quantifiable transaction costs such as brokerage commissions and the bid-ask spread; the burden of unquantified transaction costs, such as the disutility of more risky trading; as well as the possibility of being prevented from participating in turnarounds. All of these ex ante drawbacks mean that the large premiums that investors realize once a hostile offer does materialize are not a complete definition of the hostile offers' effect on investors, or of

384. See supra Part III. 
the attractiveness that hostile offers contribute to the market. From a social perspective, however, the advantage of hostile takeovers lies not in the premium that investors receive, but in managerial improvement and increased productivity. The possibility of hostile offers has a disciplining effect on management. Defensive measures play a valuable role by allowing target management some time to be disciplined and, thus, have the opportunity of increasing shareholder value without the costs of a hostile bid.

\section{ARGUMENT SUMMARY AND NORMATIVE IMPLICATIONS}

The argument on ownership dispersion and takeover defenses covered such a broad range of fields that it is worth a brief review.

Part IV.A explained that dispersed ownership is necessary for high quality financial markets. ${ }^{385}$ Dispersed ownership allows investor diversification, which is necessary for the equity market to be a means of saving. ${ }^{386}$ This not only increases the relevance of the equity market for corporate financing, but also induces risk-neutral management of economic resources. The trading activity that is motivated by investment purposes creates market liquidity, which attracts informed trading. Informed trading increases the accuracy of prices. ${ }^{387}$ Increased price accuracy also means reduced risk, which further attracts investment activity ${ }^{388}$ Lack of takeover defenses would induce entrepreneurs to retain control of their enterprises. This would counteract the benefits of dispersed ownership and produce additional ills. Widespread retention of control combined with decreased market quality would bias firms toward internal growth as opposed to the financing of independent startup corporations. This would slow economic mobility by both producing large bureaucratic corporations and by reducing independent innovation. Innovation is also directly facilitated by defenses. Defenses increase the value of control, adding value to the venture capital arrangement.

Part IV.B explained that dispersed ownership provides CEOs with a substitute of diversified human capital because their performance is evaluated by the entire market rather than a single boss. ${ }^{389}$ The danger of temporarily low prices, however, exposes the management of the public

385. See supra notes $287-95$ and accompanying text.

386. See supra notes 297-99 and accompanying text.

387. See supra note 302 and accompanying text.

388. See supra Part IV.A.3.

389. See supra Part IV.B.2 
corporation to the risk of a takeover that is not justified by their poor performance. Takeover defenses mitigate this problem. ${ }^{390}$ At the same time, dispersed ownership ensures that poor management will be replaced. ${ }^{311}$ Takeover defenses that produce entrenched control prevent the operation of this crucial function.

Part IV.C explained that technological evolution presents the risk of widespread workforce dislocation. Old skills lose value and the skills required by the new technology are still being learned. Ownership dispersion with takeover defenses retards the transition process. Managers whose positions are protected by takeover defenses can afford wasteful delay in adopting new technologies that would disrupt their employees. This delay releases some of the socioeconomic pressures of adapting to a new technology.

All these effects-diversification, risk-neutral management, market liquidity, the enhancement of venture capital contracting, the evaluation of CEOs by the market, and graduated technological adoption-have benefits that are not appropriated in their entirety by each corporation. Dispersed ownership in one corporation allows investors to diversify their holdings in, and produces liquidity in, other corporations as well. ${ }^{392}$ The gains in terms of reduced cost of capital, risk-neutral management, more liquid markets and accurate prices, are gains that are shared. Thus, the amount of defenses that firms provide will tend to be sub-optimal from a social standpoint.

Part IV.D explained that unanticipated takeovers erode investor returns by triggering tax realization, exposing investors to explicit and implicit transaction costs. ${ }^{393}$ Furthermore, unanticipated takeovers allow buyout funds to cherry-pick the market, exposing investors to the "adverse selection" cost of having the most promising corporations removed from their portfolios. ${ }^{394}$ Takeover defenses mitigate these dangers. This makes equity investments more attractive and reduces firms' cost of capital..$^{395}$

The interaction of these arguments brings us closer to determining optimal takeover defense intensity. The first and last arguments illustrate

390. See id.

391. See Zenichi Shishido, Japanese Corporate Govemance: The Hidden Problems of Corporate Law and Their Solutions, 25 DEL. J. CORP. L. 189, 218-19 (2000); David A. Skeel, Jr., An Evolutionary Theory of Corporate Law and Corporate Bankruptcy, 51 VAND. L. REV. 1325, 1339 (1998) (stating that "[p]oorly run firms may be subject to a takeover").

392. See Skeel, supra note 391, at 1334.

393. See supra notes 367-77 and accompanying text.

394. See supra notes 382-84 and accompanying text.

395. See supra Part IV.D.4. 
that dispersed ownership and takeover defenses are required conditions for the functioning of financial markets. The second and third arguments relate ownership dispersion and the intensity of takeover defenses to the market for control of corporations and the speed of technological change. Ownership dispersion with weak defenses exposes skilled management to false takeovers and their precarious hold on control forces immediate adoption of new technologies. Concentrated ownership with strong defenses allows the entrenchment of incapable managers. ${ }^{396}$ Thus, the optimal takeover defense intensity is a complex product of various features of the economic environment, including ownership dispersion, the speed of technological innovation, as well as the quality of the financial markets.

Of course, even though Delaware law has reached the point where the bidder's dispersion influences directly the intensity of the takeover defenses that can be implemented, this sensitivity to dispersed ownership is limited to the context of defending a merger. ${ }^{397}$ The examination of Delaware law showed that its structure indirectly promotes dispersed ownership in all settings, not just merger defenses. ${ }^{398}$ Therefore, the question arises about what further sensitivity to ownership dispersion should corporate law show?

The first issue is whether defenses should depend on the acquirer's dispersion. Note that one of the most important contributions of takeover defenses was the insulation of skilled management from false takeover attempts. This contribution of takeover defenses would disappear if they could only be used against acquirers of concentrated ownership. One more advantage of defensive tactics was that it prevents adverse selection: the removal from the portfolio of the public investors of the most attractive opportunities. If the acquirer is a public enterprise, this fear is not as strong. Truly well-diversified investors would still participate in the opportunity, but through their investment in the acquirer instead of through the target. Note, however, that this presents a host of complications that may be desirable to avoid, such as the danger of producing conglomerates, ${ }^{399}$ and the loss of the evaluative function of

396. See supra Part II.B.2.

397. Delaware law is explicitly sensitive to dispersed ownership in this setting because of the QVC decision. See supra notes 116-18 and accompanying text, where the court struck down defenses protecting a merger that would give control of the combined entity to an individual.

398. See supra Part III.B.

399. The Time decision can be argued to indicate such a danger, but this fear is probably wrong. The Time court allowed defenses to protect a strategic alliance of two public companies, see Paramount Communications, Inc. v. Time, Inc., 571 A.2d 1140, 1155 (Del. 1989), and its decision may be thought, therefore, to allow or induce conglomeration. The more optimistic outlook would 
the independent market for the target's shares. A drive toward conglomerates would also narrow the managerial pool. This would make rare innovations less likely, and would hinder their emulation because the increased performance of the innovating company would be hidden deep in a conglomerated firm. ${ }^{400}$ Thus, although dispersed ownership is an admirable side-benefit of defensive tactics, the argument that defensive tactics should hinge on the acquirer's ownership dispersion is not strong.

Optimal defense intensity appears to increase as ownership becomes more dispersed. More dispersed ownership implies that the management team owns a smaller fraction of shares in the firm than under more concentrated ownership. Thus, their control is more vulnerable to the development of an insurgent set of stockholders, whether those are existing holders or a new acquirer. This vulnerability implies that a temporary drop in the stock's price exposes management to a greater risk of a takeover. Since the drop in price is not the result of poor management, this is a takeover that has no direct or indirect beneficial effects of disciplining management of either this or other corporations. Moreover, the fear of such a situation is undesirable to the management team. Takeover defenses cure this problem by preventing a fast takeover at a time of temporarily low prices. Therefore, the more dispersed ownership is, the stronger defenses a firm should have. This analysis should be extended to the legal system as a whole. In order to forestall disruptive, inefficient takeover attempts at times of temporarily low prices, a legal system with very dispersed corporate ownership should provide stronger defenses than one with less dispersion.

Optimal defense intensity also appears to increase with the speed of technological innovation, provided that the legal system has managed to produce dispersed ownership. Given dispersed ownership, defenses allow managers some indulgence of not pressing for immediate adoption of new technologies. The transition to the new technology may produce a bottleneck of mass layoffs and retraining pressure. Allowing management some inefficient delay may be desirable for society as a

\footnotetext{
argue that the quality of the strategic alliance was part of the court's thought process and that the protection of Time would not be afforded to inefficient conglomerations. A different concern about Time would be that it may lead to a reduction of the number of available investments, creating concerns about diversification and market liquidity. Neither are correct. Strategic mergers do not reduce diversification of investors because the component firms are still indirectly part of investors' portfolios. Market liquidity should actually benefit from strategic mergers since the reduction in the number of tradable companies implies that the combined entities are traded even more intensely.

400. These benefits of dispersed ownership were discussed above. See supra notes 295-96 and accompanying text.
} 
whole. Takeovers are not as threatening when firms are under concentrated ownership. The pressure to adopt the new technology may not be as strong. Defenses may reduce this pressure even further, but this delay may be excessive. Therefore, optimal takeover defense intensity depends on both the speed of technological progress and the concentration of ownership. Strong defenses will not help resolve retraining bottlenecks in legal systems with concentrated ownership as much as in those with dispersed ownership.

Finally, the premise of these arguments, the possibility of false prices, shows one more direction in which the law could move. If the degree of accuracy of the price of a stock can be ascertained, then the intensity of available defenses should vary accordingly. Defenses should be allowed more generously if the firm's stock price is inaccurate, because the possibility of an inaccurately low takeover price is stronger. Defenses to protect from takeovers at inaccurately low prices are unnecessary if a stock's price is very accurate. Therefore, optimal takeover defense intensity depends on the ex ante accuracy of stock prices. This sensitivity, however, is already evident in the Delaware courts. Target management often makes the argument that the hostile offer undervalues the target and its shareholders should be protected from accepting the inadequate offer. In response, a significant part of the Delaware courts' efforts is already expended in the task of ascertaining price accuracy. ${ }^{401}$

In sum, optimal takeover defense intensity should depend on ownership dispersion, pace of technological innovation, and the accuracy of stock prices. Counterintuitively, the acquirer's dispersion may not be of significant concern.

\section{A. Whither Europe?}

The stance of the European legal system on takeover defenses contains several paradoxes. The Second Directive on Company Law precludes the development of the discriminatory defenses that have allowed corporations in the United States to avoid running into the folds

401. That defenses seek to protect sharehoiders who will be induced to sell at an inadequate price is such a consistent refrain in Delaware law that it has fueled significant commentary. See, e.g., Robert B. Thompson, Shareholders as Grown-Ups: Voting, Selling, and Limits on the Board's Power to “Just Say No," 67 U. CiN. L. REv. 999 (1999); Neil C. Rifkind, Note, Should Uninformed Shareholders be a Threat Justifying Defensive Action by Target Directors in Delaware?: "Just Say No" After Moore v. Wallace, 78 B.U. L. REV. 105 (1998). 
of white knights. ${ }^{402}$ American corporations can elect to give their board of directors the authority to issue securities, and the board has the authority to repurchase shares of the corporation. ${ }^{403}$ Poison pills are implemented by the issuance of a security resembling convertible preferred stock that gives friendly shareholders valuable rights in the event of a hostile acquisition. ${ }^{404}$ Repurchases have been used defensively by targets that threaten to dilute the target's value by excluding the hostile acquirer from the repurchase. ${ }^{405}$

Neither poison pills, nor greenmail, nor selective self-tenders akin to Unocal's are possible under the Second Directive. ${ }^{406}$ Thus, the principal self-help measures that American targets use to avoid inopportune hostile offers are precluded from developing in Europe. The question of what discrimination against hostile shareholders may be allowed is not reached under European corporate law. Moreover, European law shows express hostility to defenses. Some legal systems, such as that of the United Kingdom, expressly prohibit defenses.

In order to facilitate the pursuit of dispersed ownership by a legal system, such as that of the European Union, we must first establish how the system might currently promote dispersed ownership. In the context of Europe's hostility to defenses and the associated attempt to specify and circumscribe the powers of managers, ${ }^{403}$ the motivating factors are not only a suspicion of corporate managers but also a tradition and

402. See Second Council Directive 77/91 of 13 December 1976 on Coordination of Safeguards Which, for the Protection of the Interests of Members and Others, are Required by Member States of Companies Within the Meaning of the Second Paragraph of Article 58 of the Treaty, in Respect of the Formation of Public Limited Liability Companies and the Maintenance and Alteration of Their Capital, with a View to Making Such Safeguards Equivalent art. 19, sec. 2, 1977 O.J. (L 26) 1 , reprinted in FOLSOM, EUROPEAN UNION SOURCEBOOK 3.D.2 (1995). The Second Directive mandates equal treatment of shareholders in article 42 , precluding greenmail, discriminatory self-tender offers for the shares of the target that would exclude shares held by the acquirer, and poison pills which grant rights that do not accrue to the acquirer. Nevertheless, article 19, section 2 allows repurchases to avoid "imminent harm." The target's board can, if it has followed the proper procedure and obtains authority every five years, issue shares without shareholder approval. See id. art. 25 sec. 2.

403. See supra text accompanying notes 73-107.

404. See supra notes 75-78 and accompanying text.

405. See supra notes 93-107 and accompanying text, discussing Unocal.

406. See supra note 402.

407. See supra Part II.B.1.

408. See SMON JOHNSON ET AL., TUNNELING (Nat'l Bureau of Econ. Research, Working Paper No. 7523, 2000) (finding that the formalist protection of the minority by civil law systems actually leads to overreaching by controllers who use technically legal transactions to divert or "tunnel" value away from the minority). 
system of judicial passivity. ${ }^{409}$ Under the rubric of protecting shareholders, continental European legal systems are reluctant to extend the authority of corporate managers. ${ }^{410}$ While effective shareholder protection will likely lead to dispersed ownership, continental Europe does not seem to have achieved it, because truly dispersed ownership is still the exception among continental corporations. ${ }^{411}$ Furthermore, European legislators cannot be argued to harbor a malicious intent, for example that they pursue an objective other than welfare maximization or that they are "captured" by hostile acquirers. Obviously, no support can be garnered for such a belief-crossing the Atlantic does not change the popularity of hostile acquirers. By contrast, many European legislative choices would tend to lend support to a view that continental legislatures may be captured by populist forces, making the welcoming environment that Europe is creating for hostile acquirers all the more paradoxical. $^{412}$

The only possible way in which a bar on defenses can be considered to promote dispersed ownership is by facilitating the acquisition of less dispersed targets by more dispersed acquirers. In a legal system that does not produce dispersion in the natural course of corporations' financing and growth, it is conceivable that some inducement of dispersed ownership is better than none. Note, however, that one would not by design choose such a means of producing dispersion. The mechanism is faulty because targets are more likely to have dispersed ownership than acquirers. Because hostile takeovers consist of a purchase of a controlling block, targets are by definition not subject to a lock on control. Thus, targets are either subject to working

409. See Nicholas L. Georgakopoulos, Independence in the Career and Recognition Judiciary, 7 CHI. ROUNDTABLE 205 passim (2000) (stating that the institutional structures of the civil bench promoted the widely observed judicial passivity); Nicholas L. Georgakopoulos, Predictability and Legal Evolution, 17 INT'L REv. L. \& ECON. 475 passim (1997) (stating that the rare large changes of the law that perforce occur in a civil law system of judicial passivity are undesirable from the perspective of risk-averse members of society who prefer the frequent small changes of common law judicial activism).

410. See Black \& Kraakman, supra note 42 , at 1962 n.105.

411. See supra notes $250-52$ and accompanying text.

412. In the very area of corporate law, consider the German choice of employee "codetermination," the mandatory participation of employees in the "supervisory board" of all large corporations. See Mark J. Roe, German Codetermination and German Securities Markets, 1998 COLUM. BuS. L. REV. 167, 167. The European Union was ready to impose codetermination in the early Seventies with the version of the Fifth Directive that was proposed then, and only the entry of the United Kingdom into the European Union and its opposition to codetermination prevented codetermination from becoming the European Union norm. See, e.g., Bridget Montgomery, Comment, The European Community's Draft Fifth Directive: British Resistance and Community Procedures, 10 COMP. LAB. L.J. 429, 431-37 (1989). 
control or have truly dispersed ownership. Acquirers, on the other hand, are not restricted in the way they are controlled. They are as likely to be subject to a lock on control as to dispersed ownership. Essentially the only stable state to which the device of ephemeral control can lead is the lack of concentrated ownership in all corporations, which will occur when the last corporation of dispersed ownership is acquired. At that point takeovers disappear, as does the need for defenses. If, counterintuitively, takeovers manage to expand dispersed ownership, then the continent would need takeover defenses so as to protect this dispersed ownership. The continental European takeover law, thus, is inherently unstable from an evolutionary perspective. ${ }^{413}$ However, this point is not completely missed by European policymakers. It is interesting to note the French government's attempt to establish semipermanent shareholder groups as its firms try to produce more dispersed ownership. ${ }^{414}$

Accusing the European takeover law environment of being defective must give way to constructive criticism. The defects of European takeover law pale compared to the inability of continental corporate law to produce dispersed ownership.

Before finding European takeover law innocent of being a principal cause of concentrated ownership, we must remember that dispersed ownership existed in the United States and the United Kingdom long before the current ease of hostile takeovers. The ease of hostile takeovers increased vastly when Michael Milken allowed easy financing of large cash takeovers by applying the lessons of diversification so as to reduce the risk of those who financed takeovers. ${ }^{415}$ The time at which hostile acquisitions became a noticeable threat is relevant because, as I argued, the possibility of a hostile takeover influences the attractiveness of the

413. It is easy to find historical traces of defenses following dispersed ownership. In the late nineteenth and early twentieth centuries, the maintenance of dispersed ownership in Japanese cotton mills was facilitated by measures that were essentially defensive, which reduced the voting power of large blockholders by reducing the votes of shares beyond some number to one-fifth or even onetenth of a vote. See Yoshiro Miwa \& J. Mark Ramseyer, Corporate Governance in Transitional Economies: Lessons from the Prewar Japanese Cotton Textile Industry, 29 J. LEGAL STUD. 171, 197-99 (2000). Similarly, Gilson \& Roe assign to the cross-holdings of Japanese keiretsu an antitakeover role. See Gilson \& Roe, supra note 26 , at 897-88.

414. Lauren Aste reports that as Société Générale, AXA, Crédit Lyonnais, Alcatel Alsthom, and Rhône-Poulenc have tried to reduce cross-ownership arrangements in which they participated so as to produce privatized dispersed ownership, the French government has fostered the creation of "stable shareholder groups" ("les groupes d'actionnaires stables"). See Aste, supra note 251, at 17.

415. See Lawrence A. Cunningham, The Essays of Warren Buffett: Lessons for Corporate America, 19 CARDOzo L. REV. 1, 102-03 (1997) (compiling and introducing essays authored by Warren E. Buffett). 
position of managing a firm under dispersed ownership. Go back to the incentives of entrepreneurs to take their companies public and to produce dispersed ownership by selling or allowing the dilution of their stake. The founders' incentive to produce dispersed ownership is weakened as the threat to control becomes more pronounced. In other words, before takeovers it was easier for a legal system to produce the incentives that would lead to dispersed ownership, because the fear of takeovers was not a concern. Now that takeovers have become a concern, for dispersed ownership to be produced, a legal system needs to address two issues. Minority shareholders must be adequately protected so as to reduce the minority discount. Furthermore, the legal system must counter the founders' concern that the control they will be left holding after dispersing their corporations' ownership may be ephemeral. Thus, the "defense-less" takeover law of Europe is increasingly accountable for the continent's failure to produce dispersed ownership. The easier takeovers become, the stronger the founders' disincentive to surrender their lock on control.

\section{B. Whither America?}

The law in the United States, despite varying greatly between Delaware, and Indiana's followers, agrees with my analysis. In some aspects the agreement is striking. Delaware law has even expressly taken ownership dispersion into account as a factor that determines the appropriate defense intensity. The $Q V C$ decision invalidated Paramount's defenses largely because they were protecting a transaction that would lead not simply to concentrated ownership but to a lock on control. ${ }^{416}$ As the Delaware Supreme Court remarked, the merger would be scrutinized because it would result in the combined entity having a majority stockholder:

In the absence of devices protecting the minority stockholders, stockholder votes are likely to become mere formalities where there is a majority stockholder.... The acquisition of majority status and the consequent privilege of exerting the powers of majority ownership come at a price. That price is usually a control premium which recognizes not only the value of a control block of shares, but also compensates the minority stockholders for their resulting loss of voting power.

416. See Paramount Communications, Inc. v. QVC Network, Inc., 637 A.2d 34, 51 (Del. 1993). 
In the case before us, the public stockholders (in the aggregate) currently own a majority of Paramount's voting stock.... Following [consummation of the merger], there will be a controlling stockholder who will have the [majority] voting power. ${ }^{417}$

Thus, the courts are already sensitive to ownership dispersion in evaluating defensive tactics. This sensitivity, however, can be refined in view of the additional light that this analysis has shed on its function. Four aspects of the sensitivity to dispersion are open for the application of the lessons of this Article.

First, the arguments of this Article suggest that we must evaluate how the ownership dispersion of the target should influence the intensity of the defenses its managers can use. Because the dispersion of the target implies greater vulnerability for management, the potency of the takeover defenses that management should be allowed to use should increase as the stake of management in the firm becomes smaller. A trace of such a sensitivity may be garnered in the, later reversed, decision of the Court of Chancery in Unitrin. ${ }^{418}$ The repurchase plan that management proposed would have increased its stake to allow an absolute veto on corporate combinations due to a $75 \%$ supermajority requirement in the target's bylaws. ${ }^{419}$ Since the board was starting with a $23 \%$ stake, $^{420}$ its position was fairly safe, and it should only be allowed weak defenses. Ironically, the reversal by the Delaware Supreme Court ${ }^{421}$ does not refute this statement. It allowed the defensive repurchase because it considered that management's stake was already enough to veto corporate combinations given the usual abstentions from shareholder votes. ${ }^{422}$ Going forward, however, this Article argues that courts should become less permissive with defenses as management's share ownership increases. The increase implies reduced fear of a takeover, and the use of defenses raises the concern that management is avoiding the disciplining effect of the market for corporate control.

A further complication arises particularly in the case of a judiciary as specialized in corporate disputes as that of Delaware. Great confidence in the judiciary would imply that it may be given virtual

417. Id. at $42-43$.

418. See Am. Gen. Corp. v. Unitrin, Inc., Nos. CIV.A.13699, 13656, 13663, 13665, 13676, 13685, 13684, 1994 WL 512537 (Del. Ch. Aug. 26, 1994); In re Unitrin, Inc., S'holders Litig., Nos. CIV.A.13656, 13699, 1994 WL 698483 (Del. Ch. Oct. 14, 1994), rev'd, 651 A.2d 1361 (Del. 1995).

419. See Am. Gen. Corp., 1994 WL 512537, at *2; In re Unitrin, Inc., 1994 WL 698483, at $: 3-4$.

420. See Am. Gen. Corp., 1994 WL 512537, at *2; In re Unitrin, Inc., 1994 WL 698483, at *4.

421. Unitrin, Inc. v. Am. Gen. Corp., 651 A.2d 1361 (Del. 1995).

422. See id. at 1383 . 
carte blanche to establish the desirability of defenses on a case-by-case basis. Perhaps the Delaware judiciary is able to balance not only defense intensity but also managerial skill, the strength of competing strategic visions and all concerns that influence the social welfare that takeovers produce. Such an ad hoc system, however, would produce the desired incentives for neither corporate management nor entrepreneurs. Thus, even if some vague balancing remains, target dispersion should be a separate express concern. This will allow clearer use of the other undefined concerns by the courts. Moreover, the express influence of target dispersion will sharpen the incentives for economic productivity.

The arguments of this Article suggest that courts must also evaluate the two factors that influence the concentrating effect of takeovers-the accuracy of the market price and the speed of technological developments. The accuracy of the market price reduces the threat of false takeovers. Therefore, courts should be more reluctant to uphold defenses in the face of evidence of an active and accurate market for the target corporation's shares. Delaware courts engage the question of price accuracy already, because it is a consistent claim of the target management that the hostile offer undervalues the target corporation and, therefore, shareholders should be protected from selling their shares at the low price offered. ${ }^{423}$ This is probably an aspect where Delaware practice, although unacknowledged, is in perfect congruence with the normative recommendations of this Article.

The speed of technological change increases the benefit from graduating the adoption of the new technology. The benefit that defenses bestow in this context is external to managers and shareholders. It consists of the social gain from the reduction of the pressure to acquire the new skills. The ramifications of the pressure to acquire new skills will differ depending on the size of the market imperfections, which are likely to be large, since the setting is akin to the market for education. When technological change is unfolding at a brisk pace neither employees nor employers are likely to be able to estimate the gains from adoption with great precision so as to ration their demand for retraining in the new technology. When courts see a new technological wave building up, they can protect society from the dislocation and the shock of a radical switch to the new technology by granting target management some more latitude with defenses.

The problem with this point is that it is one that target shareholders are not internalizing ex ante. Shareholders do not have an incentive to

423. See supra note 401 . 
wastefully delay their own firm's adoption of the new technology in order to alleviate the social pressures that a retraining bottleneck may cause. The privately optimal decision of shareholders would lead to underprovision of defenses from a social standpoint. This discrepancy needs to be remedied, and solutions are easy to craft.

The solution to the underprovision of defenses lies in the ex post divergence of interests between shareholders and management. After a hostile offer has taken place, management has a strong incentive to defend its control and exceed the ex ante limitations that shareholders place on the use of defenses. To illustrate this effect, imagine that shareholders could authorize defense use by the delay it would impose on a change of control. Thus, even though shareholders would authorize defense use up to a 120-day delay, management has the ex post incentive to use defenses that will delay the acquirer more than 120 days in obtaining control. Such precise description and authorization of defenses does not correspond to reality.

The example points toward a solution to the conflict between privately and socially optimal defense intensity. Shareholders cannot authorize defense use according to the delay that defenses cause on changes of control. Defense use is authorized in general terms, such as the ability of management to authorize the issuance of new securities. This authority, applied to defenses, means the ability to issue poison pills. The vagueness of this type of authorization means that ex post conflicts will arise, since managers will tend to push the envelope of the tools that they have in the direction of more defenses. For example, they may authorize and issue poison pills with stronger terms than shareholders would have ex ante approved. To the extent this happens, the solution is a simple deference by the courts to the managerial decision. As long as management can exceed the ex ante authorization, the privately excessive defenses that management institutes are likely to approach the social optimal. Management should not be allowed too much leeway, however, because it could be excessive and produce control that is more entrenched than optimal. Particularly in the interpretation of the propriety of poison pills and similar defenses of broad discretion, courts can easily further social welfare, and they arguably already do.

The law should not, however, be structured so as to prevent shareholders from placing any limit on managers' ability to defend control. The Unocal defensive self-tender is a typical example of a type of transaction that can be crafted despite vastly exceeding the 
authorization for defenses that shareholders have given. Thus, it is only appropriate that the SEC has banned such practices. ${ }^{424}$

We have established, however, that the social need for defenses is strong only in times of radical technological change, because of the potential bottleneck that demand for mass retraining in transferable skills may cause. As courts balance how much leeway to give to the managerial choices regarding defenses, courts should take into account the pace of technological change. The amount by which courts err in management's favor should increase as the speed of technological change increases.

The last concern takes us back to $Q V C$. Either $Q V C$ may be interpreted too broadly or the conclusions of this Article too narrowly. I argue that we should not read $Q V C$ to only or mainly allow defenses against concentrated acquirers. The problem is not so much in what $Q V C$ does say, but rather in what the court might be interpreted as saying. The narrow holding, that the courts should scrutinize defenses that protect a merger that would concentrate ownership, is perfectly appropriate from the perspective of promoting dispersed ownership. The expansion that must be avoided would be the reverse of this positive holding: that defenses of mergers that do not concentrate ownership are always appropriate. Unfortunately, the Time decision that is so closely bound with $Q V C$ does leave that avenue open. Indeed, Time was considered a revival of the "just say no" approach to defensive tactics. ${ }^{425}$ According to the "just say no" approach, the target has no obligation to ever remove

424. In response to Unocal's embracing of discriminatory tender offers, the SEC changed its regulation of tender offers so as to preclude defensive discrimination in tender offers. See SEC Tender Offers By Issuers Rule, 17 C.F.R. $\$ 240.13 \mathrm{e}-4(\mathrm{f})(8)$ (i) (2001); SEC Equal Treatment of Security Holders Rule, 17 C.F.R. $\$ 240.14$ (d)-10 (2000) ("No bidder shall make a tender offer unless ... The tender offer is open to all security holders of the class of securities subject to the tender offer...."). Thus, the Unocal discriminatory and coercive defense would no longer be available without being incorporated into a preexisting poison pill. Although my arguments support defenses, they do not argue for returning the regulation of tender offers to their old state so that discriminating self-tenders would be available. The rationale for disallowing discriminating selftenders is bolstered by the fact that the same defense is available in the form of the poison pill, with the additional advantage that shareholders can choose whether to allow their board to have or not the authority to issue securities and, hence, the pill. Thus, shareholders can limit the use of discriminatory defenses as long as the defenses must be implemented through a poison pill. If discriminatory defenses could be implemented by means of a self-tender, then limiting their use by management would be much harder if not impossible for shareholders.

425. See, e.g., Mark J. Loewenstein, Recent Judicial Developments In Delaware Takeover Law, Colo. LAW., Jan. 1990, at 47, 48; Thompson, supra note 401, at 1007; Rifkind, supra note 401 , at 126. 
defenses that thwart hostile suitors. ${ }^{426}$ Naturally, such an approach would decimate the market for control and its desirable disciplining effect on management.

The inescapable realization is that optimal takeover defense intensity is a much more complex concept than revealed by the few considerations on which this Article focuses. Even the identification of the factors that courts should use is shrouded in obscurity. Many cases can be read as taking into account the inadequacy of the price that the acquirer would offer. Interco can be read as taking into account either poor strategy, or more specifically, a strategy of conglomeration without operating synergies. ${ }^{427}$ In the same vein lies TW Services, Inc. v. SWT Acquisition Corp. ${ }^{428}$ where inadequate price along with the existence of synergies among the target's businesses and apparent lack of a strategic motivation behind the acquirer, led the court to allow the defenses to stand. ${ }^{429}$ Defensive deconglomeration without any strategic justification

426. See John H. Matheson, Corporate Govemance at the Millenium: The Decline of the Poison Pill Antitakeover Defense, 22 HAMLINE L. Rev. 703, 730 (1999).

427. See City Capital Assocs. v. Interco, Inc., 551 A.2d 787 passim (Del. Ch. 1988). The Interco decision also shows that the value of dispersed ownership is not absolute. See id. at 794-95. Dispersed ownership will not be protected in the face of poor long-term strategy. See id. at 791. City Capital was a concentrated acquirer, essentially owned and financed by two brothers. See id. at 791 $\&$ n.2. The target, Interco, was under dispersed ownership. See id. at 791. Faced with an all-cash allshares hostile offer, the Interco management planned a restructuring in which half of the income producing assets of Interco would be sold, debt repaid, and preferred stock issued to existing shareholders. See id. at 793. The ownership concentration of Interco would not change by means of this defensive transaction, but neither would its strategy. Interco was a conglomeration of various businesses. See id. at 791 . Even in cases where Interco had several subsidiaries in the same business, they may not be integrated, as in the example of its two furniture businesses, "Ethan Allen" and "Lane and Broyhill." See id. at 793-94.

428. Nos. CIV.A. 10427, 10298, 1989 WL 20290, at *1 (Del. Ch. Mar. 2, 1989).

429. See id. at "11-12. TW Services validates the "just say no" defense. The target, TW, was a collection of service businesses that remained from the old TWA, after airline and hotel operations were separated. See id. at *2. It included restaurant chains and nursing homes. See id. The acquirer, SWT, was a vehicle of Coniston Partners, an LBO fund of concentrated ownership and without potential for acquisitions motivated by strategic synergies. See id. SWT acquired over 19\% of TW before launching its tender offer conditional on a removal of the poison pill. See id. at *3-4. TW refused to remove the pill and refused to talk with SWT unless all of the conditions of the offer were removed. See id. at *4-5. TW considered SWT's bid insufficient, designed to start a bidding war in which SWT would profit by selling its TW shares to the highest bidder. See id. at *4-5. With the argument that any merger or defensive recap would impair the ability of the corporation to raise the financing that its Denny's chain needed, management refused to negotiate. See id. at *11. Ultimately, the court agreed with management's argument that since the tender offer was conditional on the board's agreement to a merger, the board actions must be judged under the traditional business judgment standard for refusing a merger proposal. See id.

For a recent discussion of the Kohlberg Kravis Roberts \& Co. strategy of synergistic buyouts, see generally GEORGe P. BAKER \& GEORGE DAVID SMTTH, THE NEW FINANCIAL CAPITALISTS: KOHLBERG KRAVIS ROBERTS AND THE CREATION OF CORPORATE VALUE (1998). 
seems to have also led the court to order the removal of defenses in Grand Metropolitan. ${ }^{430}$

After discussing so much of defense law, it would be negligent not to revisit the issue of false biases against strategic mergers. As discussed above, Delaware bars a merger for three years after a takeover unless the target has opted out of this protection or the target approves the acquisition. ${ }^{431}$ This is a biased defense because it has a different influence on acquirers motivated by financial gain and those motivated by a desire to achieve gains from implementing strategic synergies. Financial buyers are not impeded by this provision, while strategic buyers may need a merger in order to fully integrate the combined corporations and implement the plan that will lead to the synergies. This is clearly the wrong bias from a policy perspective, since strategic mergers should be impeded less than acquisitions made from financial gain alone. A surprising twist on this theme, however, is offered by the proposal of the independent directors of Digex, Inc., to decline to waive the bar on mergers for an undesirable acquirer.

Digex was put up for sale by its controller, Intermedia Communications, Inc. ${ }^{432}$ The auction was conducted by the independent directors on Digex's board. ${ }^{433}$ One of the several offers, however, was not for Digex but for its parent, Intermedia. ${ }^{434}$ The terms were less favorable to Digex than other offers, but so favorable for the parent shareholders that the parent accepted the merger. ${ }^{435}$ One of the conditions of the bidder was the waiver of the three-year prohibition on mergers that Delaware imposes by default. ${ }^{436}$ The acquirer desired the ability to merge Digex with itself or subsidiaries. ${ }^{437}$ The independent directors of Digex recommended that the prohibition on mergers not be waived. ${ }^{438}$ Thus, the target minority shareholders were seeking to use against the controller a provision that is intended to favor the controller. The court,

430. See Grand Metro. Pub. Ltd. v. Pillsbury Co., 558 A.2d 1049, 1055-56 (Del. Ch. 1988). The Board's proposed defense would spin-off Burger King (Pillsbury's crown jewel) and various other businesses, without any strategic justification for separating the various food businesses of Pillsbury. See generally $i d$. The court ordered redemption of the pill and enjoined the spin-off or sale of Burger King. See id. at 1061.

431. See supra note 343 and accompanying text.

432. See Deborah Solomon \& Nikhil Deogun, Digex Sale Reflects Minority Holders' Secondary Status, WALL ST. J., Sept. 8, 2000, at C1.

433. See id.

434. See id.

435. See id.

436. See id.

437. See id.

438. See id. 
on motion for a preliminary injunction, agreed that the plaintiffs had a reasonable chance of success on the merits of their claim that the removal of the three-year bar on mergers was a fiduciary violation. ${ }^{439}$

\section{CONCLUSION}

The ranks of academic research are brimming with new articles on corporate governance. Since both takeover defenses and the strength of the incentive to produce dispersed ownership are central elements in any set of corporate governance choices, this Article comes to join those ranks. As the vacillations of the corporate governance literature show, the optimal corporate governance is a moving target and depends on the surrounding environment of laws and other norms. Optimal takeover defense intensity can only be conceived in a sterile environment of a mathematical model. In the quest for the perfect corporate governance mechanism, however, we must not forget its multidimensional texture and constantly evolving dynamics. A recipe for perfect corporate governance can no easier be created by black and white rules than justice can be provided by automata. Thus, in all the strides that recent scholarship may be making, we must remember that our answers are always partial. The environment of rules and social norms, within which corporate governance unfolds, will interfere with the transportation of solutions from one jurisdiction to the other.

Incentives, however, are inescapable shapers of human activity. In engaging a limited aspect of corporate governance-defenses and dispersed ownership-rather than seeking an overarching and allencompassing view, this Article accomplishes necessarily less than more general ones, but also much more. My conclusions apply to every jurisdiction insofar as dispersed ownership requires some protection from hostile attacks. However, the optimal protection in each jurisdiction is very likely to differ from the protection of control that Delaware provides.

Essentially, in this Article I have tried to examine dispersed ownership as one of the elements that enter the mix of economic productivity and to study how it is influenced by defenses. Defenses alleviate a threat to control, but also mitigate the discipline that a vigorous market for control imposes on managers. The above arguments imply that ownership dispersion, the speed of technological change, and the accuracy of the stock's price, predicts firms' choices regarding

439. See In re Digex, Inc., No. CIV.A. 18336, 2000 WL 33671760, at $* 1,16$ (Del. Ch. Dec. 13, 2000). 
takeover defense intensity. More importantly, these arguments recommend the attitudes that courts should have in interpreting managers' defensive powers. Furthermore, the study of corporate governance benefits from this Article. Some of the complexity of corporate governance becomes transparent. Further research that will promote the understanding of corporate governance and its use to enhance productivity, is facilitated. The idea that we can then take this recipe and blindly apply it to French, German, or even Chinese and Russian firms is ludicrous. The devastating effect of Western economics and law in Russia warns of the results of such hubris. ${ }^{40}$

440. Russian privatization was engineered by a Harvard economics professor of Russian origin, Andrei Shleifer, and the reform of Russian corporate law was led by law professors at Harvard and Columbia, Reinier Kraakman and Bernie Black. Their explanations for the failure of the reforms are in ANDREI SHLEIFER \& DANIEL TREISMAN, WITHOUT A MAP: POLITICAL TACTICS AND ECONOMIC REFORM IN RUSSIA (2000), and Bernard Black et al., Russian Privatization and Corporate Governance: What Went Wrong?, 52 STAN. L. REV. 1731 (2000). 